\title{
SEX WARS REDUX: AGENCY AND COERCION IN FEMINIST LEGAL THEORY
}

\author{
Kathryn Abrams*
}

What consequences flow from characterizing women as pervasively constructed by male aggression? Over the past decade, dominance feminism $^{1}$ has become the ascendant feminist legal theory, shaping the socially transformative legal claim for sexual harassment ${ }^{2}$ and helping women see the systematic oppression cloaked and perpetuated under the guise of legal neutrality. This same decade, however, has witnessed the emergence and re-emergence of a feminist critique of the dominance approach. Speaking sometimes as stark antagonists, and sometimes as supportive critics, these feminists have questioned the implications of dominance-based depictions for the ways that women are viewed by themselves and by others.

The first challenge to dominance feminism emerged in the "sex wars" of the 1980s. In this effort, a vivid and varied group of feminist scholars and activists challenged the emerging feminist anti-pornography

* Professor of Law, Cornell Law School; Associate Professor of Ethics and Public Life, Cornell University. I am grateful to Lynne Henderson and Steve Shiffrin, who offered wonderful comments on an earlier draft, and to Bill Kell, Henry Shue, and participants at a workshop at Washington College of Law, American University, for thought-provoking conversations about the subject of this Article. Elizabeth Goldberg provided resourceful research assistance, as well as stimulating commentary on women, coercion, and agency. Special thanks to Andrea Cohen for insightful editing as well as patience and flexibility beyond the call of duty.

1. I use the term "dominance feminism" to describe that strand of feminist (legal) theory that locates gender oppression in the sexualized domination of women by men and the eroticization of that dominance through pornography and other elements of popular culture. Catharine MacKinnon is frequently taken to be the paradigmatic dominance feminist, and I shall treat her work as paradigmatic in certain places in this Article. However, by the use of the term I mean to invoke the entire range of feminists who have worked to raise consciousness about male sexualization of, and aggression against, women. In critiquing domimance feminism, many of the academic agency theorists scrutinize not only Mackinnon but other theorists who employ similar premises as well. See infra Part III.B.2.

2. See Meritor Sav. Bank v. Vinson, 477 U.S. 57, 64-67 (1986) (holding employer liable for sex discrimination when it creates hostile environment in which female employees are subject to demeaning sexual abuse, whether or not it results in economic detriment). Catharine MacKinnon's book, Sexual Harassment of Working Women, was the first effort by a legal theorist to characterize sexual harassment as a form of gender discrimination and argue for its legal remediation under Title VII of the 1964 Civil Rights Act. See Catharine A. MacKinnon, Sexual Harassment of Working Women 4-7 (1979) [hereinafter MacKinnon, Working Women]. The basic contours of this understanding were embraced by the lower federal courts in cases like Henson v. City of Dundee, 682 F.2d 897, 901-03 (11th Cir. 1982) and Bundy v. Jackson, 641 F.2d 934, 944-45 (D.C. Cir. 1981), and by the Supreme Court in Vinson, 477 U.S. at 57. MacKinnon also co-wrote the brief for the plaintiff in Vinson. See Brief of Respondent Michelle Vinson, Meritor Sav. Bank v. Vinson, 477 U.S. 57 (1986) (NO-84-1979). 
movement. ${ }^{3}$ They charged that to depict women as shaped by pervasive male sexual coercion was to tell a partial, and potentially injurious, story. ${ }^{4}$ The attack on pornography obscured the sexual pleasure women had been able to achieve, even under oppressive conditions. Its exclusive focus on women's sexual subjugation thwarted an inquiry crucial to the liberatory effort: into the nature of women's sexuality, the largely unexplored content of women's sexual imaginations, and the conditionsimagined or achieved-of women's sexual satisfaction.

After a lull, produced in part by the legal defeat of an Indianapolis anti-pornography ordinance, ${ }^{5}$ two groups of feminists have reanimated the sex wars themes. The first, led by popular essayists Camille Pagha, ${ }^{6}$ Katie Roiphe, 7 and Naomi Wolf, 8 has decried the "victim" status assigned to women by dominance feminism. These writers have warned-often with marked antipathy toward feminist activists-that depictions of women as sexually subordinated encourage a wounded passivity on the part of women and a repressive regulatory urge on the part of state authorities. They have argued for a greater emphasis on women's agency: a program directed not toward the transgressive self-exploration of the sex wars writers, but toward exploiting the sexual, economic, and political power these writers claim women already possess.

A subtler and more sophisticated critique has emerged from feminist academics in the fields of legal, political, and literary theory. ${ }^{9}$ Writing without the antipathy that characterizes the popular work in this vein, these theorists have asked what it means for individual women and female legal claimants for influential feminist theories to present them as defined by male-instigated sexual coercion. Moving beyond the field of

3. The best known and most influential collections of work from this period, from which many of the essays discussed below are taken, are Pleasure and Danger: Exploring Female Sexuality (Carole S. Vance ed., 2d ed. 1992) [hereinafter Pleasure and Danger] and Powers of Desire: The Politics of Sexuality (Ann Snitow et al. eds., 1983) [hereinafter Powers of Desire].

4. See, e.g., Carole S. Vance, Pleasure and Danger: Toward a Politics of Sexuality [hereinafter Vance, Toward a Politics of Sexuality], in Pleasure and Danger, supra note 3, at 1-7 (describing both exclusive pleasure focus and exclusive danger focus as inadequate ways of describing women's sexuality).

5. See American Booksellers Ass'n v. Hudnut, 771 F.2d 323, 332 (7th Cir. 1985), aff'd, 475 U.S. 1001 (1986). The court in Hudnut struck down an Indianapolis ordinance, see Indianapolis, Ind., Code $\$ 16$ (1984), based on the model proposed by Catharine MacKinnon and Andrea Dworkin. For purposes of this Article I will use the Model AntiPornography Civil-Rights Ordinance, in Andrea Dworkin \& Catharine A. MacKinnon, Pornography and Civil Rights: A New Day for Women's Equality 138 (1988) [hereinafter MacKinnon-Dworkin Anti-Pornography Ordinance] as the prototype for the MacKinnonDworkin Anti-Pornography Ordinance. See infra note 56.

6. See Camille Paglia, Sex, Art and American Culture (1992).

7. See Katie Roiphe, The Morning After: Sex, Fear, and Femmism on Campus (1993).

8. See Naomi Wolf, Fire with Fire: The New Female Power and How It Will Change the 21st Century (1993).

9. For a discussion of several exemplary works in this genre, see infra Part 1II.B.2. 
pornography to diverse areas of feminist concern, they have investigated a capacity for self-definition and self-direction which includes but exceeds the sexual agency that was the focus of sex wars writers. Some of these critics have proposed that dominance theorists enrich and complicate their accounts of women's oppression by illuminating the possibilities of women's agency-not the unconstrained agency of a Roiphe or Paglia, but a partial agency consistent with widespread patterns of subordination.

While some commentators have noted the similarities between the sex wars critique of dominance feminism and the critiques emerging today, ${ }^{10}$ none has explored what seem to be equally obvious differencesbetween the critiques themselves, or between the political and legal landscapes in which they operate. Both similarities and differences should be important to feminist legal theorists investigating these questions because the sex wars critique-notwithstanding the legal defeat of the anti-pornography ordinance-did not make a lasting impression on legal theory or doctrine. Observing the similarities between the two critiques may help us to appreciate the difficulties that may confront those who seek to introduce more complex accounts of women's subjectivity under oppression. Appreciating the differences between the two critiques may help us to understand the distinctive resources that contemporary feministsspecifically, proponents of the academic critique-may bring to bear on these difficult questions.

In this Article, I compare these two moments in feminist thought to ask how we might formulate feminist theories that highlight both women's oppression and the possibilities of women's agency ${ }^{11}$ under op-

10. See Tracy E. Higgins, Reconsidering Sexuality in Feminist Theory: "What Do Women Want?" and Why Should Feminists Care? 15-22 (1994) (unpublished manuscript, on file with the Columbia Law Review); Linda C. McClain, Agency, Irresponsibility, and Sexuality: Gender Ideology and Feminist Legal Theory 22 (1994) (unpublished manuscript, on file with the Columbia Law Review); see also Kathryn Abrams, Songs of Innocence and Experience: Dominance Feminism in the University, I03 Yale L.J. 1533-34 (1994) (reviewing Roiphe, supra note 7).

11. Although the term "agency" is generally used to denote something like knowing self-direction, I use it in this essay in a way that acknowledges an internal, as well as an external or outwardly-oriented, aspect to agency, and that highlights the oppressed circumstances of many who seek to exercise it. I use "agency" here to denote the ability to develop and act on conceptions of oneself that are not determined by dominant, oppressive conceptions. Women's agency under oppression is necessarily partial or constrained, because women must contend with-and are not presently capable of completely disarming, either collectively or individually-structures and practices that operate to deny or mitigate that capacity. Women's agency, in the sense I describe it below, is frequently directed toward resisting those structures, practices, or images that contribute to genderbased oppression. For this reason, the term "agency" is frequently coupled with the term "resistance."

In an earlier essay, I employed the term "autonomy." See Abrams, supra note 10, at 1552-57. However, I prefer the term "agency" because it is not so predictahly linked to the strong account of human rationality that has been questioned by some feminist theorists. See, e.g., Susan Bordo, The Flight to Objectivity: Essays on Cartesianism and Culture 101-05 (1987) (arguing that Descartes's innovation was to re-create reason in a masculine 
pression. I then consider some of the legal and political positions to which such a formulation might lead. Part I explores the sex wars, through which some feminists challenged accounts of unmitigated sexual subjugation by insisting on the possibilities of women's sexual exploration and pleasure. Part II examines the reasons why this "sex radical" critique failed to exert a sustained influence on feminist or other legal theory, and why its nascent legal counterpart-the legal advocacy of the Feminist Anti-Censorship Task Force (FACT) ${ }^{12}$-was reductively assimilated to liberal feminism. Part III traces the emergence of a contemporary critique, whose focus has shifted from the possibilities of transgressive, self-directed female sexuality to the possibilities of women's agency and resistance, in realms both sexual and non-sexual. It also assesses the differences between the sex-based and agency-based critiques. Part IV asks how feminist theorists might frame an agency-based critique so as to engage and challenge the assumptions of feminist and other legal theories. It then explores several types of initiatives toward which a theory of partial agency might point, as well as distinctive dangers to which its proponents might be exposed.

\section{The "Sex Wars": Sexuality-Based Challenges to DOMINANCE THEORY}

The term "sex wars"13 describes a heated debate over feminist depictions of women's sexuality that consumed the attention of many theorists and activists during the mid-1980s. By some accounts, the controversy surfaced with a 1982 Barnard College Conference entitled "Toward a

form); Carol Gilligan, In a Different Voice: Psychological Theory and Women's Development (1982) (arguing that priority placed on problem solving through hierarchies of abstract principles may obscure other forms of coguition more frequently associated with women); Genevieve Lloyd, The Man of Reason: "Male" and "Female" in Western Philosophy 49-50 (1984) (arguing that Descartes's thought created categories that led to separation of women and rationality). See generally A Mind of One's Own: Feminist Essays on Reason and Objectivity (Louise M. Antony \& Charlotte Witt eds., 1993) (essays viewing question of relation between rationality and gender from numerous perspectives). The actions of a woman who behaves as an agent must be based on some awareness of and wish to vindicate-her view of herself or her preferences. However, these actions need not be based on reasoned judgments, but may also respond to desires or intuitions that might not be categorized as "rational" in the strong sense.

12. FACT was a group of feminists who organized in 1984 to oppose the Indianapolis anti-pornography ordinance, see Indianapolis, Ind. Code $\$ 16$ (1984). For further discussion, see infra note 56 .

13. Although it is unclear precisely who coined the expression, the term "sex wars" appears to have come into use after the Barnard Conference, Toward a Politics of Sexuality, The Scholar and Feminist Conference at Barnard College (April 24, 1982), often thought to mark the inception of this struggle. Contemporaneous accounts of that conference describe the antagonistic exchanges between anti-pornography and sex radical feminists, and some accuse anti-pornography feminists of trying to create a "sex panic" by highlighting the role of sadomasochism within the sex radical exploration. See Carole S. Vance, Epilogue, in Pleasure and Danger, supra note 3, at 431, 433-36. But these accounts do not appear to use the term "sex wars" to describe that antagonism. 
Politics of Sexuality"14; by other accounts, the catalyzing event was the burgeoning of a feminist anti-pornography movement in 1983 and 1984. ${ }^{15}$ By all accounts, a central subject of controversy was the emergence of what is now referred to as "dominance" feminism: a theory that describes gender oppression as arising from stark inequalities of power realized and expressed through men's sexual coercion of women.

Proponents of dominance feminism stressed the unrecognized pervasiveness of sexualized domination in many venues of women's lives; they also highlighted the role of this domination in shaping social views of women and women's conceptions of themselves. In her 1975 book Against Our Wills: Men, Women and Rape, Susan Brownmiller characterized rape as a widespread and violent effort to assert power and possession over women's bodies. ${ }^{16}$ Catharine MacKinnon's 1979 work, Sexual Harassment of Working Women, identified and described sexual harassment as a practice that not only exploits the economic vulnerability of women, but also perpetuates their construction as sexual objects. ${ }^{17} \mathrm{~A}$ recurring theme in much of the dominance literature was the role of pornography in shaping cultural images of women and defining women's sexuality. Andrea Dworkin's landmark 1987 work, Pornography: Men Possessing Women, offered the paradigmatic form of this indictment, arguing that a vast pornographic industry eroticized relations of dominance and subordina-

14. For a description of the conference, see Diary of a Conference on Sexuality (Hannah Alderfer et al. eds., 1982) (summarizing activities of conference planning committee and outlining proceedings of conference).

15. Both periods are described as plausible starting points in Carole S. Vance, More Danger, More Pleasure: A Decade After the Barnard Sexuality Conference thereinafter Vance, More Danger, More Pleasure], in Pleasure and Danger, supra note 3, at xvi, xxii-xxiv.

16. See Susan Brownmiller, Against Our Wills: Men, Women and Rape (1975).

17. See MacKinnon, Working Women, supra note 2, at 1-25; see also Catharine A. MacKinnon, Toward a Feminist Theory of the State (1989) [bereinafter MacKinnon, Toward a Feminist Theory]; Catharine A. MacKinnon, Feminism Unmodified: Discourses on Life and Law [hereinafter MacKinnon, Feminism Unmodified] (1987). The sex radicals are ambivalent in their treatment of MacKinnon. On the one hand, some writers are at pains to deny her centrality, either to debates over sexuality or to dominance feminism. See, e.g., Vance, More Danger, More Pleasure, supra note 15, at xxiv-xxv (describing Mackinnon as a "relative newcomer to the sex debates" in an essay written in 1992); Alice Echols, The Taming of the Id: Ferninist Sexual Politics 1968-83, in Pleasure and Danger, supra note 3, at 50, $70 \mathrm{n} .48$ (mentioning Mackinnon only briefly in the context of a reference to Adrienne Rich). Yet on the other hand, MacKinnon appears to be very much on the minds of dominance theory's sex radical antagonists, particularly when the subject turns to the regulation of pornography. See Vance, More Danger, More Pleasure, supra note 15, at xxiv-xxxiii (noting centrality in sex wars of debate over MacKinnon-Dworkin Anti-Pornography Ordinance, supra note 5 , and its continuing controversial influence on initiatives such as the 1986 Attorney General's Commission on Pornography). I will treat Mackinnon in this section as representative of dominance feminists, because hers is indisputably the most fully theorized account of the view the sex radicals resisted. Although some of the work I will cite was written after the sex radical critique, I use it as exemplary here because I see it as the best written articulation of the dominance theory that was in circulation at the time the sex radicals wrote. 
tion, normalized devaluation of and violence against women, and helped to construct an aggressive, objectifying male sexuality. ${ }^{18}$

Dominance theory proved controversial not only in identifying sexualized coercion, but also in describing the women who were its targets. The woman subject to male sexual aggression was perpetually beset in a way that defined her almost exclusively by reference to what was done to her. ${ }^{19}$ As MacKinnon noted,

women live in sexual objectification the way fish live in water. Given the statistical realities, all women live all the time under the shadow of the threat of sexual abuse. The question is, what can life as a woman mean, what can sex mean, to targeted survivors in a rape culture?20

As a result of this vision, dominance feminists characterized women's sexuality primarily as the construct of oppressive forces-"defined by men, forced on women, and constitutive of the meaning of gender."21 This view led some to suggest that many expressions of women's sexualityfrom conventional heterosexual desire, to participation in the ritualized practices of sadomasochism, to involvement in butch/femme lesbian relationships-were shaped by present coercion. ${ }^{22}$ Most importantly, dominance theorists made clear that investigating female desire or imagina-

18. See Andrea Dworkin, Pornography: Men Possessing Women (1981). Dworkin's highly publicized lectures on this subject, however, predated the publication of her book. See, e.g., Andrea Dworkin, Pornography and Grief, in Take Back the Night: Women on Pornography 286 (Laura Lederer ed., 1980).

19. See Martha R. Mahoney, Women and Whiteness in Practice and Theory: A Reply to Catharine MacKinnon, 5 Yale J.L. \& Feminism 217, 217 (1993) (describing Mackinnon as "[d] efining gender by what is done to women").

20. MacKinnon, Toward a Feminist Theory, supra note 17, at 149.

21. Id. at 128.

22. MacKinnon, for example, sometimes levels straightforward allegations that such practices reproduce male dominance. See id. at 135 . MacKinnon argues that the sex radicals" division of the "domain of the sexual" into pleasure and danger

parallels the ideological forms through which dominance and submission are eroticized, variously socially coded as heterosexuality's male/female, lesbian culture's butch/femme, and sadomasochism's top/bottom. Speaking in role terms, the one who pleasures in the illusion of freedom and security within the reality of danger is the "girl"; the one who pleasures in the reality of freedom and security within the illusion of danger is the "boy."

Id.; see also id. at 142 ("[t]he relational dynamics of sadomasochism do not even negate the paradigm of male dominance, but conform precisely to it"). At other times MacKinnon offers more nuanced and sympathetic explorations of the ways in which the sexualized dominance that pervades women's lives might influence their tastes and needs. MacKinnon notes:

immense energy goes into defending sexuality as just fine and getting better all the time, and into trying to make sexuality feel all right, the way it is supposed to feel. Women who are compromised, cajoled, pressured, tricked, blackmailed, or outright forced into sex (or pornography) often respond to the unspeakable humiliation, coupled with the sense of having lost some irreplaceable integrity, by claiming that sexuality as their own. Faced with no alternatives, the strategy to acquire self-respect and pride is: I chose it. 
tion-in present or aspirational forms-was a less urgent priority than exposing and halting the aggression that gave such desire its contemporary meaning. In the words of Ti-Grace Atkinson, "I do not know any feminist worthy of that name who, if forced to choose between freedom and sex, would choose sex. She'd choose freedom every time."23

This thesis of strong sexual construction, and the low priority assigned to the exploration of women's pleasure, sparked a heated response from some feminists. These feminists, who referred to themselves as pro-sex feminists or, more frequently, feminist sex radicals, ${ }^{24}$ offered several distinct lines of criticism. First, they argued that the dominance thesis obscured the ambiguity and variety of women's sexual engagements and discouraged more particularized investigation into women's sexual pleasure. As Carole Vance argued, in the introduction to the Barnard Conference collection Pleasure and Danger:

Initially useful as an ideological interruption, [the dominance view] now shares the same undialectical and simplistic focus as [its patriarchal counterpart]. Women's actual sexual experience is more complicated, more difficult to grasp, more unsettling ....

Id. at 149; see also id. at 148-49 (describing as a "particularly devastating and confusing consequence of sexual abuse for women's sexuality" the fact that abuse may feel physically pleasurable or emotionally satisfying).

23. Ti-Grace Atkinson, Why I'm Against S/M Liberation, in Against Sadomasochism: A Radical Feminist Analysis 90, 91 (Robin R. Linden et al. eds., I982).

24. See Vance, More Danger, More Pleasure, supra note I5, at xxii-xxiii (term "sex radical ... does the least violence to their project"). While my general preference is to use names or terms that groups use to refer to themselves, inasmuch as I consider these works primarily to be critiques of dominance feminism and only secondarily as expressions or explorations of transgressive female sexuality, the logic of using these terms is less than transparent. The term "feminist sex radical" does not appear to engage the dominance question at all; instead, it places its full emphasis on the transgressive character of the sexual exploration it effects. This appearance, however, is somewhat misleading. It is a salient part of the sex radicals' critique of dominance feminism that dominance-based suspicion of patriarchally-inflected sex does not bear equally on all women: satisfied heterosexuals, practitioners of $\mathrm{s} / \mathrm{m}$, and butch/femme lesbians may be particular targets. Moreover, in the view of many sex radicals, even less judgmental forms of feminism have failed to incorporate or demarginalize the experience of sexual minorities. So there is some relation between the term "sex radical" and the critique of dominance: those who are sexually radical stand to lose the most if dominance theory and other ascendant forms of femimism are not interrogated from the standpoint of their impact on women's sexuality. "Pro-sex feminism" seems to me more problematic, particularly in its implication (if it is viewed as critique as well as exploration) that those in the dominance camp are antisex. This is an imphication that most dominance feminists strongly dispute. For a useful discussion of why the terms "pro-sex" and "anti-sex" fail to capture the debate over dominance feminism, see Higgins, supra note 10, at I0-I8. The term "pro-sex", however, retains some descriptive value: it highlights the efforts of these feminists to secure a larger place within feminism for affirmative visions of women's sexuality. For these reasons, I will most frequently refer to proponents of the sexuality-based critique of dominance feminism as "sex radicals," though I may occasionally use the terms "pro-sex feminist" or "sex wars critics." See also Vance, More Danger, More Pleasure, supra note 15, at xxiii (concluding that "feminist sex radical" is least misleading term). 
... [T] he rich brew of our experience contains elements of pleasure and oppression, happiness and humiliation. Rather than regard this ambiguity as confusion or false consciousness, we should use it as a source-book to examine how women experience sexual desire, fantasy, and action. ${ }^{25}$

In contrast to dominance feminists' efforts to trace women's sexual subjectivity to their oppressive experience, the sex radicals described an incompletely determined, or multiply determined, female sexuality. This posture made it appropriate, indeed imperative, to examine the nature and the sources of women's sexual desire.

Second, the sex radicals charged that dominance feminism fostered an intolerant attitude toward a range of sexual practices. Efforts to analogize between satisfied heterosexuals, butch/femme lesbians, and practitioners of sadomasochism did more than illuminate male dominance as the motive force behind a range of sexualities. It stigmatized, and implicated in their own oppression, women whose tastes or practices seemed to reproduce dominant patterns. "At this moment," Amber Hollibaugh warned,

we have gone further than just remove experiences and people who don't fit comfortably within our picture of the sexual universe; we have also attempted to slander and quiet those women whose intellectual ideas disagree or challenge the prevailing attitudes in the women's movement about sex....

Who are all the women who ... are the lovers of butch or femme women; who like fucking with men; practice consensual $\mathrm{s} / \mathrm{m}$; feel more like faggots than dykes; love dildoes, penetration, costumes .... Are we creating a political movement that we can no longer belong to if we don't feel our desires fit a model of proper feminist sex?26

The judgmental stance of dominance theorists toward sexuality under present conditions and their comparative silence on the question of affirmative sexual images also risked reanimating Victorian norms that made sex shameful, particularly for women.

Finally, sex radicals argued, the subordination of pleasure to a virtually exclusive focus on identifying and preventing danger deprived women of a resource vital to self-understanding and resistance. The sex radicals asked, in Atkinson's terms, ${ }^{27}$ what women were supposed to do about sex while they were fighting for freedom. A rich and adventurous sexual experience satisfied desires-for self-expression and self-discovery as well as physical pleasure-that could not readily be suspended until the feminist millennium. Moreover, the sex radicals viewed the satisfaction of such needs as integral to, rather than separate from, the feminist

25. Vance, Toward a Politics of Sexuality, supra note 4, at 5-6.

26. Amber Hollibaugh, Desire for the Future: Radical Hope in Passion and Pleasure, in Pleasure and Danger, supra note 3 , at $401,403$.

27. See Atkinson, supra note 23. 
liberatory struggle. "It is not enough to move women away from danger and oppression," as Carole Vance noted:

[1]t is necessary to move toward something: toward pleasure, agency, self-definition. Feminism must increase women's pleasure and joy, not just decrease our misery. It is difficult for political movements to speak for any extended time to the ambiguities, ambivalences, and complexities that underscore human experience. Yet movements remain vital and vigorous to the extent that they are able to tap this wellspring of human experience. Without it, they become dogmatic, dry, compulsive, and ineffective. To persist amid frustrations and obstacles, feminism must reach deeply into women's pleasure and draw on this energy. ${ }^{28}$

A transgressive, exploratory sexual life might, finally, constitute a form of resistance itself, permitting women to experience pleasures that were sanctioned or proscribed under patriarchal social norms.

The sex radicals pursued this exploration in a number of substantive contexts and at varying levels of abstraction. Some writings explored the content and appeal of the sexual taboo; others unearthed the multiple, intersecting meanings of practices such as sadomasochism or butch/ femme lesbianism; still others offered dense, textured accounts of sexuality in particular historical periods, in film, or in the lives of "sexual minorities." ${ }^{29}$ Through this exploration, the authors sought to legitimate a sustained focus on women's sexual pleasure ${ }^{30}$ and to challenge the unacknowledged constraints placed on sexual pleasure by heterosexism, androcentrism, and, importantly, feminism. They also sought to advance new images of women's sexual subjectivity: images that emphasized the

28. Vance, Pleasure and Danger, supra note 3 , at 24.

29. These efforts ranged from the poetry of Sharon Olds, see generally Pleasure and Danger, supra note 3, at 425-30 (including Olds' poems "Sex without Love," "Bestiary," "The Sisters of Sexual Torture," and others); Irena Klepfisz, Powers of Desire, supra note 3, at 228 (including "they're always curious"), to the autobiographical narratives of Joan Nestle and Cherrie Moraga, see Amber Hollibaugh \& Cherrie Moraga, What We're Rollin' Around in Bed With: Sexual Silences in Feminism, in Powers of Desire, supra note 3, at 394; Joan Nestle, My Mother Liked to Fuck, in Powers of Desire, supra note 3, at 468 [hereinafter Nestle, My Mother]; Joan Nestle, The Fem Question, in Pleasure and Danger, supra note 3, at 232 [hereinafter Nestle, The Fem Question], to the historical investigations of Jacquelin Dowd Hall and Ellen DuBois, see Jacquelyn Dowd Hall, "The Mind That Burns in Each Body": Women, Rape, and Racial Violence, in Powers of Desire, supra note 3, at 328; Ellen C. DuBois \& Linda Gordon, Seeking Ecstacy on the Battlefield: Danger and Pleasure in Nineteenth Century Feminist Sexual Thought, in Pleasure and Danger, supra note 3 , at 31 .

30. They strove, in the words of Dorothy Allison, "to organize for our sexual desire as strongly as we have tried to organize for our sexual defense." Dorothy Allison, Public Silence, Private Terror, in Pleasure and Danger, supra note 3 , at 103, 112. This phrase, in fact, represented a part of the agenda of the Lesbian Sex Mafia, an ironically named consciousness-raising group on sexuality that Allison helped to organize in the $1980 \mathrm{~s}$. See id. at 111-12. 1t was not atypical of writers within the sex wars critique to be simultaneously involved in consciousness-raising, activist, or guerilla theatre groups concerned with sexuality. 
self-definition and self-direction in actual lives lived under oppression, ${ }^{31}$ or drew more strongly on imagination or aspiration. ${ }^{32}$

The sex radicals' search for liberatory images of women's sexuality ultimately fueled their final strategy: opposing the regulation of pornography. The dominance-led anti-pornography campaign seemed to many sex radicals to underscore the dangers they had glimpsed in dominance theorizing. The resort to legal regnlation ${ }^{33}$ engaged the state, an institutional actor deeply implicated in women's oppression. This fact made some commentators worry about the wisdom of legal regulation in the context of pornography. As Willis noted:

No pornographer has ever been punished for being a womanhater, but not too long ago information about female sexuality, contraception, and abortion was assumed to be obscene. In a male supremacist society, the only obscenity law that will not be used against women is no law at all. ${ }^{34}$

The interjection of the state also enhanced the social tendency toward sexual censoriousness and control by giving official sanction to the derogation of many sexual practices. ${ }^{35}$ Yet the most disturbing feature of regulation was its conclusive focus on sexual danger: by marking the sexual primarily as a site of oppression, and targeting representations that might otherwise become the objects of investigation, regulation made it more

31. Joan Nestle emphasized strains of self-knowledge and self-direction in the life of her mother-a sometimes ostracized, sometimes abused "working woman who liked to fuck, who believed she had a right to have a penis inside of her if she liked it and who sought deeply for love but knew that was much harder to find." Nestle, My Mother, supra note 29, at 470 .

32. Paula Webster recounted the experience of a consciousness-raising group, whose participants sought to transcend their personal sexual taboos by revealing and describing them. See Paula Webster, The Forbidden: Eroticism and Taboo, in Pleasure and Danger, supra note 3, at 385-87, 390-91, 397 n.4. Amber Hollibaugh described striving toward a life in which sexual exploration was central and uninhibited. See Hollibaugh, supra note 26 , at 401 .

33. Although the early critics of pornography, Women Against Pornography (WAP) and Women Against Violence in Pornography and Media (WAVPM), did not initially advocate legal regulation, the sex radicals anticipated and opposed their ultimate move in that direction. By the time that Pleasure and Danger, supra note 3 , and Powers of Desire, supra note 3, were first published in 1983-84, a version of the MacKinnon-Dworkin AntiPornography Ordinance, supra note 5 , was being considered by the Minneapolis City Council. See Paul Brest \& Ann Vandenberg, Politics, Feminism, and the Constitution: The Anti-Pornography Movement in Minneapolis, 39 Stan. L. Rev. 607, 616-33 (1987) (describing consideration of Ordinance). A substantially similar ordinance was adopted by the City of Indianapolis in 1984. See Indianapolis, Ind., Code $\S 16$ (1984). The Ordinance did not provide for state-initiated criminal prosecutions, but rather for civil claims to be filed with courts or administrative agencies by individual women.

34. Ellen Willis, Feminism, Moralism, and Pornography, in Powers of Desire, supra note 3 , at 466 .

35. Defining pornography "as the eneiny," Ellen Willis argued, "[will] make a lot of women ashamed of their sexual feelings and afraid to be honest about them." Id. at 461 . 
difficult for women to explore ${ }^{36}$ and promulgate new images of female sexuality. ${ }^{37}$

The notion that women had been, and might be, sexual subjectsthe partial authors of their sexual fantasies, and initiators in identifying and satisfying their sexual desires-underlied most of the sex radicals' efforts. ${ }^{38}$ Some authors brought women's sexual agency to the fore: Vance's exhortations to agency ${ }^{39}$ and Nestle's narratives of women who recognized and strove to satisfy their own desires ${ }^{40}$ are salient examples. But most sex radicals were content to leave agency in the background, as an undiscussed enabling condition. The varied, transgressive experience of female sexual pleasure, rather than the agency or self-direction that helped women bring it about, occupied the foreground in this work.

\section{Sex Radicals and the Law}

The sex radicals' critique of dominance feminism palpably influenced feminist activism: it problematized and ultimately diversified a growing focus on regnlating pornography. ${ }^{41}$ Its influence has been less pronounced, however, on legal theory and doctrine. Although the critique mobilized a number of legal feminists, who challenged the Indianapolis anti-pornography ordinance ${ }^{42}$ by establishing the Feminist Anti-

36. Amber Hollibaugh, for example, detailed the effect on her own life of the assumption, implicit in the dominance critique of pornography, of a conclusive link between sexual fantasy and sexual action:

I really believed that if an image rested at the corners of my mind, giving it center stage would inevitably lead to doing it. So, every time I dreamed of fucking fur, not flesh, I was horrified. I worried I might still dream of fucking a man, that I would betray both lesbianism and feminism by dreams of penetration, power and of being overwhelmed. And I panicked when I thought of . . . the multilayered worlds full of desert islands, baby bottles, whips, pleading voices singing for the right to seduce me, winds that whistled between my thighs. Hollibaugh, supra note 26 , at 405 .

37. Sex radicals also charged the anti-pornography movement with endangering sexual minorities-the most frequent targets of regulation-and fostering an ill-conceived alliance between the religious right and the feminist left that would strengthen the hand of ascendant conservatives. See Vance, More Danger, More Pleasure, supra note 15, at xxvii-xxxv.

38. "Can women be sexual actors?" Carole Vance challenged her readers in the introduction to the first edition of Pleasure and Danger. "Can we act on our own behalf? Or are we purely victims, whose efforts must be directed at resisting male depredations...." Vance, Toward a Politics of Sexuality, supra note 4, at 6-7.

39. See supra text accompanying note 25.

40. See supra text accompanying note 31 .

41. The critique has also produced valuable academic consequences: its inquiry into the relationship between sexuality and gender has informed the body of scholarship known as Queer Theory. Works within this field that focus in particular on the relation between gender and sexuality include Judith Butler, Gender Trouble (1990) and Eve K. Sedgwick, The Epistemology of the Closet (1990).

42. See Indianapolis, Ind., Code $\S 16$ (1984). It was held unconstitutional by a federal district court in American Booksellers Ass'n, Inc. v. Hudnut, 598 F. Supp. 1316 (S.D. Ind. 
Censorship Task Force (FACT), ${ }^{43}$ the sex radicals' analysis has not produced a sustained impact on feminist or other legal theory. Unlike equality/difference theory, ${ }^{44}$ it has not generated a framework for legal analysis, and unlike dominance theory, it has not introduced an influential account of gender injury or the female legal subject. Feminist legal theorists, in fact, lave assimilated only fragments of the pro-sex critique, at a time when dominance theory has become an influential feminist legal theory. The factors responsible for this limited impact bear investigation as they may reflect on the transformative potential of more recent critical efforts.

\section{A. The Sex Wars and Legal Theorists}

Both the context and the content of the sexuality-based critique may help to explain its limited influence on legal thought. In the early to mid-1980s, dominance feminism was not a target that was likely to command concerted legal attention. Catharine MacKinnon's work on sexual liarassment brouglit the theory to the world of law; 45 yet that claim had not reached its present prominence and the theory was not widely known outside feminist jurisprudence. ${ }^{46}$ It was also difficult, during this period, to divert legal feminists from the challenges of the equality/difference framework. ${ }^{47}$ Nor was a pro-sex challenge to the anti-pornography move-

1984) and the Seventh Circuit Court of Appeals in American Booksellers Ass'n, Inc. v. Hudnut, 771 F.2d 323 (7th Cir. 1985), aff'd, 475 U.S. 1001 (1986).

43. This effort is discussed infra text accompanying notes $56-74$.

44. I use the term "equality/difference theory" to describe feminist accounts that characterize women's unequal circumstances as arising either from a failure to acknowledge women's similarities to men, or a failure to recognize and accommodate their differences from men. Though these accounts may be regarded as establishing two different theories--one describing women as essentially similar to men and one describing them as essentially different-I group them together here because in their application to law, I see them as creating a single framework, which regards women as generally similar to, but occasionally different from, men (capacity for childbearing being the primary difference). In this view, I follow Catharine MacKinnon's conceptualization in "Difference and Dominance," which describes equality and difference feminisms as being two manifestations of the same conceptual framework, which takes men as the norm and difference as an ontological fact rather than a construct arising from power inequalities. See Catharine A. MacKinnon, Feminism Unmodified, supra note 17, at 32, 33. I locate the theory of women's partial agency that I describe infra at Part IV as being on domimance theory's continuum between coercion and complete agency, rather than within the equality/difference framework.

45. See generally MacKinnon, Working Women, supra note 2 (conceptualizing sexual harassment as a form of sex discrimination or denial of equal employment opportunity actionable under Title VII of the 1964 Civil Rights Act).

46. MacKinnon's efforts to enact anti-pornography ordinances that were grounded in her theory of sexualized dominance had, of course, attracted more widespread legal attention. The relation between the sex radical critique and legal efforts to respond to the Indianapolis anti-pornography ordinance, Indianapolis, Ind., Code $\S 16$ (1984), is discussed infra Part II.B.

47. Although the challenges of the equality/difference framework, such as the debate over the accommodation of pregnancy, consumed the attention of most legal feminists 
ment a promising way to engage broad legal attention. Schooled by recent experience with obscenity prosecutions, legal theorists had developed a distinctive way of challenging such regulation-via the First Amendment ${ }^{48}$ - which spared them the discomfort of a direct confrontation with sexuality.

Perhaps a more important explanation for the sex radicals' failure to influence legal theory is that the sex radicals were not lawyers; they were activists, anthropologists, journalists, historians, and poets. They neither pretended nor aspired to a sophisticated understanding of the operation of the legal system. As a result, their work was less widely read by legal theorists than it might have been had they been writing from within the discipline or publishing in legal periodicals. Moreover, even when their work was read by legal scholars, it did not seem to translate readily into legal theory or provide accessible answers to legal questions. The sex radicals' work addressed legal issues in ways that may have seemed anomalous, in that it failed to coincide with the assumptions or ways of framing central questions that were most familiar to legal theorists.

For example, the sex wars critique reflected an odd coupling of a goal which could not be implemented by direct legal prescription and a thin account of the more indirect ways in which law might shape social norms. The sex radicals' object-the discovery and iteration of a complex and highly individuated women's sexuality - was not one that was likely to be implemented by direct legal effort. The enormous variability of sexual pleasure and its status as an affirmative good, rather than an injury to be prevented, made it difficult to imagine (and indeed the sex radicals did not consider) how it could be programmatically promoted by legislative or judicial officials. ${ }^{49}$ It remained possible that prospective reformers might glimpse ways in which law could affect sexual norms less

during the period that non-legal feminists were engaging in the sex wars, MacKinnon did ultimately divert the attention of legal feminists from the equality/difference framework. By the late 1980s, legal feminists were becoming increasingly aware-and in some cases, increasingly critical-of her work. See, e.g., Katharine T. Bartlett, MacKinnon's Feminism: Power on Whose Terms?, 75 Cal. L. Rev. 1559 (1987) (book review criticizing Mackinnon for pejorative inages of woinen and for assuming exclusive power to define appropriate women's perspective formerly held by inen); The 1984 James McCormick Mitchell Lecture, Feminist Discourse, Moral Values and the Law-A Conversation, 34 Buff. L. Rev. 11, 75 (1985) (critique of MacKinnon's theory by Mary Dunlap for subordinating women "to a definition of who is radical, who is feminist, what sex is good and who gets to talk").

48. See, e.g., Thomas I. Emerson, Pornography and the First Amendment: A Reply to Professor MacKinnon, 3 Yale L. \& Pol'y Rev. 130 (1984).

49. Tracy Higgins argues that " $[t]$ he task of the law is to set the boundaries of legally appropriate sexual conduct, proscribing the 'bad' without (directly) prescribing the 'good." "See Higgins, supra note 10, at 12. She argues that this "logic of the law" (one might add, the law under liberal assumptions about the role of the state), contributed to MacKinnon's "eclipse" of the sex radical theory in law: MacKinnon's theory, unlike that of the sex radicals, translated readily into proposals for legal regulation of sexually oppressive (i.e., harmful) practices. See id. at 12-13. 
directly, yet the exploration of this prospect was deterred by the sex radicals' limited account of the ways in which law influenced social norms.

The sex radicals examined law primarily through the lens of the antipornography campaign; neither this subject matter, nor their approach to it, suggested the numerous ways in which law might sbape social understandings and expectations. ${ }^{50}$ In the context of anti-pornography regulation, the social impact that the law achieved flowed directly from its prohibitory power: by authorizing private lawsuits against the creators, sellers, distributors, or users of pornographic materials, it would deter the investigation and proliferation of images that might contribute to women's sexual subjectivity.

The sex radicals also described anti-pornography laws as invigorating censorious views of women's sexuality-a view suggesting legal influence on social norms that did not derive directly from the law's prohibitions. But this premise was neither fully nor consistently elaborated in the sex radicals' work. For some, the fear of reanimating Victorian censoriousness seemed to stem from alliances feminists forged with political conservatives in order to support the legislation. ${ }^{51}$ Others viewed that censoriousness as arising from public confusion of (neo-Victorian) moral and (feminist) political critiques of sexuality. ${ }^{52}$ Thus, the sex radicals seemed to hint at a multi-faceted account of social construction by law, a view that traced law's social impact to the political alliances forged to enact it, to observers' (mis)interpretation of its meaning, and to its specific prohibitions. But this view was never brought to the foreground or made explicit in the sex radical critique. What was foregrounded in the sex radicals'

50. This strategy is not, moreover, a quirk of the pornography context; in one of the few other legal contexts addressed by sex radicals-that of abortion-non-regulation is also prescribed as a means of avoiding censorious control of women's sexual activity. See Brett Harvey, No More Nice Girls, in Pleasure and Danger, supra note 3, at 204-09.

51. Cf. Allison, supra note 30, at 108-09 (describing "hard bargains" feminists have felt compelled to make to accomplish their goals). One "hard bargain" to which Allison was presumably referring was the decision by supporters of pornography regulation to encourage the alliance, or at least accept the support of, anti-obscenity partisans of the Right. See Vance, More Danger, More Pleasure, supra note 15, at xxix-xxxi (describing anti-pornography, anti-obscenity coalition culminating in work of 1986 Attorney General's Commission on Pornography). MacKinnon disputes the notion that anti-pornography feminists have cultivated such alliances, and also contends that anti-obscenity forces can tell the difference between their regulation and feminist regulation and are generally reluctant to support the latter. See MacKinnon, Feminism Unmodified, supra note 17, at 209 (arguing that groups of the religious right do not support, but rather oppose, the MacKinnon-Dworkin Anti-Pornography Ordinance, often on First Amendment grounds).

52. Ellen Willis notes:

[T] he anti-porn campaign ... has begun to attract women whose perspective on other matters is in no way feminist (' 1 'm anti-abortion,' a participant in WAP's [Women Against Pornography's] march on Times Square told a reporter, 'but this is something I can get into'). Despite the insistence of WAP organizers that they support sexual freedom, their line appeals to the anti-sexual emotions that feed the backlash.

Willis, supra note 34 , at 467 . 
arguments was a surprisingly laissez-faire approach-avoid legal encumbrance, and women may interrogate and re-imagine their sexuality-and a limited and limiting assumption that the law's most noteworthy social effects are achieved through prohibition. This traditional assumption may have seemed particularly anomalous when combined with the radical nature of the subject matter. Those legal readers prepared to accept this view of law's social effect may have been put off by the subject matter of the critique, while those engaged by questions of coercion and sexuality may have concluded that there was little to interest them, as legal thinkers, in so minimalist a legal theory.

Legal theorists may also have been puzzled by a second feature of the sex radicals' presentation: their ambiguous depiction of women as legal subjects. The sex radicals rejected the female subject of dominance theory, who was wholly constructed by male domination. Most also dismissed the fully self-determining subject of liberal theory, being too aware of the constitutive effects of oppression on women. Yet the sex radicals were not clear about what sort of subject might emerge from the area between these two poles and how much control and direction she would exercise over her life. Differences of opinion among the sex radicals themselves contributed to ambiguity or inconclusiveness on this question. Some authors emphasized the effects of sexist, heterosexist, or even feminist constraints on individual sexual lives. ${ }^{53}$ Others treated male dominance as a general landscape against which women worked selfdirectedly toward their own satisfaction. ${ }^{54}$ More importantly, the nature of women's agency under oppression was sufficiently submerged in this work that, beyond the rejection of the polar extremes, it was hard to infer any firm conclusions about women as agents in the social or legal world. Few of the sex radicals, for example, explored or juxtaposed the extent of self-direction and constraint in particular women's lives.

These difficulties were amplified by the difference in disciplinary starting points between the sex radicals and their potential legal audience. The sex radicals, quite reasonably, had little familiarity with the characteristics of the traditional legal subject, i.e., the autonomous selfdirection that tended to be assumed in subjects before the law, or the extreme constraint that served to justify the rare exceptions to this liberal premise. ${ }^{55}$ The result was that their writings depicted a female subject

53. Dorothy Allison's narration of a phone conversation between herself and an anonymous woman who was both driven and terrified by her unconventional sexual desires is a particularly poignant evocation of the strength and variety of these constraints. See Allison, supra note 30 , at $103-05$.

54. See, e.g., Muriel Dimen, Politically Correct? Politically Incorrect?, in Pleasure and Danger, supra note 3, at 138-48; Webster, supra note 32, at 385-98.

55. The autonomous will or capacity for self-direction that inheres in the traditional legal subject has been illuminated by commentators in different ways. Jennifer Nedelsky has critiqued the tendency of a legal tradition informed by liberal political theory to treat "autonomy as a static human characteristic to be posited as a presupposition." Jennifer Nedelsky, Law, Boundaries and the Bounded Self, 30 Representations 162, 168 (1990). 
Nedelsky argues, instead, that autonomy should be viewed as a "capacity that must be developed; it can flourish or it can become moribund." Id. That capacity is developed through human relationships, whose cultivation requires that we reject metaphors of human boundedness, in favor of those that represent "the combination of individuality and 'endmeshedness,' integrity and integration that constitutes the human being." Id. at 182.

James Boyle cites the legal assumption of autonomous will as a legacy of "classical [prerealist] legal thought." James Boyle, Is Subjectivity Possible? The Postmodern Subject in Legal Theory, 62 U. Colo. L. Rev. 489, 511-13 \& n.60 (1991). Under the classical framework, most characteristics of the legal subject that would affect his ability to direct his course in the world-e.g., race, class, gender, and situationally-restricted bargaining power-were simply excluded from legal attention. Boyle explains that a worker, as a legal subject,

[is] formally equal to the legal subject of the corporation with which he negotiates. As the Court in Lochner [Lochner v. New York, 198 U.S. 45 (1905)] put it, bakers are not "wards of the state." The only disabilities which can be recognized in the subject are those which affect the exercise of the will-narrowly conceived to mean the capacity to make calculations of means-ends rationality within the existing "inequalities of fortune."

Id. at 513-14. The realist critique resulted in the decision to "allow some more features of the subject inside the charmed circle of the law." Id. at 516. But the influence of classical legal thought continues in the tendency of recent Court decisions to "conjure[] up the world of a formally equal race-less, class-less subject[ ]." Id.

As the "wards of the state" locution suggests, there is a category of subjects who lack the attributes of the traditional legal subject and some amount of discussion within classical and post-classical legal thought is devoted to identifying them. Yet, as one classification, which identified these non-traditional subjects as "abnormal human beings, such as idiots; . . . animals; . . . inanimate objects . . . [and] juristic persons" suggests, John C. Gray, The Nature and Sources of the Law 27-28 (2d ed. 1921), it is not easy, or uncontroversially beneficial, for a person whose capacity for self-direction is restricted by the social consequences of characteristics such as race, class, or gender to bring herself within this exceptional category.

Anne Coughlin, who focuses primarily on the criminal law, offers a slightly different account. Here, she argues, the inclusion of a capacity for self-direction in the definition of a "responsible actor" - the legal subject on whom punishment can be imposed-follows from the goals of punishment. See Anne M. Coughlin, Excusing Women, 82 Cal. L. Rev. 1, 9-11 (1994). She quotes Paul Robiuson: "Free will is an essential prerequisite to criminal liability' because each of the theories supporting punishment 'depends on men who are capable of choosing how they will behave.' " Id. at 10 n.32 (quoting 1 Paul Robinson, Criminal Law Defenses $91 \mathrm{n.2}$ (1984)). In consequence, Coughlin argues,

Virtually all scholars agree that the responsible actor contemplated by the criminal law is a rational character capable of choosing for himself among alternative courses of action for good or evil. Not surprisingly, these critics also agree that the criminal law must reject a hard determinist account of human action, which holds that conduct and even "human ... willings" are the product of causal factors that the actor did not himself choose.

Id. at 10-1I (footnotes omitted). Because the appropriateness of criminal sanctions hangs on the quality of the fit, there is, understandably, more debate in the criminal context over whether a given defendant falls withm this legal category. The possibility of excuse is "extended to an actor who suffers from a 'disability' that sets him apart from normal actors in a way that makes us doubt that his actions, though a violation of the criminal law, warrant punishment." Id. at 14 (footnotes omitted). However, the scope of excuse in criminal law has historically been narrowly confined, implying "that virtually all actors are capable of rational choice," as well as "guarantee[ing] many beneficial consequences for 
who did not precisely coincide with assumptions of the liberal legal subject, but who was not sufficiently well-defined-particularly in relation to these assumptions-to challenge them.

\section{B. The Feminist Anti-Censorship Task Force}

The distance of the sex radicals from the premises of legal scholarship was not, however, their only source of difficulty. The perplexity their ideas engendered-even when reformulated in legal terms-is demonstrated by a second drama of the sex wars period: the intervention of the Feminist Anti-Censorship Taskforce (FACT) in the legal struggle over the regulation of pornography.

FACT was a group of feminist activists, artists, and writers who mobilized in 1984 to oppose dominance-based anti-pornography laws. ${ }^{56}$ The

the guilty accused, for persons contemplating violations of the criminal law, and for lawabiding actors." Id. at 16.

Coughlin notes that feminist lawyers and scholars "seem unimpressed with the theoretical claims made ... on behalf of the responsible actor," and consequently they readily raise excuse on behalf of battered women who assault or kill, unconvinced that women will be harmed by a finding of irresponsibility. Id. at 23. Coughlin finds this practice questionable because of its intersection with a longstanding exception to the model responsible actor assumption. She observes that women as defendants have not been assumed to be responsible actors in that they have been viewed as subject to what she calls "marital coercion." Id. at 29. A married woman who committed a crime in the presence of her husband was, until recently, "entitled to the presumption that she had acted under his coercion and, therefore, ... could not be held personally responsible." Id. at 31. This suggests that in the criminal context, married women, at least, were considered to be within the category of beings, such as those enumerated by John C. Gray, supra, to whom the usual assumptions did not apply.

56. FACT describes itself as "a group of women long active in the feminist movement who organized in 1984 to oppose the enactment of Indianapolis-style anti-pornography laws. Brief Amici Curiae of Feminist Anti-Censorship Task Force, et al. at xiii, American Booksellers Ass'n v. Hudnut, 77I F.2d 323 (7th Cir. 1985) (No. 84-3I47), reprinted in 21 U. Mich. J.L. Ref. 76 (1987-88) [hereinafter FACT Brief].

The MacKinnon-Dworkin Anti-Pornography Ordinance, supra note 5, in all its various incarnations, creates a legal framework which contrasts starkly with the framework for regulating obscenity, not only in its definition of the material to be regulated, but in the role that it prescribed for the state. The claim created by the ordinance is a civil claim for violation of civil rights, rather than a criminal action. It is initiated not by the state acting in a prosecutorial role, but by individual women or groups of women who claim that they have been injured by the creation or distribution of pornographic representations. The ordinance provides a forum for such claims, but does not intervene to award relief unless there has been a finding that the material in question constitutes:

the graphic sexually explicit subordination of women through pictures and/or words that also includes one or more of the following:

a. women are presented dehumanized as sexual objects, things or commodities; or

b. women are presented as sexual objects who enjoy humiliation or pain; or

c. women are presented as sexual objects experiencing sexual pleasure in rape, incest, or other sexual assault; or

d. women are presented as sexual objects tied up or cut up or mutilated or bruised or physically hurt; or 
group's most complete written statement, an amicus brief ${ }^{57}$ filed by Nan Hunter and Sylvia Law in American Booksellers Association v. Hudnut, ${ }^{58}$ bears an interesting relationship to the sex wars critique. The Brief was animated by many of the concerns that inspired the sex radicals: not only did FACT arise from the anti-regulation activism in which sex radicals played a leading part, but the Brief itself quotes passages from Powers of Desire and other sex wars writings. ${ }^{59}$ Yet FACT sought to place that critique within the existing legal framework so that it could be successfully deployed against the Indianapolis anti-pornography ordinance. ${ }^{60}$ This goal was accomplished in several ways.

The first was to incorporate a First Amendment argument, which was consistent with the anti-interventionist spirit of, but had not specifically been included in, the sex radical critique. This argument emphasized the intolerable vagueness of the ordinance's terms; it underscored the constitutional preference for "more speech" solutions and their plausibility in the context of women's subordination. ${ }^{61}$ It also described sexual speech as importantly political in that it depicts relationships between

e. women are presented in postures or positions of sexual submission, servility, or display; or

f. women's body parts-including but not limited to vaginas, breasts, or buttocks-are exhibited such that women are reduced to those parts; or

g. women are presented as being penetrated by objects or animals; or

h. women are presented in scenarios of degradation, humiliation, injury, torture, shown as filthy or inferior, bleeding, bruised or hurt in a context that makes these conditions sexual.

Dworkin-MacKinnon Anti-Pornography Ordinance $\S 2(1)$, supra note 5, at 138-39. Women seeking relief under the statute may have recourse to five causes of action:

1. Coercion into pormography. It is sex discrimination to coerce, intimidate, or fraudulently induce (hereafter, "coerce") any person into performing for pornography ....

2. Forcing pornography on a person. It is sex discrimination to force pornography on a person in any place of employment, education, home, or any public place

$\ldots$...

3. Assault or physical attack due to pornography. It is sex discrimination to assault, physically attack, or injure any person in a way that is directly caused by specific pornography ....

4. Defamation through pornography. It is sex discrimination to defame any person through the unauthorized use in pornography of their proper name, image, and/ or recognizable personal likeness ....

5. Trafficking in pornography. It is sex discrimination to produce, sell, exhibit, or distribute pornography, including through private clubs ....

Id. $\S 3$, at $139-40$.

57. See FACT Brief, supra note 56.

58. 711 F.2d 323. Hudnut was the first fully-adjudicated legal challenge to the MacKinnon-Dworkin Anti-Pornography Ordinance, supra note 5. The Hudnut court struck down the Ordinance as a violation of the First Amendment.

59. See FACT Brief, supra note 56, at 121 .

60. Indianapolis, Ind., Code $\$ 16$ (1984). See Pleasure and Danger, supra note 3.

61. See FACT Brief, supra note 56, at 106-22 (argning that "more speech" solutions were preferable to restrictive and unconstitutional vagueness of ordinance's terms, in order to persuade Seventh Circuit to strike down Indianapolis, Ind., Code \$ 16 (1984)). 
men and women that have critical bearing on "the structure of social and political life. ${ }^{n 2}$

More importantly, however, the authors of the FACT Brief sought to revise or resituate those elements of the sex radical critique that made it anomalous or unfamiliar to legal scholars. First, the authors sought to describe the Indianapolis ordinance as a force whose social effects extended beyond those produced by its specific prohibitions. This claim rested largely on the argument that the ordinance perpetuates stereotypes that create a "sexual double standard." 63 The ordinance, Hunter and Law argued, characterizes men as "irresponsible beasts" and women as passive beings who "could not seek or enjoy sex." 64 Not only do these stereotypes reinforce neo-Victorian social understandings, but they also render invisible women with active sexual desires and imaginations and men who treat women with respect. These stereotypes, like those perpetuated by earlier "protective legislation," also restrict women's opportunities in ways that make them less able to protect themselves in the marketplace. ${ }^{65}$

Second, Hunter and Law sought to describe a female subject in terms that would be more accessible to a legal audience by highlighting the questions of agency that had remained a subtext in the sex radicals' work. Their account contained strains of the ambiguity or complexity that characterized the sex radicals' female subjects. The Brief noted that "[w]omen were, and continue to be, in a position of social and economic vulnerability that inhibits their ability to negotiate fair terms and conditions of wage labor ... [and] enter into sexual or other relationships on a free and voluntary basis," 66 and contended, promisingly, that "[b]oth free agency and response to external pressure are simultaneous aspects of human action." ${ }^{67}$ Yet these themes were articulated within a framework that more strongly invoked the freely choosing liberal subject. Toward the conclusion of the Brief, the authors noted:

To resist forced sex and violence, women need the material resources to enable them to reject jobs or marriages in which they are abused or assaulted and the internal and collective strength to fight the conditions of abuse. The ordinance does nothing to enhance the concrete economic and social power of women. Further, its stereotype of women as powerless victims undermines women's ability to act affirmatively to protect themselves. ${ }^{68}$

That day on which women can reject jobs or marriages freely has not, in FACT's view, yet arrived; but it is not so distant as to seem unintel-

62. FACT Brief, supra note 56 , at 120 .

63. Id. at 103-05.

64. Id. at 126-27.

65. Id. at 131-32.

66. Id. at 131 .

67. Id.

68. Id. at 134. 
ligible. ${ }^{69}$ Women need programs that enhance their market or social power, rather than perpetuating damaging stereotypes; with such assistance, they may navigate the economic or social marketplace as self-determining agents. The female subject, in this view, sounds less like the subject constructed by gender-based oppression than like the individual, formed prior to oppression or any other social force, whose path has been impeded by it.

The FACT Brief achieved success in the context of the anti-pornography struggle. The Indianapolis ordinance was struck down as a violation of the First Amendment; ${ }^{70}$ moreover, FACT's account of the political centrality of sexual speech was broadly endorsed by Judge Frank Easterbrook.71 FACT had less success, however, in introducing into legal thought the view of women's subjectivity and circumstances that it shared with the sex radicals. Instead of being perceived as a new account of women's capacity for self-direction under oppression, or of the centrality of sexual exploration to women's present well-being, FACT's position has been widely, and somewhat reductively, characterized as a version of liberal feminism. ${ }^{72}$ To many commentators, the FACT Brief suggested that women should be treated as the self-directing, potentially self-sufficient human beings that they are. Sexual self-expression was, according to this interpretation, simply one thing that women might choose for themselves as their path became less impeded. The illuminating tension between the woman as marketplace actor and the woman as constructed by stereotypic images, and the centrality of sexuality to women's self-conception, were largely eclipsed in this interpretive view.

69. Compare this posture with MacKinnon's view, articulated in relation to the regulation of pornography:

If this proposal were to become law and if it were to be used, if it were to be given the life in women's hands for which it is desigued, there could come a day when she would speak in her own voice and you would hear her. And I think only then would we understand how unimaginable what she would say be for us now.

Catharine A. MacKinnon, Pornography, Civil Rights, and Speech, 1984 Francis Biddle Memorial Lecture at Harvard Law School (April 5, 1984), in 20 Harv. C.R.-C.L. L. Rev. 1, 70 (1985).

70. See American Booksellers Ass'n v. Hudnut, 771 F.2d 323, 332-34 (7th Cir. 1985), aff'd, 475 U.S. $100 \mathrm{I}$ (1976); supra note 58.

71. See Hudnut, 771 F.2d at 331 (sexual speech "influences social relations and politics on a grand scale" and "controls attitudes at home and in the legislature").

72. See Jane E. Larson, "Women Understand So Little, They Call My Good Nature 'Deceit' ": A Feminist Rethinking of Seduction, 93 Colum. L. Rev. 374, 433 n.253 (1993) (citing FACT Brief as example of "liberal goal [of allowing] women to participate as men do by loosening the traditional legal and social controls on women's sexual expression"); see also Richard Delgado \& Jean Stefancic, Pornography and Harm to Women: "No Empirical Evidence?", 53 Ohio St. L.J. 1037, 1046 (1992) (describing FACT as charging Ordinance with "violat[ing] freedom of choice" and "reinforc[ing] the [sexual] double standard"); Lillian R. BeVier, Introduction to Symposium on Pornography, 21 U. Mich. J.L. Ref. 1, 3 (I987-88) (describing FACT Brief as being concerned with ordinance's "violat[ion of] the constitutional guarantee of sex-based equality"). 
This interpretation may be ascribed in part to FACT's own strategic choices. Salient elements of the FACT Brief seem to court this assimilation of a complex view to liberal feminism. Its argument about stereotypes is not a comprehensive account of the varied social effects of the law but a focused claim drawn directly from Equal Protection doctrine in which stereotypes operate as an impediment to the rational perception of women's similarity to men. ${ }^{73}$ The description of women's circumstances discussed above, moreover, reflects more than a nod to the dominant account of the liberal legal subject. Yet if the Brief's authors, in search of legal victory, gave readers the choice of construing their depictions in a liberal vein, they also included descriptive elements that did not conform to liberal expectations. ${ }^{74}$ The neglect of these elements highlights not only the strategic compromises sometimes undertaken by litigators, but also the tenacity of the assumptions held by FACT's readers. Their difficulty perceiving the Brief's descriptive complexity against the backdrop of a liberal legal framework bespeaks the tendency to read the unfamiliar in light of the familiar and the homogenizing, distorting force of dominant legal conceptions.

\section{Sex Wars Redux}

After almost a decade of quiescence, during which time dominance feminism gained considerable influence yet failed to produce legally sustainable anti-pornography regulation, some feminists have again begun to question its vision of women's lives. This questioning, however, differs in salient respects from the sex radical challenges. In the earlier analyses, dominance-based depictions threatened a celebratory, exploratory focus on women's sexual pleasure; in the more recent critique, they threaten the possibility of women's self-definition and self-direction, in matters sexual and otherwise. The shift in emphasis toward what I will refer to as agency is not altogether new; rather, it reflects a sharpening, or foregrounding, of a concern that was an undercurrent of the earlier critique. Several developments served to bring this element to the fore and extend its scope beyond the realm of sexuality. Detailing a few of the most prominent may help to explain the emphasis of the emerging critique.

\section{A. Dominance and Agency}

During the late 1980s and early 1990s, dominance theory gained prominence as an explanation of and response to women's oppression.

73. For an excellent discussion of now-Justice Ginsburg's contribution to this line of argument, see David Cole, Strategies of Difference: Litigating for Women's Rights in a Men's World, 2 Law \& Ineq. J. 3, 53-85 (1984).

74. Their account of women's constraint, of the peculiar mixture of self-direction and constraint that characterizes all human action, and of the debilitating consequences of legally induced stereotypes all pointed to a more complex juxtaposition of pre-social nature and social construction than a straightforward liberal view allowed. 
Judicial recognition of a claim for sexual harassment brought to the law a dominance-based account of sexualized injury. ${ }^{75}$ A largely undiscussed legal doctrine became a household word with the confirmation hearings of Clarence Thomas: aided by a media teach-in, viewers began to glimpse the coercion implicit in sexualized conduct in the workplace and its intersection with other disadvantages suffered by women. ${ }^{76}$ The growing visibility of battered women's self-defense also reflected the contributions of dominance theory. Exposition of a "battered women's syndrome" and of the phenomenon of "learned helplessness" highlighted the unrecognized prevalence of spousal abuse, as well as other factors, such as economic disempowerment, that confined women to coercive relationships. ${ }^{77} \mathrm{Col}-$ lege campuses provided a third arena in which dominance-based accounts gained influence. Mobilizing to resist acquaintance rape and sexual harassment in the university setting, women's groups, peer counselors, and university-sponsored education programs began to draw on theories emphasizing the sexual victimization of women. ${ }^{78}$ Dominance theory also gained a pivotal spokesperson in Catharine MacKinnon, ${ }^{79}$ whose dazzling exposition of dominance feminism and controversial public activism on the issues of sexual harassment and pornography made the theory increasingly visible to non-feminists and non-lawyers.

As dominance theory became more visible, some feminists began to question the images it used to depict women. One central concern was that its emphasis on women's sexual victimization obscured the extent to

75. See Meritor Sav. Bank v. Vinson, 477 U.S. 57, 57 (1986); supra note 2.

76. See Bo Emerson, Lessons from the Hill: What Have We Learned A Year After the Thomas Hearings, Atlanta Const., Oct. 5, 1992, at C1 (hearings "taught America that sexual harassment exists" and "represented a watershed moment in the politics of gender"); Jane Gross, Suffering in Silence No More: Fighting Sexual Harassment, N.Y. Times, July 13, 1992, at A1 (hearings' "nationally televised colloquium on sexual harassment" changed American attitudes toward sexual harassment and "marked a watershed in America's bewildering war between the sexes") Poll: More Awareness of Sexual Harassment, Wash. Post, Dec. 18, 1992, at A8 ("public agreement on what constitutes sexual harassment and awareness of its prevalence ... have grown significantly over the past year"); Jill Smolowe, Anita Hill's Legacy, Time, Oct. 19, 1992, at 56 ("sensitivity to sexual harassment has deepened" as a result of Hill-Thomas hearings).

77. Lenore E. Walker describes this element of consciousness-raising in battered women's self-defense work in A Response to Elizabeth M. Schneider's Describing and Changing: Women's Self-Defense Work and the Problem of Expert Testimony on Battering, 9 Women's Rts. L. Rep. 223, 223-25 (1986).

78. Among the works that have documented and contributed to this pattern are Acquaintance Rape: The Hidden Crime (Andrea Parrot \& Laurie Bechhofer eds., 1991); Ivory Power: Sexual Harassment on Campus (Michele A. Paludi ed., 1990); Robin Warshaw, I Never Called It Rape (1985). Roiphe describes these developments in a critical vein. See Roiphe, supra note 7, at 8-28.

79. Catharine MacKinnon was, of course, a published theorist and well-known activist at the time of the sex wars. However, the publication of two of her best-known works, Feminism Unmodified, supra note 17, and Toward a Feminist Theory, supra note 17, and the visibility of her efforts on behalf of the MacKinnon-Dworkin Anti-Pornography Ordinance, have, in recent years, made her the most familiar proponent of dominance feminism as well as its most sophisticated theorist. 
which women made choices, resisted coercion, and exercised agency in their own lives. This concern recalled the objections of the sex radicals almost a decade earlier; but as dominance theorists and allied practitioners addressed a wider variety of substantial issues, the critics' focus moved beyond sexuality and pleasure to other areas of women's self-direction. ${ }^{80}$

The tension between dominance-based depictions and women's agency may have been amplified by the liberal backdrop that informed "second-wave" feminism and civil-rights-based reform more generally. ${ }^{81}$ Liberalism, as applied in these contexts, posited a subject whose humanity consisted in her theoretically unlimited potential, and her capacity to exercise meaningful choice in the direction of her own life. Reformers influenced by this vision sought to win the full panoply of rights for those, including people of color and women, who share in these characteristics. From this vantage point, the female subject of dominance theory seemed particularly anomalous. The thoroughgoing social constructivism of this theory was startling to sensibilities shaped by liberalism: that one's subjectivity-from one's mode of self-presentation to one's sexual tastescould be so thoroughly shaped by social influences flew in the face of the usual assumptions of autonomous self-determination. And the fact that this constructivism applied so uniquely-and detrimentally-to women seemed to mark them as distinctively impaired.

Yet the growing concern that the female subject of dominance theory seemed inhumanly passive, or acted-upon, did not stem entirely from the liberal standpoint of its observers. This impression also arose from the choices of dominance theorists and of those who applied their work. Eager, perhaps, to confront the assumptions of unimpaired agency that impeded recognition of women's oppression, theorists emphasized the systematic character of women's constraint, or the way that choices sub-

80. It might also be possible to describe this change as a movement of the focus away from pleasure. This movement may be attributable in part to a broadening of the critique's substantive terrain: in areas such as rape or spousal abuse, women's pleasure is neither a relevant concern nor an index of resistance, as it might be in the area of pornographic sexual representation. A movement away from a pleasure focus may also be an incident of the waning of the "sexual revolution." This movement of the late 1960s and early 1970s powerfully influenced the sex radicals, though they were sometimes critical of what they saw as its androcentric focus. Temporal distance from that period, as well as growing social conservatism and the sexual fears produced by AIDS, may make sexuality a less urgent focus, even for feminist theorists. (It is interesting, in this regard, that Katie Roiphe invokes the spirit of the sexual revolution-a revolution she never experienced firsthand-in order to reinvigorate a contemporary version of the sex wars critique. See Roiphe, supra note 7, at 5-7, 12-15, 83-84). However, as the following discussion should make clear, my own sense is that the shift in the contemporary critique is not so much a shift away from sexuality as a move to combine an emphasis on sexual agency with an emphasis on agency in other spheres of women's lives.

81. For critical descriptions of the liberal premises of the "second wave" feminist and civil rights movernents, see MacKinnon, Feminism Unmodified, supra note 17, at 34-40 (feminism); Kimberlé W. Crenshaw, Race, Reform and Retrenchment: Transformation and Legitimation in Antidiscrimination Law, 101 Harv. L. Rev. I331, 1356-66 (1988) (civil rights movement). 
jectively experienced as free may reflect women's collusion in their own subordination. Mackinnon's work provides an example,

Recall that more than one-third of all girls experience sex, perhaps are sexually initiated, under conditions that even this society recognizes are forced or at least unequal. Perhaps they learn this process of sexualized dominance as sex. Top-down relations feel sexual. Is sexuality throughout life then ever not on some level a reenactment of, a response to, that backdrop? .. . Sexually abused women - most women - seem to become either sexually disciplined or compulsively promiscuous or both in series, trying to avoid the painful events, or repeating them over and over almost addictively, or both, in an attempt to reacquire a sense of control or to make them come out right. Women also widely experience sexuality as a means to male approval; ... Violation can be sustained, even sought out, to this end. Sex can, then, be a means of trying to feel alive by redoing what has made one feel dead, of expressing a denigrated self-image seeking its own refiection in self-action in order to feel fulfilled, or of keeping up one's stock with the powerful. ${ }^{82}$

In addition to emphasizing women's constraint and complicity in their own subordination, dominance theorists also muted their acknowledgement of women's agency, often apparently for strategic purposes. Though MacKinnon, for example, sometimes sought to acknowledge the possibility of women's agency, ${ }^{83}$ she frequently did so without detailing it

82. MacKinnon, Toward a Feminist Theory, supra note 17, at 147-50. MacKinnon stops carefully short, however, of saying that any non-coercive experience of sex reflects false consciousness. In an essay aimed at responding to questioners, she noted:

In serious political analyses, say marxism [sic], a worker can sometimes have a good day or even a good job. That does not mean the worker has false consciousness or the work is not exploited labor .... Sex feeling good may mean that one is enjoying one's subordination; it would not be the first time. Or it may mean that one has glimpsed freedom, a rare and valuable and contradictory event. Under existing conditions, what else would freedom be? The point is, the possible varieties of interpersonal engagement, including the pleasure of sensation or the experience of intimacy, does not, things being as they are, make sex empowering for women.

MacKinnon, Feminism Unmodified, supra note 17, at 218.

83. MacKinnon's discussion of consciousness-raising as a feminist method, for example, acknowledges women's capacity for agency and resistance: she details the way in which recognizing the systematic-and previously unacknowledged-character of women's constraint helped women to mobilize against it. She notes:

As an experience, [consciousness-raising] went beyond empirical information that women are victims of social inequality. It built an experienced sense of how it came to be this way and that it can be changed. Women experienced the walls that have contained them as walls-and sometimes walked through them.

MacKinnon, Toward a Feminist Theory, supra note 17, at 91. MacKinnon's early work also expressed a tension between the glimmering of a distinct, resistant perspective on the part of women, and the tendency of oppression to obliterate or make impossible such a perspective,

Feminism affirms women's point of view by revealing, criticizing, and explaining its impossibility. This is not a dialectical paradox. It is a methodological 
so fully as to permit it to become the exception that swallowed her larger rule. ${ }^{84}$

Women often find ways to resist male supremacy and to expand their spheres of action. But they are never free of it. Women also embrace the standards of women's place in this regime as "our own" to varying degrees and in varying voices . . . . This, and not inert passivity, is the meaning of being a victim. ${ }^{85}$

Moreover, MacKinnon persistently deflected talk about the anti-agency implications of her emphasis on victimization. Sometimes she described these implications as the erroneous inferences of others; ${ }^{86}$ sometimes she

expression of women's situation, in which the struggle for consciousness is a struggle for world: for a sexuality, a history, a culture, a community, a form of power, an experience of the sacred. If women had consciousness or world, sex inequality would he harmless, or all women would be feminist. Yet we have something of both, or there would be no such thing as feminism. Why can women know that this-life as we have known it-is not all, not enough, not ours, not just? Now, why don't all women?

Catharine A. MacKinnon, Feminism, Marxism, Method and the State: Toward Feminist Jurisprudence, 8 Signs 635, 637 (1983).

84. MacKinnon alludes to this strategy in her Afterword to Feminism Unmodified, supra note 17 , at $218-19$. She states:

Many women in this country believe gender is a crushing reality from which no woman is exempt. They also believe, or rather act out a belief on a daily basis, that they are or can be exempt. If every tacit "present company excluded" exception I encountered on the road were excluded from the analysis, an analysis would remain that everyone accepts as generally true, but that almost no onemeaning nearly everyone-acknowledges applies to them in particular.

Id: Frances Olsen has elaborated on this strategic element in MacKinnon's argumentation in her extremely thoughtful review essay, Feminist Theory in Grand Style, 89 Colum. L. Rev. 1147 (1989) (reviewing MacKinnon, Feminism Unmodified, supra note 17).

Another feature of this general inattention to the details of women's agency in MacKinnon's work is her refusal to explain or hypothesize how some women emerge from their subordination sufficiently to become feminist organizers or leaders. See Catherine A. MacKinnon, Linda's Life and Andrea's Work, in MacKinnon, Feminism Unmodified, supra note 17, at 131 (noting that "we cannot explain the fact" that Linda Marchiano and Andrea Dworkin continue to speak and write given the pervasive subordination they have encountered). This choice, too, appears to serve MacKinnon's interest in discouraging exceptionalism. See id. at 131-32 (explaining that when such women are heard, their voices are taken as refutation of dominance theory, which ignores "the precariousness and threat of our [women's] situations").

85. MacKinnon, Toward a Feminist Theory, supra note 17, at 138. notes:

86. For example, enlarging upon her description of women as "victims," Mackinnon

The term is not moral: who is to blame or to be pitied or condemned or held responsible. It is not prescriptive: what we should do next. It is not strategic: how to construe the situation so it can be changed. It is not emotional: what one feels better thinking. It is descriptive: who does what to whom and gets away with it.

MacKinnon, Toward a Feminist Theory, supra note 17, at 138. Because her identification of women as "victims" is offered for descriptive-one might say, consciousness-raisingpurposes, Mackinnon declines to concern herself with those who may exploit its moral or emotional resonances. 
claimed that her imagery could have little effect on a vast and pre-existing system of oppression.

[T] he parade of horrors demonstrating the systematic victimization of women often produces the criticism that for me to say women are victimized reinforces the stereotype that women "are" victims, which in turn contributes to their victimization. If this stereotype is a stereotype, it has already been accomplished, and I come after. To those who think "it isn't good for women to think of themselves as victims," and thus seek to deny the reality of their victimization, how can it be good for women to deny what is happening to them? Since when is politics therapy?87

This strategy may have been intended to preserve the power of MacKinnon's critique, by preventing individual women from exempting themselves from her analysis. Yet her reluctance to confront the unintended consequences of her depictions led some feminists to believe that she viewed women's agency under oppression as insufficiently important to defend.

\section{B. The Agency Critique}

These choices of dominance feminists, amplified by the growing visibility of dominance theory, sparked a varied response from feminist critics. Unlike the sex wars critique, which reflected a confluence of theoretical and practical analyses and displayed more substantive commonality than variation, the current critique has a more fragmented configuration.

1. The Popular Critique. - The first strain of the critique has been framed by non-academic women, most, though not all, of whom consider themselves to be feminists. These women encountered dominance feminism through the anti-pornography campaigns, the cultural awakening to sexual harassment, or the re-emergent feminist activism on college campuses. While some disputed the basic premise of dominance theorythat women's oppression exists and is perpetrated by the pervasive sexualized domination of women by men-many more have questioned the specific depiction of the female subject. They have been perplexed and sometimes angered when they compared the woman depicted by dominance theorists with their perceptions of their own lives. They have asked whether they could be so completely subordinated, and whether the capacity for self-direction that they frequently experienced could be a delusion. ${ }^{88}$ Those who identified themselves as feminists have questioned how the resistance necessary to bring about change could be mobilized among women so thoroughly defined by oppression, and whether wo-

87. MacKinnon, Feminism Unmodified, supra note 17, at 220.

88. Mackinnon notes the frequency of this response to her work. See Mackinnon, Feminism Unmodified, supra note 17, at 217-19. 
men's resistance would be made more, or less, likely by women's widespread assimilation of dominance understandings. ${ }^{89}$

Some of these women have found voice in the writings of Camille Paglia, ${ }^{90}$ Katie Roiphe ${ }^{91}$, and Naomi Wolf. ${ }^{92}$ Responding to more recent expressions of dominance feminism, these writers loft many of the familiar banners of their sex wars predecessors. They allege that the dominance theorists' focus on a pervasive male sexual aggression has obscured the satisfaction and self-direction implicit in many women's sex lives. It has also enlivened a neo-Victorian regulatory urge that has produced a spate of restrictive campus rules and homogenizing education programs on date rape and sexual harassment. ${ }^{93}$ Assailing the growing influence of dominance feminists over collegiate women, these writers claim-often with marked vituperation-that this feminism has "betrayed" women by presenting them as wholly victimized and by encouraging a whiny introspection. ${ }^{94}$ Instead of acquiescing in these images of powerlessnessimages these writers reject not only as partial or damaging, but as substantially untrue-women should respond in ways that highlight and utilize their present agency. Roiphe and Paglia, who cast a skeptical eye on claims of pervasive sexual domination, propose that women respond to instances of sexual coercion with vigorous individual resistance..$^{95}$ Wolf, who is less dubious about dominance-based claims of sexualized oppression, advocates a feminism that accentuates the positive by schooling women to utilize the sources of political, economic, and interpersonal

89. This is a common reaction among some of my students each year when they are first exposed to dominance theory. They are discouraged or politically demobilized by the depth of MacKinnon's critique and her characterization of women, and they wonder how such a theory could be viewed as politically galvanizing. Another group of students, however, generally of equal or larger size, finds MacKinnon's systematic critique politically energizing because it consolidates insights that they may have had at different times but did not put together theoretically.

90. See Paglia, supra note 6.

91. See Roiphe, supra note 7.

92. See Wolf, supra note 8 .

93. Roiphe is particularly critical of these programs. See Roiphe, supra note 7 , at 8-28. For less critical discussions of campus efforts to address date rape and sexual harassment, see Kate Stone Lombardi, New Policy is Aimed at Preventing Date Rape on Campuses, N.Y. Times, Oct. 25, 1992, § 13WC, at 1; Mervyn Rothstein, More Than Dances and Picnics Greet Freshmen: Orientation at Columbia Includes Forums on Tolerance, Free Speech and Date Rape, N.Y. Times, Sept. 9, 1992, at B1; Jan Wiezorek, College Orientation Programs are Focusing on Social Issues, Chi. Trib., July 26, 1992, \& C, at 4; Judith VandeWater, Date Rape: Educators Ponder Inc[r] eased Campus Sexual Violence, St. Louis Post-Dispatch, April 27, 1992, § SC(Metro), at 1.

94. See, e.g., Christina H. Sommers, Who Stole Feminism?: How Women Have Betrayed Women (1994) (arguing that many of the most arresting claims of contemporary feminism are products of flawed; self-serving interpretation by feminist activists and acquiescent reporting by the mèdia).

95. See Paglia, supra note 6, at 53; Roiphe, supra note 7, at 101. 
power they already possess. ${ }^{96}$ All three counsel the assertion of an unabashed and self-directed sexuality. ${ }^{97}$

Although these popular writers invoke the rhetoric of the sex wars more explicitly than other proponents of the agency critique, they actually depart from the sex radicals in two salient respects. First, they domesticize, and thereby distort, the sex radical message. "Sexuality," for the popular critics, refers not to a broad investigation of pleasure and interrogation of conventional sexual boundaries, but to a mythologized or romanticized heterosexuality. "I see in the simple, swaggering masculinity of the jock and in the noisy posturing of the heavy-metal guitarist," Camille Paglia notes,

certain fundamental, unchanging truths about sex. Masculinity is aggressive, unstable, combustible. It is also the most creative cultural force in history. Women must reorient themselves toward the elemental powers of sex, which can strengthen or destroy. ${ }^{98}$

Or, in the more intimate tones of Naomi Wolf, "Male sexual attention is the sun in which I bloom. The male body is ground and shelter to me, my lifelong destination." 99 Women are asked to revere the dark, immutable allure of male sexual power, or to "come out" as satisfied heterosexuals. These conventional sexual postures are recast as radical through a juxtaposition first pioneered by Rush Limbaugh and Dinesh D'Souza ${ }^{100}$ :

96. See Wolf, supra note 8 at 306-16.

97. See Paglia, supra note 6, at 60; Roiphe, supra note 7, at $12-15$; Wolf, supra note 8 , at 187. One interesting feature in these recommendations is the way that they are often rooted in an appeal to an essential, animal nature. See Wolf, supra note 8 , at 187 ("we are beasts of the field"); Paglia, supra note 6, at 53 ("[w]oinen inust reorient themselves toward the elemental powers of sex").

98. Paglia, supra note 6, at 53. Paglia notes in the following paragraph that the only solution to the problein of date rape is "female self-awareness and self-control." Id.

99. Wolf, supra note 8 , at 186 . Wolf makes this observation in the course of a soliloquy about how her knowledge of men points to the need to pluralize the dominance thesis. "The armored monsters attacked by critics of . . . sexual violence absolutely exist. But I have had the good luck not to have slept with them." Id. I inight add that Wolf appears to have had the further good luck not to have been raped or assaulted by thein. For a pithy response to this rhapsodizing, see Anna Quindlen, "And Now, Babe Feminism," N.Y. Times, Jan. 19, 1994, at A21 ("I like guys, but my body is home to me. That was the point of feminism: I got custody of myself.").

100. Rush Limbaugh is a popular talk radio commentator who popularized the term "feminazi" to describe the threatening and coercive pressure toward homogenization imposed by feminists. Dinesh D'Souza is the author of Illiberal Education: The Politics of Race and Sex on Campus (I991), a widely-read book assailing the ostensibly ascendant and coercive force of the moveinent for "political correctness" on college campuses. Among the features these books share is the effort to present those who are privileged as under siege, and those who occupy normative, as opposed to marginal, social roles as courageously defending those roles and their attendant norms against a powerful radical onslaught. Like Roiphe, Paglia, and, to some extent, Wolf, they strive to make qualities or ways of life that are utterly mainstream appear transgressive. 
They are described as bold acts of resistance to an increasingly pervasive feminist orthodoxy. ${ }^{101}$

Second, the focus of these writers is not simply on sexuality or even sexual agency, but also on women's ability to chart a self-directed course among the varied dangers and opportunities that mark contemporary women's lives. Thus Wolf is concerned that women learn how to handle money and flex their political muscle, ${ }^{102}$ and Paglia insists that women take responsibility for their alcohol consumption. ${ }^{103}$ Women are actors capable of making choices for themselves, notwithstanding the fact that they may be subject to various gender-based pressures and dangers. This focus often has a conservative political valence in these works-stressing women's power to set their course amounts, in the works of Roiphe and Paglia, to blaming victims of sexual aggression for their own injuries, and, in the works of Roiphe, Paglia, and Wolf, to underestimating the extent of women's oppression. ${ }^{104}$ Yet it reflects a concern with women's capacity for self-direction that has been further developed in the more progressive academic branch of the critique.

2. The Academic Critique. - The academic critique of dominance feminism, which has emerged in law as well as in literary and political theory, has appeared contemporaneously with the mobilization of the

101. Of these writers, Katie Roiphe may be the most committed to asserting and describing the force of this orthodoxy. See, e.g., Roiphe, supra note 7, at 29-50 (describing Take Back The Night marches as "spectacle[s] of mass confession" with a "peculiarly aggressive" quality). For a fuller discussion of Roiphe's simultaneous effort to critique the victimizing aspects of dominance feminism and establish herself as a oncesilenced victim of its new orthodoxy, see generally Abrams, supra note 10.

102. See Wolf, supra note 8 , at 243-49, 307-16.

103. See Paglia, supra note 6 , at 64 .

104. Paglia analogizes, for example, between women walking alone at night or wearing revealing clothing and "[leaving] our purse on a park bench in Central Park: ... This is simply stupid behavior.... You may have the right to dress in that way, but you are running a risk!" Paglia, supra note 6, at 72-73; see also Roiphe, supra note 7, at 68-69 (ridiculing women for succumbing to or feeling oppressed by emotional coercion in connection with sex). Both Roiphe and Paglia tend to understate the extent of women's coercion by focusing on scenarios that do not add familiar power inequalities to sexualized behavior. For example, consider Paglia's statement: "A male student makes a vulgar remark about your breasts? Don't slink off to whimper and simper with the campus shrinking violets. Deal with it. On the spot. Say, 'Shut up, you jerk! And crawl back to the barnyard where you belong!' " Paglia, supra note 6 , at 53. This comment makes a snappy sound bite but completely neglects the ludicrousness of such a response if the comment comes, as it sometimes does, from a professor rather than a male student. Wolf does not specifically deny the extent of women's oppression or blame the victim. However, by focusing her "Power Feminism" on the circumstances of the most privileged women, she understates women's oppression by directing readers away from its more compromising manifestations. For example, the "Feminine Fear of Power," id. at 261-89, is not really the problem among women who have access to little power at all. This conservative valence explains why this contemporary critique, particularly the works of Paglia and Roiphe, has been embraced by conservatives seeking to criticize recent feminist (legal) mobilization. See infra note 154 and accompanying text. 
popular critique. ${ }^{105}$ The academic theorists encountered the dominance approach by reading feminist theory, or by observing or undertaking feminist-inspired litigation. Like their popular counterparts, they have been concerned with the depiction of agency that extends beyond the realm of the sexual. Yet, for the most part, the academic critics have been less antagonistic toward the basic message of dominance feminism. They have sought to describe a subject whose agency emerges against the backdrop of, and co-exists in tension with, systematic gender-based oppression.

105. Interestingly, the academic critique does not appear to respond directly to the popular critique. A number of legal scholars have begun to think about the implications of the popular critique and encourage its connection to the substantive concerns of academic feminists. See Higgins, supra note 10, at 3-4 (arguing that lesson to be drawn from popular critiques is that "feminism must theorize women's sexuality more systematically ... [and] concern itself with the ways in which women can and do experience pleasure under patriarchy"); McClain, supra note 10 (examining popular critiques of feminism and considering their implications for public policy); see also Abrams, supra note I0 (discussing implications of Roiphe's agency-based challenges for direction of feminist theory); Drucilla Cornell, Sexual Harassment 4 (unpublished manuscript, on file with the Columbia Law Review) (asking how, through sexual harassment doctrine, we might "both endorse sexual freedom and at the same time recoguize the legitimacy of feminist claims for equal citizenship"). These scholars have not explored the academic critique I discuss below, although I consider the above-cited works to be consistent with its basic thrust. Nor have authors such as Marcus and Mahoney articulated any connection between their work and the earlier sex-based critique.

The structure of this Article not only tracks the progress of my own thinking about this issue, but reflects my desire to highlight connections among all three bodies of work. For me, encountering the popular critique had two effects. First, its concern about the impact of dominance imagery on women's sexual self-direction-which struck me as useful, if overstated-recalled the sex wars critique and the still-unanswered questions it raised about the possibility of women's self-direction, creativity, and pleasure under oppressive conditions. Second, the superficiality and inadequacy of the answers it provided-which understated the extent of oppression (Roiphe) or overstated the extent of most women's power (Wolf) in order to encourage self-assertion, or proposed that women respond with greater pluck and resourcefulness to the immutable forces of male sexuality (Paglia) made me wonder whether there was another literature that addressed these questions more thoroughly and satisfactorily. I was also disturbed by salient, and I suspect not unintentional, threads of anti-feminist rhetoric in Paglia and Roiphe, and was curious to see if there were authors who had addressed these questions in a less antagonistic spirit. These questions led me to reconsider the work of Harris, Marcus, and Mahoney, with which I was already familiar, and to read the works of Keller and Collins, which were new to me. 
One important strain of the critique has been offered by Black feminists. ${ }^{106}$ Patricia Hill Collins's book, Black Feminist Thought, ${ }^{107}$ might be viewed as a precursor to this critique in that it expounds the perspective of Black feminists on questions of oppression and agency, without any reference to dominance theory. Collins argues that Black women struggle to live two lives-one for "them [white, dominant groups] and one for ourselves"108 - which "creates a peculiar tension to extract the definition of one's true self from the treatment afforded the denigrated categories in which all Black women are placed." 109 The unmitigated denigration of the dominant categories has led many Black women to engage in an internal process of self-definition: unlike white women, who confront a complex combination of positive and devaluative imagery, Black women cannot retain a sense of self-worth unless they develop their own images to characterize their lives. ${ }^{110}$ The process of self-definition necessitated by the extent of external devaluation is also fueled by the communities within which Black women live. The bonds among family, among members of churches and other organizations, and among Black women themselves lend support to this effort, as well as supply concrete, positive terms in which Black women's lives can be seen. ${ }^{111}$ Artistic sources of

106. Following the practice of many, though not all, critical race theorists, I shall use an upper-case " $B$ " when I use the word "Black." My justification is aptly stated by Kimberlé Crenshaw, who notes, "Blacks, like Asians, Latinos and other 'minorities,' constitute a specific cultural group and, as such, require denotation as a proper noun." Crenshaw, supra note 81 , at 1332 n.2. Although there are some who believe that whites constitute a specific cultural group, 1 do not share this view and hence will use a lower-case " $w$ " when I use the term "white."

107. Patricia Hill Collins, Black Feminist Thought: Knowledge, Consciousness, and the Politics of Empowerment (1991). Collins notes in her introduction:

I place Black women's experiences and ideas at the center of analysis. . . .

[M] iddle-class, feminist readers will find few references to so-called white feminist thought. . . . While I am quite familiar with a range of historical and contemporary white feminist theorists and certainly value their contributions to our understanding of gender, this is not a book about what Black women think of white feminist ideas or how Black women's ideas compare with those of prominent white feminist theorists.

1d. at xii-xiii.

108. Id. at 94 (quoting John Langston Gwaltney, Drylongso: A Self-Portrait of Black America 240 (1980)).

109. Id.

110. See id. at 95.

111. See id. at 95-99. Collins warns, however, that:

The resulting reality is much more complex than one of an external white society objectifying Black women as the Other with a unified Black community staunchly challenging these external assaults through its "culture of resistance." Instead, African-American women find themselves in a web of cross-cutting relationships, each presenting varying combinations of controlling images and Black women's self-definitions.

Id. at 95-96. Collins's emphasis on Black women's self-definitions, and the way they are fueled by different bonds within Black communities, is presumably intended to emphasize a resource on which Black women draw that is not sufficiently acknowledged by the 
positive self-definition for Black women also contribute: in the lyrics of the Blues, and in Black women's literature, Black women find images of sexual self-respect and self-direction, familial and personal responsibility, economic self-sufficiency, and aspiration. ${ }^{112}$

The separate self-definition that Black women create from these and other sources may function as a source of internal self-respect. Even a woman whose external constraints compel her to "remain 'motionless on the outside' . . . can always develop the 'inside' of a changed consciousness as a sphere of freedom." 113 This 'inside' enhances her ability to withstand oppressive treatment without having her identity poisoned by its devaluative content. It also offers a critical vantage point on dominant understandings, which can be a spur to political critique and resistance. Black women empowered by the 'inside' of independent self-definition, Collins argues, can challenge the accuracy of the dominant images, the power relations that make their propagation possible, and the specific instances of oppressive treatment that are enabled by both. ${ }^{114}$

Similar themes emerge in the work of Black feminists who have sought more directly to critique dominance feminism. These theorists argue that the victimized depictions of dominance feminism fail to square with the agency manifested by women of many racial groups. Some, like Collins, point to the way that women of color have forged their own self-conceptions and have mobilized within their own communities to oppose oppression on the basis of race and sex. ${ }^{115}$ Others have noted that a portrait of woman as victim obscures the very real agency white women exercise in constructing race in society ${ }^{116}$ and perpetuating race-based thinking within the feminist movement. ${ }^{117}$

dominant society, and perhaps (although I am less clear about this) not fully recognized by all Black women themselves.

112. See id. at 99-103, 107-10.

113. Id. at 111. As an example of this kind of internal self-respect, Collins cites the perspective of an elderly domestic worker named Sara Brooks, who states, "I may not have as much as you, I may not have the education you got, but still, if I conduct myself as a decent person, I'm just as good as anybody." Id. at 108 (citing You May Plow Here: The Narrative of Sara Brooks 132 (Thordis Simonsen ed., 1986)).

114. See id. at 110-13.

115. For other examples of scholarship highlighting such activity, see Kimberlé Crenshaw, Mapping the Margins: Intersectionality, Identity Politics and Violence Against Women of Color, 43 Stan. L. Rev. 1241, 1251-82 (1991) (describing marginalization of and political response by women of color within areas of rape and spousal abuse); Hall, supra note 29, at 337-40 (describing work by Black and white women activists to sever connections between rape allegations and lynchings).

116. This point has been made with considerable eloquence by Martha Mahoney, a white feminist. See Martha Mahoney, Whiteness and Women in Practice and Theory: A Reply to Catharine MacKinnon, 5 Yale J. of L. \& Feminism 217, 239-44 (1993).

117. See, e.g., Angela P. Harris, Race and Essentialism in Feminist Legal Theory, 42 Stan. L. Rev. 581, 614 (1990). 
Angela Harris' article, "Race and Essentialism in Feminist Legal Theory," exemplifies this strain of the agency critique. ${ }^{118}$ Dominance theory shares a central flaw of the "essentialist" feminisms Harris critiques: ${ }^{119}$ a tendency to find women's essence, or at least their commonality, in their shared victimization. After explaining how MacKinnon's theory universalizes the experiences of white women, erasing or marginalizing the experience of women of color, ${ }^{120}$ Harris critiques the underlying premise of a unifying victimization. "[T] he story of woman as passive victim," she states, "denies the ability of women to shape their own lives, whether for better or worse. It also may thwart their abilities. ... [W]omen who rely on their victimization to define themselves may be reluctant to let it go and create their own self-definitions." 121

The process of creating one's own self-definitions is, for Harris, complex. It involves mediating among the "voices" that speak within each person-voices shaped by multiple, sometimes conflicting, group-based identities, and the varying circumstances that have given them meaning. Women define themselves by forging a temporary, contingent unity among these multiple voices. ${ }^{122}$ Illustrating this process of creative selfconstruction, Harris invokes a metaphor of Zora Neale Hurston. Hurston describes herself as:

a brown bag of miscellany propped against a wall, in company with other bags, white, red and yellow. Pour out the contents, and there is discovered a jumble of small things priceless and worthless. ... In your hand is the brown bag. On the ground before you is the jumble it held . . . ${ }^{123}$

The color of the "bag," and the dominant meanings assigned to it, may be given. These are the social constraints under which any woman operates. But the act of filling it-deciding what, among the objects initially deposited within, will give shape and weight and texture to any particular bag-is the woman's choice. It is this potential for creating and re-creating ourselves, even under the circumstances of our constraint, that is shared among women, though it is a commonality that gives rise to inevitable differences.

With these images of filling bags, of creating temporary unity among discordant voices, Harris decenters Collins's image of "inside" and

118. See id.

119. Harris describes gender essentialism as "the notion that a unitary, 'essential' women's experience can be isolated and described independently of race, class, sexual orientation, and other realities of experience." Id. at 585. She critiques two theories that she presents as paradigmatic forms of feminist essentialism: those of Catharine MacKinnon, see id. at 590-601, and Robin West, see id. at 602-04.

120. See id. at $590-601$.

121. Id. at 613.

122. See id. at 612-15.

123. Zora Neale Hurston, "How It Feels to be Colored Me," in I Love Myself When I am Laughing ... and Then Again When I am Looking Mean and Impressive: A Zora Neale Hurston Reader 152, 155 (Alice Walker ed., 1979). 
"outside" voices, highlighting instead a complexity of influences and a contingency in the resulting self-definition to which Collins only alludes. ${ }^{124}$ Yet her notion of self-definition as a process involving women's creativity and assertion of will is importantly similar to Collins's own. Accepting a view of women as victims of sexualized domination erases and impedes this crucial activity by obscuring those ways in which women can be oppressors as well as oppressed, and by obscuring the creativity and choice through which women work toward their own self-definitions. The agency possessed by women, for Harris, may be a force for good or for evil; but it is a force obscured and undermined by dominance-based depictions.

A second strand of the academic critique endorses the notion of Collins and Harris that women's agency inheres in their power of interpretation. Yet these theorists propose that women apply that power not only to their self-images, but to the oppressive circumstances under which they live. Interpretation, in the eyes of these feminists, is an instrument for highlighting the ambiguous, multiply-constructed character of social life. Their quarrel with dominance theory arises from what they see as its objectivist and structuralist tendencies. These tendencies suggest that there is one way to interpret sexual practices or imagery-as incidents of a totalizing gender oppression-and that other interpretations run the risk of self-delusion. These theorists advocate the use of interpretation to expose the ambiguity of ostensibly coercive practices-an ambiguity that makes them susceptible to resistance. Particularly when its risks are minimized by the protection of legal rules, interpretation is a potent force that can help women redefine and redirect themselves.

Susan Keller's article, "Viewing and Doing: Complicating Pornography's Meaning,"125 exemplifies this approach. Keller challenges both MacKinnon and Dworkin's argument for the anti-pornography ordinance and "middle ground" efforts ${ }^{126}$ to regulate a narrower category of pornography. She argues that both go wrong by assuming a unitary relation between "viewing" and "doing" (that is, what is viewed will be done by men to women) and by inferring a unitary message from pornographic representations. Potential regulators, Keller argues, should view the influence of pornography on women's sexuality as a process encompassing several different phases-the production of pornography, the

124. Harris describes the process of forging unity or identity within a multiplicitous self as particularly well exemplified in the writings of Black women. See Harris, supra note 117 , at 608 , and particularly necessary to Black women, "given a society that denied them full selves," id. at 613 , but "not unique to black women," id. at 608 .

125. Susan E. Keller, Viewing and Doing: Complicating Pornography's Meaning, 81 Geo. L.J. 2195 (1993).

126. Keller highlights in particular the work of Cass Sunstein, who has sought to identify a narrower body of pornographic materials-in general, visual materials most strongly linked by social science research with violence against women-that might be regulated consistently with the constraints of First Amendment doctrine. See id. at 2198, 2205-07. 
viewing of pornography, the use of pornographic images in viewers' erotic lives-which function according to different logics. The latter two phases ("viewing" and "doing") are subject to far more variable interpretation and application than the dominance-based hypothesis suggests. This variability exists because of multiplicity in interpretation or identification. An incident of non-consensual sex depicted in pornography may or may not be interpreted by the viewer as coercive to its victim; female viewers may identify with the female target of sexual aggression, with the male aggressor, or move between identifications with the aggressor and his target. ${ }^{127}$ Variability also exists because of gaps between viewers' interpretation of a pornographic representation and their application of the representation in their own erotic lives. A viewer might enjoy observing coercive sex performed by others, or she might fantasize about coercion during her own sexual encounters, without actually wanting to be coerced herself. ${ }^{128}$

This variability means that the creation or reinterpretation of pornography may be a salient route to self-exploration as well as a viable form of resistance. ${ }^{129}$ Pornography does not simply permit women to project new images of women's subjectivity-pluralizing, in the manner of the sex radicals, a marketplace of sexual ideas. Its amenability to multiple interpretations, instead, permits its interpreters to expose and

127. See id. at 2231.

128. See id. at 2222. In a particularly interesting discussion of these sources of variability, Keller identifies four different levels of practice that might be comprehended by the term sadomasochism: "lived" sadomasochism (the conventional understanding of sadomasochism as abuse stemming from pathologically pleasurable relations of control and dependence-which may or may not describe any actual relationships); "ritual" sadomasochism (an erotic practice of including the infliction of pain characterized by the presence of stylization and mutually understood boundaries); "pretend" sadomasochism (mimicking certain elements of ritual or lived sadomasochism without actually inflicting pain); and "fantasy" sadomasochism (practice of fantasizing about any other levels of sadomasochism, without actually acting on them, even to the extent of mimicry). She explains that the erotic appeal of sadomasocbistic imagery in pornography could be experienced at any one of these levels (some of which include no "acting out" of sadomasochism), and that couples, for example, who enjoy practicing sadomasochism at one level themselves could get erotic satisfaction out of observing its practice at an entirely different level. See id. at 2218-22. For another example of a feminist theorist, in this case quite sympathetic with dominance theory, who argues that women might enjoyably employ scenarios of sadomasochism in the context of relationships characterized by "trust and care," see Lynne Henderson, Getting to Know: Honoring Women in Law and in Fact, 2 Tex. J. Women \& L. 41, 62-63 (1993).

129. See Keller, supra note 125, at 2229 (for those who see the "message and effect" of pornography as "dynamic," working with it "presents the exciting possibilities of deconstructing and reconstructing female and male sexuality, while challenging patriarchy"). Following Judith Butler, Keller argues that MacKinnon's goal of radically transforming the social context by eliminating pornography is as utopian as an effort to exit the social context or to function acontextually. See id. ("if sexuality is culturally constructed within existing power relations, then the postulation of a normative sexuality that is "before," "outside," or "beyond" power is a cultural impossibility and a politically impracticable dream") (quoting Butler, supra note 41, at 30). 
problematize sexual arrangements often accepted as unproblematic norms. Gay or lesbian pornography that depicts dominance relations associated with heterosexuality in non-heterosexual contexts may " $[\mathrm{b}]$ ring into relief the utterly 'constructed status of the so-called heterosexual original." "130 Madonna's use of her body as a "metafeminine prop" or her appropriation of the Marilyn Monroe look ${ }^{131}$ may expose widely accepted images of female desirability as male-created constructs, which can be challenged through rearrangement, exaggeration, or parody by women. ${ }^{132}$

Keller acknowledges that the reinterpretation of pornography does not guarantee socially transformative results: the same elements-the use or invocation of dominant norms-that permit it to function as a vehicle for political challenge may also be interpreted as reproducing or supporting oppressive gender relations. ${ }^{133}$ Yet using law to change the social context in which pornography is produced may enhance the plausibility of empowering interpretations, while mitigating the possibility that oppressive messages will predominate. Though Keller rejects the trafficking, forcing, and attack provisions ${ }^{134}$ of the MacKinnon-Dworkin AntiPornography Ordinance, she endorses those that prevent coercion of models and actresses in the production of pornography. ${ }^{135}$ The "models and actors" regulation assures viewers that real women are not being coerced in the production of pornography, permitting them to pluralize the relation between real and fantasized coercion in their own lives, and to engage in more empowering interpretations of pornographic images. ${ }^{136}$

130. Keller, supra note 125 , at 2238 (quoting Butler, supra note 41 , at 31 ).

131. These examples come from Katherine Franke, Cunning Stunts: From Hegemony to Desire: A Review of Madonna's Sex, 20 N.Y.U. Rev. L. \& Soc. Change 549, 566 (1994), but they partake of Keller's deconstructive analysis of pornography.

132. See Susan E. Keller, Review Essay, 18 W. St. U. L. Rev. 463, 463-65 (1990) (reviewing Madonna, Justify My Love (Warner Reprise Video 1990) and Andrew Ross, No Respect: Intellectuals and Popular Culture (1989)).

133. See Keller, supra note 125 , at $2239-42$.

134. The trafficking, forcing, and attack provisions are paragraphs 5,2 , and 3 , respectively, of $\S 3$ of the MacKinnon-Dworkin Anti-Pornography Ordinance, supra note 5.

135. See Keller, supra note 125, at 2237-38, 2239-42. The models and actors provision, Section 1 of the MacKinnon-Dworkin Anti-Pornography Ordinance, supra note 5 , is discussed supra note 56 . Keller does express concern about the broad definition of coercion in the Anti-Pornography Ordinance, noting "the conflict between a recognition that coercion extends beyond liberal notions of choice and a desire to grant women a sense of empowerment and agency to make choices." Id. at 2201. See also id. at 2242 (suggesting that a more complex interpretation of pornography might facilitate recognition of some women's uncoerced decision to participate in its production).

136. One might wonder why, if Keller's goal is to render the relation between "viewing" and "doing" fluid and plural, rather than unitary, she does not also favor the provision of the Ordinance permitting a claim when a woman is "assault[ed], physically attack[ed], or injure[d] . . . in a way that is directly caused by specific pornography." MacKinnon-Dworkin Anti-Pornography Ordinance $\$ 3(3)$, supra note 5, at 140; see also supra note 56. This provision would seem to prevent the imposition of a unitary 
The reinterpretation of pornography, for Keller, helps women to achieve a kind of agency similar to that described by Collins. ${ }^{137} \mathrm{~A}$ woman who has enjoyed the messages that may be found in transgressive depictions, or more conventional depictions interpreted in transgressive ways, comes to assign meanings to women's sexuality that differ from those assigned by dominant society. The revised view of her sexuality that she gains through this activity may provide the woman with an "inside" not poisoned by dominant images, even if she never makes this reinterpretation public. To the extent that she produces her own transgressive pornography, or engages in public reinterpretations of pornography produced by others, she may use this new imagery (and her emerging selfdefinition) to expose and critique dominant understandings.

Sharon Marcus's article, "Fighting Bodies, Fighting Words: A Theory and Politics of Rape Prevention," 138 provides a second example of this approach. Rather than seeing women's agency in their achievement of sexual pleasure and social critique, she sees it in their potential for resisting coercion, in this case the coercion of rape. Marcus argnes against the position-common to dominance feminists and others who resist the "textuality"139 of women's lives ${ }^{140}$ - that rape is an incontestable fact of women's lives, the predictable outcome of a vulnerability sufficiently

relationship between "viewing" and "doing" (between fictionalized coercion and real coercion) in the later stages of the pornographic process.

137. The analogy here is my own. It is not clear that Collins would subscribe to the view that the reinterpretation of pornography permits women to achieve the sorts of agency she describes. In fact, her position that the objectifying depiction of women in pornography parallels the treatment of Black women in dominant society, see Collins, supra note 107 , at $167-73$, suggests that she comes closer to a dominance position on this issue than on the question of women's agency more generally.

138. Sharon Marcus, Fighting Bodies, Fighting Words: A Theory and Politics of Rape Prevention, in Feminists Theorize the Political 385 Judith Butler \& Joan W. Scott eds., 1992).

139. I use the term here, as Marcus does, to denote amenability to variable interpretation.

140. Marcus's exphcit antagonists on this point are Susan Brownmiller and Mary Hawkesworth. Brownmiller, who was viewed by sex radicals as a dominance feminist, has a biological emphasis not present in all dominance-based accounts; she ascribes the inevitability of rape to the vulnerability created by female biology. See Brownmiller, supra note 16 , at 4 (" $[I] n$ terms of human anatomy the possibility of forcible intercourse incontrovertibly exists. This single factor may have been sufficient to have caused the creation of a male ideology of rape. When men discovered that they could rape, they proceeded to do it."). Hawkesworth, like MacKinnon, identifies rape as one of "the realities that circumscribe women's lives" and she privileges, in an epistemological sense, the victim's account of this experience. Mary E. Hawkesworth, Knowers, Knowing, Known: Feminist Theory and Claims of Truth, 14 Signs 533, 555 (1989). Hawkesworth places greater emphasis, however, on defending victim-centered accounts of sexual violation against what she views as relativistic postmodern constructions. She notes:

The undesirable consequences of the slide into relativism that results from too facile a conflation of world and text is particularly evident when feminist concerns are taken as the starting point. Rape, domestic violence, and sexual harassment ... are not fictions or figurations that admit of the free play of signification. The 
characteristic to define the gender. She contends, instead, that rape should be understood as a "language": the enactment by two parties of a cultural script that both reflects and further socializes those parties to roles of male dominance and female submission. ${ }^{141}$ Marcus notes that

[p]atriarchy does not exist as a monolithic entity separate from human actors and actresses, impervious to any attempts to change it ... rather [it] acquires its consistency as an overarching descriptive concept through the aggregation of microstrategies of oppression such as rape. Masculine power and feminine powerlessness neither simply precede nor cause rape; rather, rape is one of culture's many modes of feminizing women. ${ }^{142}$

Moreover, as the term "script" suggests, rape must also be viewed as a "process" with a temporal dimension. Marcus criticizes law reform efforts, whose focus on punishing rape collapses the distinction between the attempt and the completed act, ${ }^{143}$ and advocates viewing rape as a "process of gendering" in which "one person ... strives to maneuver the other person into the role of the victim,"144 creating a space in which resistance becomes possible. Responses to a rape attempt that reject the assigned female posture of paralysis, fear, and submission may disrupt the enactment of the script in the individual instance and weaken its power as a social construct.

victim's account of these experiences is not simply an arbitrary imposition of a Id. purely fictive meaning on an otherwise meaningless reality.

141. Marcus notes:

The language of rape solicits women to position ourselves as endangered, violable, and fearful and invites men to position themselves as legitimately violent and entitled to women's sexual services. This language structures physical actions and responses as well as words, and forms, for example, the would-be rapist's feelings of powerfulness and our commonplace sense of paralysis when threatened with rape.

Marcus, supra note 138 , at 390 . Marcus also discusses several other senses in which rape might be viewed as a "linguistic fact," each of which play a role in her ultimate argument. See id. at 388-89. First, she finds a conjunction of rape and language in the way that our culture "churns out [images of rape], representations which often transmit the ideological assumptions and contradictions of rape-women are rapable, women deserve rape/ women provoke rape ...." Id. at 389 . Second, she highlights the presence of speech in rape attempts, and the fact that women's failure to resist often arises "as much from the self-defeating rules which govern polite, empathetic feminine conversation as [it does] from explicit physical fear." Id. Third, Marcus places rape and language within a " 'continuum' theory of sexual violence." "[O]bscene remarks, threats and other forms of harassment" are not themselves rape, but "gesture toward a rape," id.; they are part of the more extended process of a rape attempt. Understanding them as such-resisting the temptation to collapse the "temporal and logical distinction" between them and the actual rape-creates a space in which women "can try to intervene, overpower and deflect the threatened action." Id.

142. Id. at 391.

143. Cf. id. at 387-88 (arguing that legal reforms seem to assume inevitability of rape and that "only postrape events offer possible occasions for intervention," thus obscuring possibility of a "politics of rape prevention").

144. Id. at 391. 
Like Collins and Keller, Marcus suggests that women achieve agency through the reinterpretation of dominant images. But she proposes that women undertake reinterpretation with less support or explanation, and under more perilous conditions than do Collins or Keller. Unlike Collins, who sees Black women moving toward self-definition with the support of a community, Marcus's reinterpretation is an individual effort. Even rape counselors and feminist law reformers are described as allies of the dominant view. Unlike Keller, who details a reinterpretive effort already undertaken by filmmakers, performance artists, and others-an effort that can be practiced in the privacy of one's own room-Marcus proposes that women act on a comparatively novel interpretive theory in the heat of a rape attempt. ${ }^{145}$ Yet, such comparisons notwithstanding, Marcus is not immune to the dangers of her proposal. She considers, first, the concern that women who might have minimized their physical injury by submitting to a rapist may be more seriously injured through their attempts to weaken the force of a "social construct," and second, the possibility that the law might seek to "encourage" her resistance strategies by making a showing of such resistance the sine qua non of a successful rape prosecution.

The widespread sense that female opposition is risky or impossible is, to Marcus, a product of the "rape script" itself. ${ }^{146}$ This cultural construction is exacerbated by self-defense advice stressing acquiescence that Marcus describes as empirically ungrounded.147 Giting Pauline Bart and Patricia O'Brien's Stopping Rape: Successful Survival Strategies, ${ }^{148}$ Marcus argues that women's resistance does not correlate with the use of additional force by assailants and that passive responses often lead to increased violence by the attacker. ${ }^{149}$ Moreover, strategies from flight to verbal chiding or aggression to physical resistance "can suffice to block a man from continuing a rape attempt." 150

Marcus also rejects a legal requirement of disruptive resistance as a coherent application of her theory. Such requirements have more often been used to exonerate accused rapists than to encourage agentic behav-

145. I would argue that in its prospective, normative focus, Marcus's work differs from that of authors like Bart and O'Brien, who describe, retrospectively, the unconventional strategies that have worked in thwarting rape attempts. See Pauline B. Bart \& Patricia H. O'Brien, Stopping Rape: Successful Survival Strategies (1985). Marcus's normative, prospective focus encourages the individual to engage in these disruptive strategies should she become the target of a rape attempt, and, in the strength of its criticism of more acquiescent responses, suggests that she may be subject to moral or political (though apparently not legal) criticism if she does not.

146. Women socialized to fear rape become "subjects of fear" - subjects for whom fear triggers not the "fight or flight" response, but the self-obliterating "sensations of 'freezing' -involuntary immobility and silence." Marcus, supra note 138, at 394.

147. See id. at 395-96.

148. Bart \& O'Brien, supra note 145. $40-41)$.

149. See Marcus, supra note 138 , at 395-96 (citing Bart \& O'Brien, supra note 145 , at

150. Id. at 396 (citing Bart \& O'Brien, supra note 145, at 40-41). 
ior on the part of women; moreover, they assign to women the costs of noncompliance with an attitudinal norm that can only emerge over time. ${ }^{151}$ Legal authorities should instill a new understanding of rape not by requiring disruptive resistance to demonstrate non-consent, but by revising those legal doctrines whose characterizations of women contribute to or reinforce the rape script. 152 Thus, for Marcus, as for Keller, law provides the background condition that enables or protects the central activity through which women express agency: resistant reinterpretation by individual women.

A final group of academic critics endorse the central insight of dominance feminism but fear that its muted approach to agency might be manipulated or misunderstood. ${ }^{153}$ This concern has been underscored by two recent developments: the first is a conservative critique of the feminist resort to law. ${ }^{154}$ This critique, mounted by social and political conservatives but fueled by the pointed accounts of writers such as Paglia

151. Marcus states:

This is not to say that women must demonstrate resistance to provide legal proof that sexual overtures were undesired. A resistance criterion for defining rape has often been used to absolve rapists by expecting women trained in passivity to be able to display the same levels of aggressivity as men .... . We should not be required to resist to prove our innocence at some later judicial date, but we should do so to serve our own immediate interests.

Id. at 392 .

152. Here Marcus has a range of suggestions, though many are less than fully elaborated. The classification of rape as a sexual offense, rather than an assault, prevents it from being considered as an instance of "subject-subject violence" in which two full subjects face each other as antagonists. Instead, defining rape as a sexual offense "separates sexual parts from the person and views them as objects which have been violated." The woman as a full subject, as opposed to a "wounded inner space," seems to disappear from the legal characterization. See id. at 397, 400. Contract, property, and family law may also contribute to the rape script, inasmuch as they describe women as the property of men or as less than fully capable of alienating or exchanging property. See id. at 397-98. Finally, the use of past sexual history in rape trials may also contribute to characterizing female sexuality as a "violated inner space" rather than one attribute of a full human subject, because it denies female sexuality the ability to change over time. See id. at $399-400$.

153. I would characterize my own position as falling most squarely in this final camp. Several years ago, I expressed the concern that MacKinnon's strategic underemphasis of women's choice or agency would undermine her effectiveness with certain audiences. See Kathryn Abrams, Ideology and Women's Choices, 24 Ga. L. Rev. 761, 761-62 (1990). However, I have more recently become concerned that this emphasis permits her work, like the work of Lenore Walker and other dominance theorists, to be misunderstood, mischaracterized and manipulated by conservative commentators and courts. See Abrams, supra note 10, at 1552-57. I also believe that the strategic repression or muting of the agency theme results in an imbalanced portrait of women's lives that discourages them from noticing or availing themselves of a resource that is crucial to their resistance.

154. For a fuller description of this backlash effort, see Susan Faludi, Backlash: The Undeclared War Against American Women 237-39, 400-53 (1991). For examples of this literature in the area of date rape, see Neil Gilbert, Realities and Mythologies of Rape, Society, May-June 1992, at 4, 9-10; The Making of a Crisis, Playboy, Nov. 1990, at 54; John Leo, What Qualifies as Sexual Harassment?, U.S. News \& World Rep., Aug. 13, 1990. 
and Roiphe, questions the growing number of women seeking legal remedies in response to sexual harassment or acquaintance rape. In a familiar yet highly effective move, it seeks to turn the spotlight from the wrongs of the offenders to the attributes of their victims. The critique describes victims of the most severe violations as wholly compromised beings; it labels others as overly sensitive souls who find offense in the most innocuous of circumstances or lack the savvy to steer themselves clear of trouble. The critique claims that those who seek legal recourse have expanded the scope of an already-intrusive state through their inability to fight their own fights. More pointedly, conservative critics charge dominance feminists with responsibility for creating a generation of women so quick to see injury and so unable to rectify their situations without resort to law.

Many feminists view this critique as a cynical effort by anti-feminists to make the role of the victim or the legal complainant unpalatable. ${ }^{155}$ But the conservatives' warning-that dominance theory might shape the victim as well as expose the perpetrator-has been echoed by a less conclusively hostile source. Recent judicial decisions in several areas have recognized gender-specific injuries, yet characterized the victims of such injuries as atypically passive or otherwise impaired. For example, courts applying the theory of "learned helplessness"156 have increasingly questioned the capacity of battered women to protect the interests of their children, a move that has sometimes led to denials of custody. The requirement that sexual harassment plaintiffs demonstrate "serious psychological injury," fortunately short-lived, raised the specter that successful sexual harassment claimants would be regarded as women who had been incapacitated in their personal and professional lives. ${ }^{157}$

These influences have led some feminists to fear that the critical contributions of dominance feminism will be overwhelmed by the negative political and personal consequences of failing to recognize agency among oppressed women. Their response is to highlight, in the course of describing women's oppression, those incidents of self-direction that emerge in the lives of systematically oppressed women. This approach seeks to acknowledge the limited but salient instances of resistance and responsibility that occur in that context, and to prevent the emergence of legal doctrines that add stigmatizing representations to the oppressions that women already endure. ${ }^{158}$

155. See Abrams, supra note 10, at 1540-48 (levelling this criticism against Roiphe and conservative commentators she cites on subject of date rape); Katha Pollitt, Not Just Bad Sex, The New Yorker, Oct. 4, 1993, at 220 (same).

156. See Martha R. Mahoney, Legal Images of Battered Women: Redefining the Issue of Separation, 90 Mich. L. Rev. 1, 38-43 (1991).

157. See Kathryn Abrams, Sexual Harassment at a Crossroads: Law and Culture in the Regulation of Sexual Injury (unpublished manuscript, on file with the Columbia Law Review).

158. On the question of women being disadvantaged by gender oppression and stigmatizing representations, see Linda McClain, supra note 10 , at 107 \& n.24. 
This final approach is exemplified by Martha Mahoney's "Legal Images of Battered Women."159 Mahoney views dominance feminism as an influential theory that has already infused cultural understandings and important corners of the law. Unlike Keller and Marcus, who see this development as largely problematic, Mahoney sees in it both benefits and drawbacks. The dominance-informed theory of "learned helplessness" has educated the public about battering and facilitated the defense of battered women who kill their spouses. ${ }^{160}$ Yet because the theory, and its application in the litigation context, have been insufficiently attentive to the expressions of women's agency under oppression, these contributions have come at a cost: battered women's self-defense work utilizing the theory of "learned helplessness" has fed on and reinforced a view of battered women as pathologically passive. ${ }^{161}$ This view has led to denial and confusion among battered women who do not recognize themselves in the unitary images of victimization and to legal detriment when they seek custody of their children. ${ }^{162}$

Mahoney proposes that the unitary images of dominance theory be supplemented by accounts that incorporate the daily acts of self-preservation, familial protection, and outright resistance that she sees in the narratives of battered women. ${ }^{163}$ These narratives suggest, for example, that a battered woman is not simply in thrall to her spouse. She sees someone who was once a loving partner or perhaps an attentive parent; she also sees a menace whose violence threatens her well-being and her life. ${ }^{164}$ And she is not simply passive in the face of physical onslaughts. She may endeavor to control the location or timing of the violence, to secure her children from its force, to escape it entirely if she is not impeded by financial dependency or by her partner's violent pursuit. ${ }^{165}$ This complex, sometimes contradictory imagery suggests a female subject similar to that described by Angela Harris. Like Harris, Mahoney believes that law can play a critical role in fostering the recognition and serving the needs of such a subject. Two legal initiatives, in particular, can suggest a more complex reality behind the often-stigmatizing label "battered woman."

First, legal advocacy on behalf of battered women can incorporate the emerging feminist construction of a battering relationship as a two-

159. Mahoney, supra note 156.

160. See id. at $36-37,42$.

161. See id. at $34-43$.

162. See id. at 11-13 (denial); id. at 43-49 (loss of custody).

163. Mahoney notes that:

women's stories as well as much social science literature indicate that many battered women seek energetically to protect themselves and their families. In this vein, the most socially situated description of learned helplessness describes it as a product of the interaction of frustrations women meet as they energetically pursue safety.

Id. at 41.

164. See id. at $21,49-53$.

165. See id. at 22-23, 61-63, 66-68. 
way struggle for power and control. ${ }^{166}$ This understanding shares the power focus of dominance feminism but depicts the woman as a strong responsive force whose actions trigger reactions from her batterer. Second, the law can recognize the distinct offense of "separation assault"an intensified phase of abuse that follows, and sometimes terminates, the attempt of a woman to leave her batterer. ${ }^{167}$ Describing, and imposing sanctions on, separation abuse would highlight contexts in which resistance (via exit) had been part of a woman's response to domestic violence; it would also broaden cultural understandings of the brutal force with which women often must contend in order to effectuate that resistance.

\section{Distinguishing the Critiques}

1. The Emergence of Partial Agency. - The first distinguishing feature of the emerging critique has been an account that foregrounds questions of agency, more concretely juxtaposing women's capacity for self-direction and resistance, on the one hand, with often-internalized patriarchal constraint, on the other. The explorations of sexual pleasure undertaken by the sex radicals did not seek to dichotomize pleasure (agency) and danger (constraint). ${ }^{168}$ Yet in much of the writing of this period, the constraints imposed on sexuality or sexual agency by gender oppression (or even feminism) were treated as background conditions while the explicit emphasis was on women's capacity for sexual invention and exploration. ${ }^{169}$ The emerging practice of juxtaposing agency and constraint, which 1 will refer to as highlighting partial agency, has different manifestations in different branches of the critique. Yet this range may be suggested by surveying three sub-categories: transcendent agency, psychological or internal agency, and political agency.

Transcendent agency is best captured in the work of popular agency critics, such as Roiphe and Paglia, and Sharon Marcus. According to these theories, dominance feminism either exacerbates (Marcus) ${ }^{170}$ or overstates (Roiphe and Paglia) ${ }^{171}$ the insults of a sexist society by under-

166. See id. at 53-60.

167. See id. at $61-93$.

168. The works of Gayle Rubin, see, e.g., Gayle Rubin, Thinking Sex: Notes for a Radical Theory of the Politics of Sexuality, in Pleasure and Danger, supra note 3, at 267, or Dorothy Allison, see, e.g., supra note 30, described struggles for sexual expression, satisfaction, or security in the context of norms wrought by sexism or sexual hierarchy that made women desperately ashamed of their sexual desires. In other works, such as Joan Nestle's exploration of "The Fem Question," constraining norms born of sexism, heterosexism, and feminism, became the occasion for re-examining a certain form of sexual intimacy. See Nestle, Thè Fem Question, supra note 29.

169. The works of Ellen Willis, supra note 34, or Amber Hollibaugh, supra note 26, are good examples.

170. See Marcus, supra note 138, at 385-88 (describing views of dominance theorists and sympathetic law reformers regarding inevitability of rape as helping to make that inevitability a self-fulfilling prophesy).

171. See Roiphe, supra note 7, at 12-15, 27-28 (describing dominance influenced safety and education programs on college campuses as creating rather than responding to 
scoring the powerlessness that practices such as rape or sexual harassment produce. The proposed response for women is to step beyond the collaborative script with an uncompromised act of self-assertion that serves to mitigate the script's effects. The specific proposals range from the serious (for example, Marcus's suggestion that women undertake disruptive resistance to rape attempts) ${ }^{172}$, to the trivial (for example, Roiphe's narrative of a woman dumping milk on a potential sexual harasser) ${ }^{173}$.

The transcendence of dominance-imposed constraint, for the individual woman involved, seems readily achieved-a position that is puzzling in light of the power these writers ascribe to dominance-based views or scripts. For Roiphe and Paglia, simple exposure to a contrary view seems sufficient to free women from the shackles of victimization. ${ }^{174}$ For Marcus, the process is slightly more complicated, yet recognizing the social constructedness of women's vulnerability - a process aided by theory and by the promulgation of competing images through law-may be enough to fuel resistant, script-disrupting responses. ${ }^{175}$ None of these writers focuses on the weight of internal barriers to resistance, or the possibility that resistant acts will not succeed. This relatively uncomplicated transcendence suggests that, surrounded as women are by dominancebased scripts, they have not internalized them in ways that make departure difficult. This suggestion, that a subject is formed prior to, rather than in consequence of, social influence, seems more consistent with Roiphe's unsophisticated libertarianism than with Marcus's social constructivism. This view may be placed within the category of "partial agency" only because this kind of transcendence must be repeatedly reenacted. Because individual resistance affects broader patterns of oppression only slowly at best, a woman who resists on one occasion may be subject to coercion at a later date.

Psychological or internal agency describes the efforts of women to define themselves in terms not entirely tainted by dominant understandings. While it is featured most prominently in the works of Collins and Harris, who describe the shared struggles of Black women to develop independent self-conceptions, ${ }^{176}$ it also plays a role in the work of white feminists such as Keller and Mahoney. The woman who uses pornography to develop new affirmative conceptions of her sexuality exercises internal agency, as does the battered woman who strives to retain her sense

an atmosphere of fear); Paglia, supra note 6, at 49-50 (citing feminist "exaggeration" in persuading many young women that "they have been the victims of rape").

172. See Marcus, supra note 138 , at 395-97.

173. See Roiphe, supra note 7 , at 101 .

174. 1 draw this inference from the fact that neither Roiphe nor Paglia offers any remedial suggestion beyond the illumination of the proper perspective, nor acknowledges any difficulties women are likely to confront in embracing it.

175. Cf. Marcus, supra note 138, at 395-400 (highlighting contructedness of women's vulnerability, potential for women's agency, and supportive role to be played by law).

176. See supra text accompanying notes 106-124, n.124. 
of herself as a resourceful person or an effective parent. As contrasted with transcendent agency, internal agency is hard-won and almost always partial or incomplete. So long as coercion and devaluation of women continue in society, women must struggle with the tension between the "outside" and "inside" visions of themselves, ${ }^{177}$ or among the multiple voices that make up their identities. ${ }^{178}$ This insight is present in Keller's warning that the potentially transgressive messages implicit in pornography may sometimes reinforce dominant images, ${ }^{179}$ or Mahoney's description of battered women as moving between denial, confusion, and selfassertion. ${ }^{180}$ Yet the fact of the struggle itself, and the distinct self-conception that women are sometimes able to secure, distinguish these women from the wholly constructed subjects of dominance feminism.

Political agency occurs when a woman possessed of psychological agency uses her internal self-conception to fuel individual resistance or collective social change. This form of partial agency is highlighted particularly in the works of Mahoney and Keller. The woman who uses transgressive pornography to alter her own sexual relationships exercises political agency, as does the performance artist who uses pornographic representations to expose dominant sexual understandings. ${ }^{181}$ The battered woman who seeks counseling, demands a safer environment for her children, or risks separation abuse by trying to distance herself from her spouse also exercises political agency. Political agency is partial, not transcendent, because it is confined by social and structural constraints that complicate the path to action, and because it is impeded by women's own internalization of society's derogation. The battered woman may not yet feel able to live on her own; her lack of financial resources or her spouse's violent pursuit may force her to retreat back into the relationship. ${ }^{182}$ Yet as with internal agency, the struggles and partial victories that women are able to achieve give a different cast to the female subject. The illumination of these qualities by agency critics makes dominance theory a critical description, rather than a life sentence of injury and passivity.

2. The Role of the Law. - A second distinguishing feature of the agency critique is its comparatively rich portrait of the role of law in the social construction of gender. The sex radicals, as noted above, viewed law's role in shaping social norms as largely prohibitory. Its prohibitions might establish or reinforce social taboos; they could also prevent the proliferation of images that might shape such social constructs as gender. But a notion of law as a source of constructive imagery, rather than a

177. See Collins, supra note 107 , at $94-95$.

178. See Harris, supra note 117 , at $612-15$.

179. See Keller, supra note 125, at 2239-42.

180. See Mahoney, supra note 38 , at 1-10, 53-71.

181. See Keller, supra note 125, at 2241 (describing Madonna's transgressive sexual activity).

182. See Mahoney, supra note 156 , at $61-93$. 
source of permission or prohibition, does not emerge from the sex wars literature. While some agency critics remain focused on the impact of law's prohibitions, ${ }^{183}$ most proponents of the emerging critique modify these assumptions in a variety of ways.

Susan Keller, like her sex radical predecessors, is concerned primarily with the prohibitive function of the law. Yet she sees legal prohibitions as enabling, as well as discouraging, the transgressive force of women's reinterpretation. ${ }^{184}$ By loosening the connection between real life coercion and coercive representations, the "models and actors" provision of the MacKinnon-Dworkin Anti-Pornography Ordinance ${ }^{185}$ can free women to engage in the imaginative use of pornography that constitutes the most viable form of female resistance under current conditions. ${ }^{186}$

For Marcus, the law is also an adjunct to individual resistance strategies, but it contributes primarily not by its prohibitions, but by the imagery it introduces or reinforces. Its classification of rape as a form of assault, for example, may help women to see themselves as parties to "subject-subject violence" rather than as sites of sexual violation. Its depiction, in areas such as contract and property law, of women as actors capable of holding and exchanging property may help women to see themselves as self-directing subjects capable of resisting the "invagination"187 characteristic of the rape script. ${ }^{188}$

Like Marcus, Mahoney views law as a source of socially constructive imagery. But for Mahoney, such images assist women not by facilitating resistance, but by illuminating those forms of resistance that already occur. Mahoney shares with Harris the view that law must begin to accommodate a more complex subject: a subject whose "multiple voices" reflect the intersecting strands of constitutive influence in her life, and whose complexity consists in her paradoxical combination of self-determining impulses and internalized oppressive constraints. ${ }^{189}$ When laws adequately reflect this complexity, they help decisionmakers and the public to see resistance within oppression, rather than simply oppression. In addition, Mahoney highlights circumstances where law is not just a con-

183. Roiphe's and Paglia's resistance to university regulation might be viewed as an extension of the anti-regulatory thrust of the FACT Brief. See Paglia, supra note 6, at 50, 53 (describing "exaggera[ted] response by Universities to date rape" and stating that the "only solution to date rape is female self-awareness and self-control"); Roiphe, supra note 7 , at 69, 101 (deriding use of "rule, law .. . pamphlet or peer counseling group" to address date rape and advocating that sexually harassed women "deal with individuals with strength and confidence").

184. See Keller, supra note 125 , at 2226-39.

185. See MacKinnon-Dworkin Anti-Pornography Ordinance, supra note 5.

186. See Keller, supra note 125 , at 2229, 2232-33.

187. Marcus uses this unusual term to mean that "[t]he entire female body comes to be symbolized by the vagina, itself conceived of as a delicate, perhaps inevitably damaged and pained inner space." Marcus, supra note 138, at 398.

188. See id. at $397-98$.

189. See Harris, supra note 117 , at $612-15$; Mahoney, supra note 156 , at $1-10,53-71$. 
tributing factor to, but also a powerful influence on, social or cultural understandings. 190 The law of battered women's self-defense has been more than a background influence in shaping cultural images of battered women; its centrality underscores the need for the law to embody more complex images of women's lives.

Yet the law, particularly when it is conceived of as a source of imagery, is not always a force so easily directed or contained. While agency critics highlight the ways in which the law might be used constructively, theirs is by no means a narrative of inevitable progress. Their work is replete with examples of the law's detrimental effects, and they evoke a sense in which its social consequences cannot always be anticipated. Sharon Marcus's and Martha Mahoney's descriptions of the paradoxes of recent feminist legal victories provide a case in point. Feminist activists who emphasized rape law reform may have unwittingly contributed to the perception of rape's inevitability by demanding judicial solicitude to the experiences and sensibilities of rape victims. Similarly, proponents of the theory of "learned helplessness" may have sought to explain and justify battered women's self-defense, yet because they highlighted behavior of extreme passivity, which was then.mediated by longstanding stereotypes about domestic violence, this defense has also had a stigmatizing impact on battered women. The multiplicity of the messages that law communicates may itself be a source of difficulty in foreseeing or controlling its social effects.

\section{The Agency Critique and Feminist Legal Theory}

The distinguishing features of the emerging critique give it greater potential than its sex radical predecessor to engage the attention of feminist legal theorists. Whether it ultimately shapes the way legal feminists argue-either in scholarship or in the courts-will depend on the way that the critique is framed and translated into theoretical and doctrinal initiatives. This Part will explore these distinguishing features before turning to the more difficult question: What modes of presentation, doctrinal applications, and collateral inquiries seem most likely to bring the message of the new critique to legal theory and to law?

\section{A. The Content of the Critique}

The first feature of the critique that should incite jurisprudential interest is the shift in focus from women's pleasure to women's agency. Agency and pleasure occupy the opposite sides of a public/private divide that retains considerable organizing power in legal thought. ${ }^{191}$ Pleasure,

190. See Mahoney, supra note 156, at 34-43, 53-65.

191. For a thoughtful discussion of the persistence of this distinction and the way it affects gender and family issues, see, e.g., Frances E. Olsen, The Family and the Market, A Study of Ideology and Legal Reform, 96 Harv. L. Rev. 1497 (1983); see also Ruth Gavison, Feminism and the Public/Private Distinction, 45 Stan. L. Rev. 1, 2-4 (1992) (reviewing 
particularly sexual pleasure, is often viewed as a highly personal matter which the law can facilitate, if at all, only by staying its hand. The notion of agency, in contrast, is rich with potential legal associations. The attributes associated with agency are necessary not only to such intimate pursuits as sexuality, but also to the range of public activities that constitute commercial exchange or citizenship. ${ }^{192}$ These attributes are also implicated in responsibility for injurious acts targeted by tort and criminal law. These are attributes with which the law is likely to have more continuous engagement, and which legal actors can more legitimately claim to have an interest in fostering.

The legal interest generated by the "public" connotations of agency should be enhanced by a second feature of the critique: the fact that its account of partial agency challenges the dominant legal accounts of human subjectivity. As observed above, law tends most frequently to assume a simplified version of the liberal subject: a subject capable of uncompromised agentic self-determination, to whom legal authorities ascribe full responsibility for actions taken, and on whose behalf they are generally reluctant to intervene. ${ }^{193}$ The strength of these assumptions has often required lawyers seeking to depart from them to describe a sharply contrasting legal subject. ${ }^{194}$ In justifying legal intervention or a mitigation of legal sanction, lawyers have described, and judges have acknowledged, a female subject wholly incapable of self-direction, whom the law must rescue from her plight or relieve of responsibility for her

feminist analyses of the public/private distinction); Henry J. Friendly, Introduction: The Public-Private Penumbra-Fourteen Years Later, 130 U. Pa. L. Rev. 1289, 1289-95 (1982) (introducing papers on the Symposium on the Public/Private Distinction). It is not necessary to credit this dichotomy (in many contexts I don't) to believe that it will make the critique's concerns about agency interesting to legal theorists.

192. Even the private face of agency is associated with notions, such as reproductive autonomy, that trigger interventionist legal responses. Compare Planned Parenthood v. Casey, 112 S. Ct. 2791 (1992) (protecting reproductive autonomy, albeit under "undue burden" test rather than strict scrutiny) with Bowers v. Hardwick, 478 U.S. 186 (1986) (declining to extend legal protection to homosexual sodomy).

193. Anne Coughlin has recently highlighted this image of the responsible actor in the context of the criminal law in her discussion of the legal characterization of battered women. See Coughlin, supra note 55.

194. For a discussion of this pattern, see Mahoney, supra note 156, at 38-39. But see Coughlin, supra note 55, at 54-55. Coughlin argues that few women, in the eyes of the criminal law, ever conformed to the "model responsible actor"; women, particularly married women, were assimilated to a model of agency overcome by male influence, which Coughlin describes as the "model female actor." See id. at 24-29. My sense is that there are many areas of the law (rape and sexual harassment are prominent examples) in which the law measures women's behavior by a standard assuming characteristically male autonomy, thus suggesting that the second model of legal agency arose from an effort to defeat the strong assumptions of the first. However, it is possible that both my vision and Coughlin's are correct: women are sometimes assumed to be the same as men (and may distinguish themselves only by overstating their differences) and sometimes assumed to be different from men (most frequently when they are positioned as actors rather than victims), and both assumptions often work to their detriment. 
actions. The pragmatic interest of feminist lawyers in securing positive outcomes for their clients has often made them complicit in this dichotomizing tendency. They have stressed the extent of their clients' subordination and constraint in ways that have muted any capacity for self-direction or agency. ${ }^{195}$

Most forms of partial agency described above stand outside this Manichean view of legal subjectivity. Keller's contention that the social context of domination does not preclude interpretive resistance by potential victims, ${ }^{196}$ and Mahoney's particularized illustrations of the ways that protective self-direction coexists with intimidation and constraint,197 suggest a subject who is neither as unencumbered as the law's traditional subject nor as immobilized as the exceptional subject of the law's protection. If properly understood, these accounts not only have the potential to communicate new images of women living under conditions of oppression, but further to revise the imagery, assumptions, and even the outcomes reflected in several areas of gender-related law. ${ }^{198}$

195. See Coughlin, supra note 55, at 54-55; Mahoney, supra note 156, at 38-42.

196. See Keller, supra note 125, at 2229-33.

197. See Mahoney, supra note 156, at 1-10, 53-71.

198. Offering these new accounts of law and of women's lives is only one step on the road to potentially transformative results. The FACT Brief's, supra note 56, innovative characterizations were partially obscured when its authors offered a liberal gloss on their arguments, which readers embraced to the exclusion of competing implications. See supra Part II.B. It is necessary that these messages be framed in such a way that legal audiences can receive them without assimilating them to pre-existing conceptualizations.

Proponents should emphasize accounts of internal or political agency over transcendent narratives of progression from constraint to agency. Arguments such as Marcus's are intended to be empowering to women, and their emphasis on the real possibilities of achieving agentic resistance is intended to compensate for dominance accounts that describe resistance as unlikely or inexplicable. Yet they contain an implicit narrative of progress from greater to lesser constraint that may be misleading. They may be interpreted as suggesting that to understand the social constructedness of the feminine response to rape is to be able to act otherwise. They may also pay inadequate attention to the ways that this construction may continue to inhibit a woman's resistance, even if she understands it to be a construction. The emphasis of accounts such as Marcus's on the possibility of action for particular individuals may also be used to penalize women who are not (yet) able to act.

The sex radicals had a more sophisticated approach to such questions: they stressed the social constructedness of sexual norms and taboos but also documented the internal struggles that women experienced as they sought to challenge them. See, e.g., Allison, supra note 30 (detailing painful and tentative efforts by members of sexual minorities to acknowledge and get more information concerning non-normative sexual practices); Paula Webster, The Forbidden: Eroticism and Taboo, in Pleasure and Danger, supra note 3 (describing consciousness-raising group struggling to articulate forbidden acts of sexuality that members found appealing). Contemporary critics should learn from these multifaceted, non-linear characterizations. Their accounts should emphasize the hard-won, contingent character of women's agency and resistance under oppression by attending to two kinds of details in their depictions. First, proponents of the critique should strive to detail those material or attitudinal factors in women's lives that have tended to make selfdirection or resistance more or less likely. See Mahoney, supra note 156, at 19-24 (describing the many, often conflicting ways that the presence of children change the 
A final feature of the emerging critique that may engage jurisprudential attention is its sophisticated view of the role of law in shaping social norms and constructs. The sex wars critique, which viewed the regulation of pornography as interfering with the dissemination of transformative, non-legal imagery, had little to say about the relation between law and gender-related social norms. Law was the source of prohibitions that might structure behavior, but it was neither the engine of transformative change nor the source of socially salient imagery, good or bad. ${ }^{199}$ In the new critiques these assumptions have been substantially revised: law retains its role as a potentially prohibitory force though its prohibitions may also be the source of feminist transformation as well as of conservative retrenchment. More importantly, however, law has been revealed as one of the many social practices whose images, narratives, and depictions contribute to the formation of social constructs. This role is not limited, as the FACT Brief implied, to the perpetuation of stereotypes that interfere with rational decisionmaking. ${ }^{200}$ Socially constructive images may be communicated through law's explicit prohibitions, but they may also be communicated in a range of subtler ways: through the kinds of narratives that are taken to justify claims of self-defense; through the accounts of injury that are taken to be authoritative in granting recovery; by the subtle glosses that courts impose on depictions of victimization; or by the features or phases of particular social problems on which legal decisionmakers choose to focus. This critical account of the role of law poses a potent challenge to traditional legal theorists who have traced law's social influence to its prohibitory force. It also confronts an audience with a more direct interest in its substantive message: feminist and other legal reformers who have too readily assumed that the legal intervention they seek communicates a single message about female claimants or about gender. This account challenges feminist reformers to see the many ways in which a legal rule or claim may influence norms regarding gender, often escaping the intentionality of its framers.

calculations of a battered woman). Such accounts highlight the reflective processes of women contemplating agentic or resistant action in an oppressive context, clarifying both the inclination toward resistant self-direction and the factors that shape a woman's ultimate judgments. Second, proponents can document the ambivalence of women as they try to assert themselves against their own, internalized constraints. See Mahoney, supra note 156, at 49-53; Allison, supra note 30, at 103-05. Agency and resistance under oppression cannot help but be difficult and contingent; depictions that illuminate these characteristics with concreteness and detail are likely to be most effective in introducing audiences to this paradoxical state.

199. See supra text accompanying note $\mathbf{5 0}$ (describing sex radicals' view of law as prohibition rather than source of social imagery). text.

200. See FACT Brief, supra note 56, at 102-05; supra notes 58-69 and accompanying 


\section{B. Applying the Critique}

Engaging the attention of the legal community is an important goal, as the mixed legacy of the sex radical critique suggests. Yet, with a critique as varied in normative standpoint as the agency critique, proponents must also decide how they want to direct this attention once they claim it. In narrating the emergence of the agency critique, I attempted a more inclusive and less tendentious presentation, highlighting works with which I substantially disagree and emphasizing exposition over my substantive reservations. As I turn to questions of application, however, it seems appropriate that I make explicit what was largely implicit in the foregoing discussion: the version of the agency critique that I believe best reflects the circumstances and serves the political and legal needs of women in this society.

This version of the agency critique affirms the central premise of dominance feminism: that women suffer systematic oppression in which sexualized domination by men plays a crucial role. It does not, like Paglia, ${ }^{201}$ revere male sexuality as a blameless, immutable life force, nor does it, like Roiphe, ${ }^{202}$. see women's oppression as a problem that exists largely in feminists' heads. It also shares the constructivist thrust of dominance theory: women are not simply impeded (as some sections of the FACT Brief imply ${ }^{203}$ ) but actually shaped-in their fears, tastes, and choicesby sexualized oppression. This means that resistance to those forces of oppression, whether internal or outwardly focused, will inevitably be difficult or partial: few women can expect to achieve the disruptive transcendence of oppressive norms that Marcus describes. ${ }^{204}$ Yet this critique takes issue with dominance theory for its often-strategic repression of the possibility of such resistance. This muting of the agency theme in dominance-based accounts of the female subject ${ }^{205}$ provides an incomplete picture of contemporary women's lives, and may cause its message to be manipulated by opportunistic critics, or misunderstood by potential allies, such as the courts. This version of the agency critique seeks to highlight this repressed element through a respectful supplementation of dominance theory. It does so with an eye to averting these misunderstandings, crediting those self-directing steps that women have already taken, and encouraging further resistant exploration.

Bearing in mind this account of women's agency under oppression, the next question is how proponents of the critique should apply these

201. See Paglia, supra note 6 , at 53.

202. See Abrams, supra note 10, at 1548 (assessing Roiphe as "see[ing] sexual coercion as a problem in women's heads").

203. See FACT Brief, supra note 56 , at 134 .

204. See Marcus, supra note 138, at 391-96. Interpretation can indeed be a source of women's power, but it requires more collective implementation than Keller suggests, and more legal reinforcement than either Keller or Marcus seems to require.

205. See supra Part III.A (discussing strategic muting of agency theme in MacKinnon). 
revised images. What should the law do-or do differently-to better reflect the partial agency of women?

It seems unlikely that a commitment to depicting women's partial agency would lead to a single or unified type of legal or political program. Even agency critics of the type just described may be too diverse in their views of the role of law in enhancing women's power to agree on a uniform strategy. Moreover, a critique that takes as a central premise the variety and unpredictability of law's social effects would be unlikely to orient itself around a single legal strategy or even a finite set of strategies that could be articulated in advance. Like dominance theory, which it supplements or recasts, the agency critique would seem to point toward a strategic or pragmatic approach ${ }^{206}$ that addresses particular controversies as they arise, in light of more generally shared goals. In this case, the goal would be to depict women as possessing a constrained but nonetheless salient capacity for self-direction, while addressing the underlying conditions of women's oppression.

In an effort to clarify some practical consequences of the agency critique, while preserving the strategic flexibility that I expect to be its hallmark, I will consider a range of remedial approaches that might be embraced by agency theorists of the type I describe above. I will classify these approaches by the type of strategy they involve-the particular use that they propose to make of legal rules and/or imagery-rather than by the area(s) of substantive law to which they apply. However, under each category I will consider arguments within particular areas of legal doctrine that have been made in the past, or might be made in the future, to implement the approach under consideration. I will then assess the

206. Because dominance theory, as developed by Catharine Mackinnon and Andrea Dworkin, has become so strongly associated with particular legal responses such as the regulation of pornography or sexual harassment, it may be difficult to conceive of it as strategic or pragmatic in its orientation toward remedying women's oppression. However, there is nothing about the legal regulation of particular sexually objectifying practices that flows inexorably from MacKinnon's critique, particularly as that critique deeply implicates legal doctrine, legal reasoning, and legal decisionmakers in women's oppression. MacKinnon must, in fact, address these defects by displacing legal neutrality with perspectival reasoning before she can hope to establish law as a viable remedy. And even having modified legal reasoning, her approach must still confront the intransigence of legal decisionmakers. See, e.g., MacKinnon, Feminism Unmodified, supra note 17, at 220 (describing her continued faith in women judges as "a triumph of hope over experience"). Moreover, as the varied essays of Feminism Unmodified reveal, MacKinnon has many remedial strategies beyond statutory regulation of sexualizing practices that she fashions in a more flexible manner in response to the needs of women in particular circumstances. See, e.g., id. at 117-24 (describing women's athletics as giving "us a sense of an actuality of our bodies as our own, rather than primarily as an instrument to communicate sexual availability"); id. at 83 (instructing male supporters of women rallying against rape how to "support [ ] us ... without taking over either our injuries or our pleasure"). It is worth noting, however, that dominance theorists do not emphasize the variety or unpredictability of law's social effects to the same extent that agency critics do. This may be a legacy of the two movements' distinct theoretical underpinnings: dominance theory was influenced by structural social theory while some agency critics were shaped by poststructuralism. 
promise and the dangers inherent in each approach. These strategies should serve not only to implement the agency critique, but also to apply certain insights of the sex radicals: insights that extend beyond FACT's opposition to the regulation of pornography, but which were diffused by the sex radicals' limited familiarity with the operation of the law. ${ }^{207}$

The strategies I will consider fall into five categories. The first uses law in a minimal sense to enhance the safety of the transgressive explorations undertaken by individual women. This strategy enacts the view of Keller and Marcus that women may enhance their power by exploring historically oppressive practices in order to expose and reinterpret them; it also suggests that law can facilitate such action by mitigating the most obvious dangers of these explorations. The second and third approaches, discussed below under a single heading, look to law as a vehicle for communicating women's partial agency. The second focuses on legal claims-usually for sexualized injury-in which showing resistance is a predicate to legal intervention; it expands the resources available to women to demonstrate resistance by encouraging them to use indicia of partial agency to demonstrate resistance in certain kinds of claims. The third strategy focuses on dominance-based claims for legal relief and attempts to revise the elements of such claims that communicate subordinating images of women.

The fourth category is not a strategy I would prescribe, but a legal approach that is likely to be proposed, particularly by critics of partial agency. This response suggests that the revelation of women's agency, even under circumstances of oppression, points to a diminished need for legal intervention on behalf of women. In this section I explain why a contraction of legal intervention need not and should not follow from the revelation of partial agency I describe. However, the possibility that some legal audiences will see a tension between women's capacity for selfdirection and women's entitlement to gender-specific forms of legal relief points to a fifth strategy. This final strategy would involve challenging or modifying legal rules that contribute to a dichotomous characterization of women's legal subjectivity-ordaining legal intervention or mitigation for those who lack the capacity to act for themselves, and denying legal relief to those who demonstrate agency or responsibility.

1. Using Legal Regulation to Facilitate Women's Subversive Explorations As the sex radicals and Susan Keller observe, some activities that may be viewed as threats to women's well-being may also be described as opportunities for women to challenge conventional norms and explore elements of their experience constrained by taboos and social expectations. While this characterization may not apply to gender-specific injuries such as

207. The problem with the sex radical critique, from the standpoint of long-term legal impact, may have been that it was not presented in a way that made evident to legal readers its apphication to a range of practical legal controversies. The problem may also have been that it was applied repeatedly to a particular controversy that legal scholars either tended to ignore or, incorrectly, to treat as sui generis. 
rape or domestic violence, it may apply to practices such as the production and use of pornography. In this view, it may be shortsighted for women to turn their backs on all practices that have been instrumental to their collective subordination. ${ }^{208}$ It is preferable for individual women to explore these practices so that they can understand not only the assumptions that underlie them and the representations of which they are composed, but also how both have been mobilized to effect women's subordination. It is then important for women to place their own distinctive mark on these practices, to reshape them in ways that are not premised on subordinating assumptions.

To the sex radicals, for whom a belief in social construction mixed unpredictably with a belief in sexual authenticity, ${ }^{209}$ this reshaping produced not so much a commentary on the original practices as an alternative undistorted (or less distorted) by the force of dominant sexual norms. ${ }^{210}$ For Keller, the strategy sought to recast subordinating practices in ways that exposed their assumptions or modified their representations so as to problematize the originals. Keller gives, as an example of this strategy, the quasi-pornographic videos made by Madonna, which call into question the naturalness and stability of gender roles through the use of drag or other sexual role reversals. ${ }^{211}$

Judith Butler has described this strategy as the subversive repetition of dominant images or norms. This practice, she explains, is

neither an efficacious insurrection nor a painful resubordination, but an unstable coexistence of both .... [It is] not an appropriation of dominant culture in order to remain subordinated by its terms, but an appropriation that seeks to make over the terms of domination, a making over which is itself a kind of agency, a power in and as discourse, . . . which repeats in order to remake-and sometimes succeeds. ${ }^{212}$

208. See Keller, supra note 125, at 2229 (describing Butler's view that efforts to completely eliminate subordinating practices "divert energy from the more important task of working within the socially constructed world").

209. Those sex wars writers who focused on sexual taboos seemed to suggest both that social norms are constructive of our sexuality and that it may be possible to "get beyond" them to some unconstrained state. See, e.g., Webster, supra note 32, at 385-98 (exploring how one group of women sought to defeat, by exposing and confronting, their own sexual taboos). In addition, those writers whose essays invoked a narrative of personal progress from greater to less constraint by social norms, seem to suggest both the social construction of sexuality and the possibility (and value) of transcending it. See, e.g., Hollibaugh, supra note 26, at 401-10 (offering narrative of personal sexual liberation).

210. There are exceptions to this generalization. A few of the sex wars writers, such as Joan Nestle, seemed to anticipate the subversive repetition strategy discussed below. See Nestle, The Fem Question, supra note 29, at 232-41 (describing butch/femme roles not as replication of but as problematizing commentary on male/female roles in heterosexuality).

211. See Keller, supra note 125, at 2237; Franke, supra note 131, at 566.

212. Judith Butler, Bodies That Matter 137, 138 (1993). 
While Keller generally endorses this approach, she sees subversive repetition as a high-wire act that should not be performed without a net. The attempt at restatement may in fact reinforce dominant norms, causing harms unanticipated by the subversive actor. ${ }^{213}$ The law, Keller argues, may help to control this risk by regulating those aspects of the practice most likely to result in harm to women. In the area of pornography, this means using law to loosen the connection between "viewing" and "doing": if the actresses and models provision of the MacKinnon-Dworkin Anti-Pornography Ordinance assures women that the creation of pornography was not the occasion for the coercion of real women, they may feel more comfortable investigating and reinterpreting pornographic representations. ${ }^{214}$

A similar legal strategy might be employed in the area of surrogacy. Surrogacy, like pornography, is a practice with the potential to coerce or exploit individual surrogates, as well as to reinforce negative social images of women as natural mothers ${ }^{215}$ or as commodities.216 However, surrogacy also has the potential to challenge dominant expectations regarding women's relation to their reproductive capacity, and the definition and genesis of families, in ways that may be beneficial to women. Carmel Shalev has argued, for example, that by permitting women to contract and thereby direct the use of their reproductive labor, surrogacy might communicate self-determining images of women that would in turn shape social conceptions. ${ }^{217}$ Noah Zatz, in a poststructural analysis similar to Keller's, endorses surrogacy as a form of subversive repetition. ${ }^{218}$ Though he believes that surrogacy could be characterized or practiced in

213. See Keller, supra note 125, at 2239-41 (transformative potential of pornography lies in use of very images that make it dangerous; danger is only partially mitigated by legal controls).

214. See id. at 2237 (citing Duncan Kennedy as saying "abolishing real life male sexual abuse of women would reduce the dangerousness of" using costumes and fantasies for both pleasure and resistance). As I note supra note 136, it seems to me that if Keller is concerned with making subversive repetition as unlikely as possible to result in physical harm to women, she should endorse not only the actresses and models provision, but the provision creating a cause of action for assault with pornography. In a sense, the actresses and models prohibition encourages women to experiment or subvert, and the anti-assault provision mitigates the dangers that can be created through the use of subversive pornography, or through the use of conventional pornography that continued to flourish because women did not wage a political effort to curtail it.

215. While the image of a natural mother (one who intuitively knows how to nurture a child) is not in itself a negative one, the suggestion that it is broadly applicable to women may have negative consequences. The social tendency for the "natural" to be construed as the normative may make this understanding prejudicial or confining to women who are not natural mothers, or seek to do other things with their lives.

216. For critiques of the social effects of legalizing surrogacy arrangements see, e.g., Elizabeth Anderson, Is Women's Labor a Commodity?, 19 Phil. \& Pub. Aff. 71 (1990); Andrea Dworkin, Right-wing Women 181-88 (Perigee Books 1983).

217. See Carmel Shalev, Birth Power 146-66 (1989).

218. See Noah Zatz, Re-Working Motherhood: Surrogacy, Labor and the Family 257 (1994) (unpublished manuscript, on file with Columbia Law Review). 
ways that would make it commodifying or maternalizing for women, he also believes it could be practiced in ways that would problematize dominant social norms relating to women, work, and family. Conceiving, gestating, and delivering a child as paid labor for a family not one's own would expose and challenge conventional notions of pregnancy (as undertaken altruistically and aimed at reproduction within one's own family), the divide between work and family (as practically and morally unbridgeable), and the definition of "family" (as a nuclear unit consisting of a cross-sex couple with biological children). ${ }^{219}$ For Zatz, surrogacy becomes more likely to challenge dominant norms if it is "articulated to" (that is, socially and legally connected with) wage labor, and more likely to reinforce dominant norms if it is articulated to parenting. ${ }^{220}$ Although Zatz, writing as a political theorist, does not explore the legal regimes that might vindicate this goal, one could imagine legal regulations that would be aimed at making surrogacy less risky in these ways. ${ }^{221}$ Requiring that workers' compensation schemes attaching to traditional forms of labor be applied to surrogacy might help to articulate surrogacy to wage labor. Requiring enforcement of surrogacy contracts, with only limited accommodation of the possibility of maternal bonding by the surrogate, might help to de-couple surrogacy from the potentially restrictive norms of parenting. Secured in such ways against the most obvious dangers of exploitation or of reinforcing traditional norms, women might feel free(r) to experiment with the subversive potential of surrogacy.

Subversive repetition is in some ways an appealing strategy, particularly for exponents of women's partial agency. It is a promising expression of optimism about the capacity of the individual to resist subordination, even within the confines of a socially constructed world. It offers a liberating expansion and diffusion of the political realm:222 political

219. See id. at 6-19.

220. See id. at 197-99.

221. Aside from a passing suggestion that workers' compensation schemes might be useful in articulating surrogacy to wage labor, see id. at 197, the following improvisations on Zatz's more general proposal are my own. I have no idea whether he would subscribe to them himself. I would also stress that they are very general suggestions aimed at demonstrating how law might be used to mitigate the dangers of a subversive approach to surrogacy. Particularly given the reservations 1 express about subversive repetition as a strategy, see infra text accompanying notes 223-225, I do not offer these as my ultimate prescriptions for what should be done in the surrogacy area.

For a more systematic examination of surrogacy that reaches normative conclusions, instead of advancing exploratory positions, regarding its legal regulation, see Margaret J. Radin, Market-Inalienability, 100 Harv. L. Rev. 1849, 1928-36 (1987).

222. For works in recent radical democratic theory that describe this expansion and diffusion, see Kirstie McClure, On the Subject of Rights: Pluralism, Plurality and Political Identity, in Dimensions of Radical Democracy 108, 123 (Chantal Mouffe ed., 1992) (describing expansion of the political to include economic transactions, sexual relations, and interactions in educational institutions and on the street); Rosemary Coombe, Tactics of Appropriation and the Politics of Recognition in Late Modern Democracies, 21 Pol. Theory 411 (1993) (describing consumer choices and appropriation of commercial slogans as political activity). 
resistance becomes an act that can sometimes be practiced within the privacy of one's own home. Yet, to my mind, there is also room for doubt about its ultimate efficacy and its risks.

It is a strategy whose central activity-the repetition itself-places the acts of an individual in opposition to the accumulated force of entrenched norms. This approach seems significant if one sees dominant norms as becoming so pervasive and internalized that alternate positions are not simply eclipsed but unspeakable or unintelligible. ${ }^{223}$ Under such circumstances, a single voice speaking the previously unsayable becomes a salient political victory. However if one views dominant norms as making their opposition appear partial or implausible, but not wholly unspeakable or unintelligible, the atomized, individual character of this genre of resistance may seem more problematic.

There may also be a limit to the political impact of a series of uncoordinated subversive interpretations. While reinterpretation of pornography might allow individual women to explore unattended or tabooed facets of their sexuality, such explorations, unstructured by any larger collective effort, would hold little promise of mitigating the numerically and culturally dominant force of conventional pornography. Finally, the law may be unable to secure women against many negative consequences of subversive repetitions. Individuals engaged in subversive repetition may have to rely on others, including pornographic filmmakers or adoption middlemen, who subscribe to more oppressive interpretations of the practices in question; these actors may not be adequately controlled through the minimalist forms of regulation discussed above. And legal regulation, in any form, offers no guarantee that interpretations that aim to be subversive will not be understood in ways that reinforce dominant norms. This problem might be particularly acute in the area of surrogacy, for example, where the maternalization of women-and the perpetuation of maternal images specific to race and class-have survived several phases of legal reform, and might well survive an attempt to articulate surrogacy to wage labor. ${ }^{224}$ Subversive repetition offers a com-

223. This understanding of dominant norms is elaborated by Pierre Bourdieu. See Pierre Bourdieu, The Force of Law: Toward a Sociology of the Juridical Field, 38 Hastings L.J. 805, 848 (1987). Bourdieu uses law as an example of a source of dominant norms in contrasting the notion of "orthodoxy" with that of "doxa":

The law, an intrinsically powerful discourse coupled with the physical means to impose compliance on others, can be seen as a quintessential instrument of normalization. As such, given time, it passes from the status of 'orthodoxy,' proper belief explicitly defining what ought to happen, to the status of 'doxa,' the immediate agreement elicited by that which is self-evident and normal. Indeed, doxa is a normalcy in which realization of the norm is so complete that the norm itself, as coercion, simply ceases to exist as such.

Id. Norms that have entered the status of the "doxa" are not simply familiar or compelling; they appear self-evident and natural, rendering other possibilities unintelligible.

224. A recent historical study of the treatment of Black and white single mothers in the post-World War II era demonstrates that many of the characterizations of Black women and white women as mothers that were prevalent during that period continue to have 
pelling symbol of the power of the socially situated individual to resist thoroughgoing social construction, but it may be more effective when used, in localized fashion, to foster the internal agency of women than to produce more systematic political change.

2. Combatting Polar Imagery in Legal Claims Involving Sexualized Injury - A second pair of approaches draws on the perspective advanced by Martha Mahoney: feminists should make visible the subtle, unnoticed instances of resistance that characterize women's lives and prevent the imposition of legal rules that either obscure or undermine such resistance. These approaches take their bearings from a paradox that has emerged in litigation over sexualized injuries. Women bringing claims of sexual harassment, or pressing charges of rape, for example, are often required to demonstrate resistance of a type that would be characteristic of a largely autonomous, physically and politically empowered individual. Yet even where claimants are able to approximate such showings, other elements of the claim-such as the evidence that is taken to establish injury or the qualities that are ascribed by fact-finders to "legitimate" victimsproject a different vision. These elements assume, and perpetuate images of, victims who are impaired, wholly vulnerable, or incapacitated by the conduct in question. Courts adjudicating these elements may penalize a claimant if she departs too much from these assumptions; but they may also grant victory to the individual claimant while the legal image connected with that victory propagates stigmatizing images of women. The partial agency strategy proposed here would address both parts of this problem.

The first approach seeks to ameliorate inappropriate resistance requirements. By highlighting the ways in which many oppressed women express resistance-ways that may not have been adequately acknowledged-agency critics might expand the range of showings viewed as sufficient to demonstrate the unwelcome character of the conduct. The second approach seeks to address elements of legal claims that either require women to demonstrate, or more implicitly communicate, thorough incapacitation. In this context, agency critics would call for images indicating that women may be injured without being wholly devastated by

force today, notwithstanding the intervening effects of several "generations" of feminist legal and social change. Compare Rickie Solinger, Race and "Value": Black and White Illegitimate Babies, 1945-65, in Mothering: Ideology, Experience, and Agency 287, 290-93, 297-304 (Evelyn N. Glenn et al. eds., 1994) (in Post-World War II period, white unmarried pregnant women had recourse to heavily regulated abortions, or could place clildren for adoption, while Black single mothers were stigmatized as irresponsible, and were expected to raise their 'socially burdensome' children) with Jane M. Cohen, A Jurisprudence of Doubt: Deliberative Autonomy and Abortion, 3 Colum. J. Gender \& L. $175,186-88,204-05$ (1992) (abortion still an option for single white mothers thougl severely constrained by state regulations and medical paternalism) and Dorothy $\mathrm{E}$. Roberts, Punishing Drug Addicts Who Have Babies: Women of Color, Equality, and the Right of Privacy, 104 Harv. L. Rev. 1419 (199I) (Black single mothers still perceived as irresponsible women who produce socially burdensome offspring). 
sexualized conduct. The two sides of partial agency merge to create a coherent whole with this strategy: by suggesting that women are neither wholly empowered, nor wholly incapacitated, in those contexts where they are targets of sexualized conduct, agency critics can combat the legally injurious and politically demoralizing features of current legal remedies.

a. Using Indicia of Partial Agency to Demonstrate Resistance, Where Resistance is a Predicate to Legal Intervention. - In a society that still assumes that sexualized behavior will be viewed positively by its target, resistance is used by legal fact-finders as a means of distinguishing acceptable from unacceptable conduct. ${ }^{225}$ The prosecution in a rape case must prove non-consent, so as to distinguish rape from consensual sexual intercourse. ${ }^{226}$ Similarly, the plaintiff in a sexual harassment case must demonstrate more than pervasive, sexually-based behavior in a work setting; she must also demonstrate that the sexual conduct or talk was "unwelcome," so as to distinguish it from the kinds of ostensibly harmless sexual interplay thought to exist in most workplaces. ${ }^{227}$ Informed by a

225. Both the non-consent element of a rape charge and the unwelcomeness requirement in a claim of sexual harassment are premised on the assumption that sexual overtures-even between strangers or in non-social settings such as the workplace-are presumptively benign (i.e., non-coercive) and are welcomed by their target until proven otherwise. In addition, both showings have the potential to transform a claim of sexualized injury into a "trial of the victim." See Susan Estrich, Sex at Work, 43 Stan. L. Rev. 813, 828 (1991) (arguing, in part, that "unwelcomeness" showing in sexual harassment claims may focus legal decisionmakers' attention on a woman's conduct in much the same way that non-consent showing does in rape cases). I, therefore, have grave reservations about the inclusion of these elements in their respective claims. However, I believe it is extremely unlikely that either requirement will be eliminated in the foreseeable future. Thus, I think it is important to consider how these requirements might be modified so as to make them minimally burdensome to women claimants. My willingness to focus on the content of these requirements should be taken as a pragmatic resolution to work with gender-related law as we find it, not an endorsement of what $I$ view as the objectionable and ungrounded assumptions underlying these elements. For a more comprehensive attempt to reformulate sexual harassment doctrine in order to combat women's oppression and encourage the flourishing of women's sexuality, see Drucilla Cornell, supra note 105. I view Cornell's analysis, which recasts the standards for evaluating sexual harassment to eliminate the "unwelcomeness" requirement and the use of perspective in defining the harm of sexual harassment, as a brilliantly resourceful effort to reconcile these apparently disparate goals, although I am less sanguine than she about the capacity or willinguess of the courts to accept so thoroughgoing a reconceptualization.

226. As Lynne Henderson and Steven Shulhofer have observed, some states have redefined rape to be forcible intercourse, dropping any explicit non-consent requirement. See Henderson, supra note 128, at 63-64; Steven J. Shulhofer, Taking Sexual Autonomy Seriously: Rape Law and Beyond, 11 Law \& Phil. 35, 39 (1992) (citing Michigan law which emphasizes force rather than non-consent). As Susan Estrich has observed, however, force is often defined not as the force "incidental to the act of intercourse," but as the force necessary to overcome a woman's resistance. Susan Estrich, Rape, 95 Yale L.J. 1087, 1107 (1986). Thus, even in a force-oriented jurisdiction, the extent of a woman's resistance becomes an issue to be established by the prosecution.

227. See Meritor Sav. Bank v. Vinson, 477 U.S. 57, 65, 68 (1986). The courts have used a five-part test for proving hostile environment sexual harassment. The plaintiff must 
premise of unencumbered interaction among equals, and a model of resistance expressed by blunt objection or bodily force, the requirements imposed on women claimants in demonstrating resistance have often been stark. By familiarizing fact-finders with the modes of resistance characteristic not of liberal subjects or dominant men but of oppressed women, exponents of partial agency might render these requirements less onerous.

Susan Estrich has documented the slow, incomplete evolution of the requirement of non-consent in rape cases. Courts gradually abandoned the requirement that the prosecution demonstrate "utmost resistance,"228 reasoning that women should not be obliged to place their lives in danger in order to be able to supply the elements of a rape charge. 229 Although contemporary fact-finders no longer require utmost resistance, many still require some evidence of physical resistance, regarding a woman's spoken "no" as an insufficient or unreliable index of her opposition. ${ }^{230}$ Estrich has urged fact-finders to consider as indicia of non-consent a woman's word "no" or her shedding of tears during the course of the assault. ${ }^{231}$ To this list might also be added women's efforts to bargain for a change in the location of the assault or type of sexual act proposed.232 Courts and juries have reflected ambivalence about the effect of evidence that the victim sought to negotiate, particularly in an unin-

demonstrate that: 1) she is a member of the protected class; 2) she was subjected to unwelcome sexual harassment in the form of requests of sexual favors or other verbal or physical conduct of a sexual nature; 3) the harassment was based on sex; 4) the harassment unreasonably interfered with the plaintiff's work performance and created an intimidating, hostile or offensive work environment; 5) there is respondeat superior liability on the part of the employer. See Rabidue v. Osceola Refining Co., 805 F.2d 811, 819-20 (6th Cir. 1986), cert. denied, 481 U.S. 1041 (1987); Henson v. City of Dundee, 682 F.2d 897, 903-05 (11th Cir. 1982). See also Meritor Sav. Bank v. Vinson, 477 U.S. at 63-68.

228. See Estrich, supra note 226, at 1122-25. This entailed, in the view of one court, "the most vehement exercise of every physical means or faculty within the woman's power to resist the penetration of her person." Id. at 1123 (quoting Brown v. State, 106 N.W. 536, 538 (Wis. 1906)).

229. See id. at 1123 n.110.

230. See id. at 1124-32.

231. See id. at $1093,1111,1179-84$.

232. These forms of negotiation might be seen as an area of intersection between Mahoney's vision of the incremental, pragmatic resistance of oppressed women, and Marcus's vision of script-disruptive resistance. See Marcus, supra note 138, at 396. Factfinders might also consider as evidence of non-consent other forms of script-disruptive resistance described by Marcus such as chiding or deriding the assailant. See id.

While Marcus is clear in saying that such conduct should not be required of rape victims in order to make out a case of non-consent, id. at 393, I do not take her argument to suggest that such evidence could not be offered, if it were used in a non-exclusive fashion (i.e., lack of such evidence does not establish consent). Of course, the difficulty would be making sure that it was accepted without making it a predicate for success by the prosecution. For more on the problem of newly highlighted resistant activity being used against women claimants, see infra note 238 and accompanying text. 
timidated fashion, with the accused. ${ }^{233}$ Yet these responses are consistent with the kinds of resistance highlighted by Mahoney: not the straightforward dissent of a fully empowered actor, but the subtle, selfpreserving moves of one who understands her social and situational constraint.

In the area of sexual barassment, plaintiffs are obliged to demonstrate the unwelcomeness of defendant's sexual conduct. Courts have varied widely in the types of evidence they take to be persuasive on the issue of unwelcomeness. Although some courts adjudicate the issue as a question of plaintiff's credibility 234 - her word that she found the conduct offensive is the primary evidence-more courts find that the issue becomes more complicated. Most courts are willing to consider a range of showings by the defendant offered to suggest that the plaintiff found the conduct acceptable. Meritor Savings Bank v. Vinson ${ }^{235}$ held that evidence regarding plaintiff's clothing, demeanor, and language in the workplace was relevant to the question of unwelcomeness. ${ }^{236}$ Other courts have considered evidence regarding the plaintiff's social and sexual proclivities outside the workplace. ${ }^{237}$ Although these courts have not explicitly required plaintiffs to demonstrate contemporaneous objection or other obvious verbal indicia of unwelcomeness in order to prevail, such evidence can be crucial in refuting the inferences drawn from defendant's language and demeanor evidence. In addition, where plaintiff's inability to show visible resistance does not defeat her claim of unwelcomeness, it may be applied to defeat another element of the bostile environment claim: the requirement that she demonstrate harassment pervasive enough to constitute a hostile environment. ${ }^{238}$ Courts some-

233. In a much-publicized case in Austin, Texas, a woman was raped at knife-point by a stranger who entered her house. During the course of the assault, she asked the assailant to wear a condom that she provided in order to protect against AIDS. Although the man subsequently confessed, he stated, "[t] here was no rape to it. She's the one who gave me the condoms. If she didn't want to, why would she give me the condoms?" Henderson, supra note 128, at 67 (citation omitted). The first grand jury convened to hear the case failed to indict, after a hearing at which the prosecution did not call the victim to testify. See id. (citing Kimberly Garcia, Grand Jury Decides Not to Indict on Rape Charge, Austin Am. Statesman, Oct. 9, 1992, at A1). A second grand jury ultimately indicted. But see Body v. State, 630 A.2d 1102 (Del. 1993) (affirming conviction of defendant after victim had offered verbal resistance and asked defendant to wear condom).

234. See Zowayyed v. Lowen Co., Inc., 735 F. Supp. 1497, I504-05 (D. Kan. 1990) (holding that issue of unwelcomeness turns on credibility determinations, and denying summary judgment for defendant where plaintiff asserted that conduct caused her pain and anguish); Morris v. American Nat. Can Corp., 730 F. Supp. 1489, 1495 (E.D. Mo. 1989) (holding conduct unwelcome, despite plaintiff's own use of profane language, where plaintiff "expressed distate for [sexually exphicit] items and materials she received [from coworkers] and ... embarrassment at the language she endured").

235. 477 U.S. 57 (1986).

236. See Vinson, 477 U.S. at 69.

237. See Burns v. McGregor Electronic Industries, 955 F.2d 559, 565 (8th Cir. 1992).

238. Although the Vinson standard formally requires plaintiffs to show both unwelcomeness and "pervasiveness" - the requirement that the conduct be sufficiently 
times take a plaintiff's failure to object as evidence that the harassment was not bad enough to be actionable.

One reason for plaintiffs' difficulties with unwelcomeness or pervasiveness claims is that courts-where they have explicitly or implicitly required them - have focused on a limited set of showings as demonstrative of unwelcomeness. Many courts look for timely verbal objection, ${ }^{239}$ dramatic efforts to escape the perpetrator, ${ }^{240}$ or harm to plaintiff's psychological well-being. ${ }^{241}$ Agency critics might argue, in contrast, that women make many efforts to resist and extricate themselves from harassing environments, few of which involve direct objection. Women confronted with workplace harassment most commonly try to short-circuit or extricate themselves from the behavior through jocularity, changes in subject, or efforts to avoid the perpetrator. ${ }^{242}$ That such efforts are not always successful in curtailing the harassing conduct, and that they do not represent the straightforward frontal assault characteristic of the unsubordinated subject, should not, critics might argue, make them irrelevant to the issue of unwelcomeness. These are the ways in which women under oppressive conditions seek to secure themselves from offensive conduct while preserving their employment opportunities and livelihood. ${ }^{243}$ Making these constrained forms of resistance visible in the con-

hostile or abusive to create a hostile environment-some courts place their emphasis on unwelcomeness and some on pervasiveness. As in the rape example, some courts may treat the "unwelcomeness" requirement itself as a pro forma matter, as to which they accept the plaintiff's assertions that she found the conduct offensive, without more; but some of those courts impose a strenuous pervasiveness requirement, which functions as a sort of proxy for the showing of unwelcomeness. The suggestion, made under the auspices of pervasiveness, is that the conduct could not have been bad enough to impose legal sanctions because the plaintiff did not object to it, or took a long time to object to it. See, e.g., Harris v. Forklift Sys., Inc., 60 Empl. Prac. Dec. (CCH) II 74,245, 74,248 (M.D. Tenn. 1990), rev'd, 114 S. Ct. 367 (1993) (crediting plaintiff's claims of unwelcomeness but using her failure to make prompt objection as evidence of lack of pervasiveness).

239. See, e.g., Harris, $60 \mathrm{Empl}$. Prac. Dec. at $174,250$.

240. See, e.g., Brooms v. Regal Tube Co., 881 F.2d 412 (7th Cir. 1989) (finding unwelcomeness where plaintiff fell down flight of stairs trying to escape defendant).

241. After Harris, $114 \mathrm{~S}$. Ct. at 371 , this showing is no longer required as a sine qua non of recovery. However, the Court acknowledged that it would continue to be relevant to a finding of pervasiveness. See id. at 371.

242. See Louise Fitzgerald et al., Why Didn't She Just Report Him? The Psychological and Legal Implications of Women's Responses to Sexual Harassment, J. Soc. Issues (forthcoming 1995), at 3-4 (reviewing studies suggesting that approximately $50 \%$ of employed sexual harassment victims use avoidance strategies, while other common strategies involve the use of humor or efforts to "put off" the harasser).

243. One might describe this approach as adopting a "reasonable woman's" perspective on the question of unwelcomeness, much as some courts have adopted a "reasonable woman's" perspective on the question of pervasiveness. Although such gender-specificity in perspective is a position I generally endorse, notwithstanding my awareness of its limitations, I do not believe that it is necessary for the courts to endorse a gender-specific approach in order to enact an understanding that women's responses to sexual harassment may be different than what men might do or what men might expect of women. Compare Kathryn Abrams, Gender Discrimination and the Transformation of 
text of sexual harassment trials would enhance women's ability to show pervasiveness or respond to evidence regarding their clothing or demeanor. It might also help to mitigate the cultural assumption that sexual harassment victims who do not directly confront their harassers do nothing to halt, interrupt, or indicate their displeasure with the offensive conduct. ${ }^{244}$

This strategy seems promising: it would emphasize women's partial agency in contexts where these showings would contribute to their legal victories. Yet this strategy is not without risk. Advocates might encounter difficulty in persuading courts to accept evidence of constrained resistance. Even if advocates were to succeed, for courts to accept new kinds of evidence of non-consent or unwelcomeness might further entrench the practice of gauging the behavior of the defendant by the response of the victim. It might delay that day when men become sufficiently disinvested in their sexualized conduct that they can consider the conduct itself rather than waiting for the woman's behavior to signal its problematic character. Moreover, the recognition of new kinds of showings might change the stance of those courts that have been willing to rest on the credibility of the plaintiff's claim of offense; these courts may hold women who have not mounted resistance to the standard of constrained resistance.

These dangers may be mitigated by interpreting these claims to express the pluralism of women's response that the sex radicals first highlighted. ${ }^{245}$ Recognizing women's partial agency does not mean that all women respond to sexual harassment, for example, with jocularity or avoidance: some women confront their harassers with explicit objections while others are too fearful to respond. Acknowledging partial agency means looking for responses outside the range of the autonomous liberal subject or the wholly dominated victim, responses consistent with the broad notion that women strive to affect their environments and direct their lives, even when their chances of doing so are limited by structures or relationships of oppression. If evidence of constrained resistance is viewed as part of a pluralism of women's responses, it may help to shift

Workplace Norms, 42 Vand. L. Rev. 1183, 1202-15 (1989) (advocating "reasonable woman" standard) with Kathryn Abrams, Social Construction, Roving Biologism, and Reasonable Women: A Response to Professor Epstein, 41 DePaul L. Rev. 1021, 1033-39 (1992) (detailing risks and drawbacks to "reasonable woman" standard). I believe, particularly after the Court's apparent endorsement of a gender-neutral perspective in Harris, 114 S. Ct. at 370-71, that this approach can be implemented under a genderneutral rubric of "reasonableness." For a fuller elaboration of this approach, see Kathryn Abrams, The Reasonable Woman: Sense and Sensibility in Sexual Harassment Law, Dissent, Winter 1995, at 48 [hereinafter The Reasonable Woman].

244. Cf. Roiphe, supra note 7, at 98 (discussing woman who nursed lier grudge but never objected to sexual harassment).

245. Mahoney's and Keller's work is cliaracterized by this pluralism and contextuality as well. See Keller, supra note 125, at 2231-32 (describing different ways in which women identify with subjects in pornography); Mahoney, supra note 156, at 19-24 (describing difference children make in battered women's calculations and strategies). 
the focus back to the conduct of the perpetrator. If women respond in a variety of ways to offensive sexualized conduct-a variety whose magnitude is only gradually becoming evident-it may seem less plausible to rely on any particular response to gauge the unacceptability of the conduct than to focus on the offensive conduct itself. ${ }^{246}$

246. This appears to be one consequence of the Court's decision in Harris to eliminate the "serious psychological injury requirement" in hostile environment sexual harassment cases: if the Court can no longer rely on one particular manifestation of injury on the part of the woman-if, impliedly, the Court recognizes that women's responses to sexual harassment can be plural-it will be more likely to look at the behavior of the alleged offender to gauge the inappropriateness of the conduct. See Harris, $114 \mathrm{~S}$. Ct. at 371; Abrams, The Reasonable Woman, supra note 243, at 51-54. Arguably this may be done more appropriately through the pluralization of the courts' notion of injury than through the pluralization of its notion of unwelcomeness or non-consent; but pluralization of victim response in these areas may serve a similar function.

A separate question is how agency critics should characterize women who equivocate in their resistance to their oppressive circumstances. The woman who equivocates in her resistance to her own oppression-the battered woman who repeatedly files and withdraws a complaint against her partner, for example-presents an interesting challenge to agency critics. This woman has not fared well under the current regime, in which dominancebased spousal abuse claims are injected into a liberally-oriented legal system. Theorists view her equivocation as a form of impaired judgment induced by her circumstances. See Mackinnon, supra note 17, at 147 (describing in both sympathy and detail ways in which women become complicit in their own subordination). Many segments of the bar, including some women lawyers, view such equivocation as an unacceptable source of uncertainty and frustration. See Lunchtime Colloquium on Family Law, Cornell Law School, Nov. 1990 (two female family law practitioners explain that they avoid cases involving battered women because the ongoing equivocation about whether to file or withdraw complaints injects unacceptable emotional tension and practical uncertainty into their professional hives). Would-or should-such a woman fare differently under the agency critique? Would agency critics counsel greater respect for the choices of this woman, describing her equivocation and her ultimate decision (in many cases) not to file charges against her batterer, as an expression of self-direction or authentic will?

In some respects, the position of the woman unable to commit to a complaint is analogous to the position of the sadomasochist or the lesbian butch or femme in the sex wars context: both are characterized under the dominance framework as women whose ostensibly self-directed choices actually replicate or reinforce the structures of their oppression. Agency critics can learn a great deal by considering the approach of the sex radicals to these embattled women. Some of the sex radicals were willing to characterize as authentic the desires of any transgressor of sexual taboos. See supra note 209 (describing sex radical writings on taboos, and sex radical writings advancing narratives of erotic progress as resting on notions of "authentic" or non-socially-constructed sexuality). Yet the best works of this period took a more nuanced approach. In her essay "The Fem Question," Joan Nestle considers the charge that the fem has willingly assumed the position of a "straight woman who is not a feminist." Nestle, The Fem Question, supra note 29, at 236. Exemplifying the careful, context-specific curiosity she describes as the "respect one life pays to another," id. at 234, Nestle highlights the ways that this claim is not borne out in her own life and the lives of other fems of the contemporary period. For example, responding to a listener's comment that Nestle's feminine style of dress made her easier to relate to, Nestle explains that this style of dress can only properly be understood when it is paired with the denim and leather of her female partner. See id. at 237. 
b. Revising Stigmatizing Imagery Within Dominance-Based Legal Claims. - A further strategy is to work within legal claims premised on dominance theory to mitigate or revise stigmatizing images that doctrine communicates about women victims. These images persist because, though present doctrines often require women to demonstrate strenuous resistance to unwanted sexual conduct, other features of the same doctrinesfeatures that determine what evidence is indicative of injury, or what characteristics in the claimant make her a "legitimate victim" - project images of women as wholly incapacitated by sexualized conduct. In interpreting or applying dominance-based legal claims, agency critics might reject requirements or approaches that characterize women as wholly compromised by oppression in favor of requirements or interpretations with the potential to demonstrate women's partial agency.

Mahoney herself pursued this strategy when she advocated changes in the feminist approach to battered women's self-defense. In this context, feminist advocates must identify a dynamic that constrained the woman defendant's ability to end her abuse without resort to violence. So they must, of necessity, show that her perceptions or her options were substantially compromised by her abuse. Yet, within this general mandate, Mahoney argues that feminist advocates can make choices that characterize the defendant as less, rather than more, incapacitated. Depicting a battering relationship as a struggle for power and control characterizes the woman as an actor seeking control, whose intentional, sometimes strategic, moves elicit responses from her partner. ${ }^{247}$ Identifying separation assault as a sub-species of spousal abuse highlights those situations in which women do try to exit abusive relationships, as well as the costs, in intensified violence, of many such attempts. ${ }^{248}$ Elizabeth Schneider has argued that the framing and presentation of expert testimony regarding "battered women's syndrome" can also make a difference in the image the testimony projects. She proposes offering the testimony of battered women's experts not simply to explain why women did not leave their abusive partners, but to demonstrate why their self-defense was "reason-

Nestle's honest curiosity and fact-specificity point the way to the approach an agency critic might take to understanding the inconstant resister. Although it is not always the case, there are times when the withdrawal of a complaint may represent a respectable exercise of a woman's agency: either because it is part of a pattern (resistance can be "partial" in terms of its constancy as well as its extent) that represents the best a particular woman can do at asserting herself under her circumstances, or because it reflects a contextually reasonable effort to strengthen a relationship or provide security for one's children. As dominance theorists have undertaken to detail the ways that women are coinplicit in their own subordination, agency critics might pursue such inquiries, informed by the possibility that this assumption of complicity is false.

For feminist characterizations of battered women's equivocation consistent with this analysis, see Christine A. Littleton, Women's Experience and the Problem of Transition: Perspectives on the Male Battering of Women, 1989 U. Chi. Legal F. 23, 43-47; Mahoney, supra note 156, at 36-39, 61-65.

247. See Mahoney, supra note 156 , at 53-60.

248. See id. at $61-71$. 
able."249 Offering expert testimony in connection with, or permitting courts to associate it exclusively with, failure to leave highlights the passivity or non-agentic characteristics of the woman in question. Associating such testimony with the reasonableness of the woman's self-defense calls attention to her thought processes and her efforts to preserve herself, 250 thereby underscoring her agency.

Recent developments in sexual harassment law point to a similar choice. In order to prevail on a hostile environment claim, a plaintiff must demonstrate, inter alia, that the conduct alleged was sufficiently hostile, intimidating, offensive, or abusive to create a hostile environment. ${ }^{251}$ To show this pervasiveness she must demonstrate some injury to herself or some impediment to her work performance. ${ }^{252}$ Yet, different ways of characterizing a plaintiff's injury may present her as more or less compromised by her sexualized treatment. This insight was brought home by the consideration and rejection in Harris $v$. Forklift Sys., ${ }^{253}$ of the requirement of "serious psychological injury."

Following precedent from several courts of appeals, the lower court in Harris required this showing of injury as a sine qua non of pervasiveness, and therefore recovery. ${ }^{254}$ This requirement communicated stigmatizing, compromised images of sexual harassment victims, not only because it suggested that the only legitimate victim of sexual harassment was the one who was brought to the brink of mental illness, but also because it implied that the plaintiff in the case, who had been able to confront

249. See Elizabeth M. Schneider, Describing and Changing: Women's Self-Defense Work and the Problem of Expert Testimony on Battering, 9 Women's Rts. L. Rep. 195, 200-08 (1986). Schneider's article was actually written several years before Mahoney's and anticipated, from a perspective informed by litigation as well as a scholarly interest, the tension between dominance-based depictions and depictions of women's agency that became the subject of academic discussion later. Although I tend to present this tension as a theoretical problem with urgent practical implications, this example and the life histories of the sex radicals suggest that this tension may have emerged first in women's lives and legal claims, only later to be addressed by theorists. For an endorsement of this approach as the proper direction for feminist theorizing, see Catharine A. MacKinnon, From Practice to Theory, Or What Is a White Woman, Anyway? 4 Yale J.L. \& Feminism 13 (1991).

250. See Schneider, supra note 249, at 220-222.

251. See Meritor Sav. Bank v. Vinson, 477 U.S. 57,67 (1993).

252. See id. at 64-68.

253. Harris v. Forklift Sys., Inc., 114 S. Ct. 367 (1993).

254. See Harris v. Forklift Sys., Inc., 1990 U.S. Dist. LEXIS 20115, at *14 (M.D. Tenn. Nov. 27, 1990). The most prominent case to reach this conclusion in an explicit manner was Rabidue v. Osceola Ref. Co., 805 F.2d 611, 620 (6th Cir. 1986), cert. denied, 481 U.S. 1041 (1987). But earlier cases, particularly those which sought to validate claims of emotional as opposed to economic injury had also emphasized the psychological wellbeing of the claimant. See Rogers v. EEOC, 454 F.2d 234, 238 (5th Cir. 1971), cert. denied, 406 U.S. 957 (1972) (racial harassment case stating that "[o]ne can readily envision working environments so heavily polluted with discrimination as to destroy completely the emotional and psychological stability of minority group workers ...."); see also Henson v. City of Dundee, 682 F.2d 897 (I Ith Cir. 1982). 
her employer about the conduct, was not a legitimate victim.255 In Harris, the Supreme Court reached a preferable resolution of this issue, ruling that there is no single showing that is necessary to establish the requisite pervasiveness-certainly not the showing that one has been completely mentally or emotionally compromised. ${ }^{256}$

Agency critics might press for a similar contextuality in doctrinal settings where they are called upon to characterize victims of sexualized injury. They might stress that women's behavior ${ }^{257}$ when they are targets of sexualized conduct differs, and that the category of legitimate victims includes those undominated enough to issue ultimata to the offender. ${ }^{258} \mathrm{~A}$ view of victimization emphasizing a pluralism of effects on the woman in question, and the presence within that pluralism of behavior denoting the capacity for self-direction, may continue to be necessary in the sexual harassment context. It may be used, for example, to prevent the Court from redefining the search for the wholly compromised victim as the search for a wholly compromised work product. ${ }^{259}$

This approach ${ }^{260}$ may be the most consistent with the insights of the agency critique. It is coupled, as is the critique, with the insights of the

255. See Anna Quindlen, Tied to the Tracks, N.Y. Times, Nov. 14, 1993, at A17.

256. See Harris, $114 \mathrm{~S}$. Ct. at 370 (noting that the protections of Title VII kick in long before the plaintiff has a nervous breakdown).

257. In using the term "response" here, 1 mean to indicate not simply women's contemporaneous reactions, or communication with the harasser, but also the ways in which the harassment affects them, and their work, over the longer run.

258. See Kathryn Abrams, Sexual Harassment at a Crossroads: Law and Culture in the Regulation of Sexual lnjury (1993) (unpublished manuscript, on file with the Columbia Law Review).

259. Justice Ginsburg may have sought to preempt this move when she framed the injury imposed by sexual harassment in terms of making it "more difficult" for women to do their jobs, rather than making it impossible for them to function. See Harris, $114 \mathrm{~S}$. Ct. at 372 (Ginsburg, J., concurring) (quoting Davis v. Monsanto Chemical Co., 858 F.2d 345, 349 (6th Cir. 1988), cert. denied, 490 U.S. 1110 (1989)).

260. One interesting and difficult question is whether abortion is a substantive area that could be addressed within the context of this approach. The posture of an abortion case is, of course, different because it is not individual male behavior that injures a woman, but state regulation that infringes her constitutional right to reproductive choice. The abortion context is also different in the sense that it is difficult to call the constitutional right to reproductive autonomy a dominance-based claim. Abortion rights were originally articulated within the framework of liberalism. In fact, I have previously observed that both legal doctrine and political discourse tend to characterize women as exercising unencumbered choice when they elect abortion; in fact they are, in many cases, constrained by the opinions or violence of, or potential for abandonment by, the men in their lives. See Kathryn Abrams, Ideology and Women's Choices, $24 \mathrm{Ga}$. L. Rev. 761 (1990). Nor am I the only feminist to suggest that abortion doctrine, even in its more protective phases, failed to take account of women's oppressive constraints. MacKinnon argued that the failure of Roe v. Wade, 410 U.S. 113 (1973), to frame women's protection in terms of women's sexual oppression or constraint laid the foundation for the later circumscription of the doctrine. See Catharine A. MacKinnon, Roe v. Wade: A Study in Male Ideology, in Abortion: Moral and Legal Perspectives 45 (Jay L. Garfield \& Patricia Hennessey eds., 1984). Moreover, with the contraction of the abortion right, it has become easier to see the tendency of the doctrine to turn a blind eye to the constraints 
dominance approach, yet it tempers the most rigid or exacting characterizations of that approach. It also recognizes, as does the critique, that much of the social work of law is performed indirectly, through the perpetuation of imagery rather than outcomes. ${ }^{261}$ Yet it has a drawback that is not likely to be present in the second strategy and that is not fully reflected in the examples given above: with the second strategy, mobilizing evidence of constrained resistance enhanced women's 'chances for legal recovery; with this strategy, offering evidence of women's continuing agency under oppression might have precisely the opposite effect. This threat is particularly acute with respect to spousal abuse. Here, courts are being asked to avert the imposition of criminal liability because of the defendant's impaired responsibility for her choices; the demonstration of partial agency may bring a defendant uncomfortably close to the "model responsible actor" whose features authorize the imposition of liability. ${ }^{262}$ While the stakes are lower, and the connection between agency and intervention is less obvious, this danger also inheres in cases in which women

women face in seeking to vindicate their reproductive rights. See, e.g., Harris v. McRae, 448 U.S. 297 (1980) (abortion funding cases); Maher v. Roe, 432 U.S. 464 (1977) (same).

The judicial restriction of the right to reproductive choice has now reached a point where courts' no longer simply turn a blind eye to women's constraints in securing abortions; they permit states actively to constrain women in reaching a decision about whether to abort. See Cohen, supra note 224, at 178-79. At this point it becomes possible to mount a dominance-based critique of the "undue burden" approach, which contains an agency-related strain germane to regulations that perpetrate subordinating imagery. Dominance theorists and agency critics might agree that constitutionally sanctioned statutory requirements such as waiting periods create a problem. Dominance theorists might reach this conclusion because such measures impose oppressive constraints on women's decisionmaking processes. See id. (criticizing Planned Parenthood v. Casey, 112 S. Ct. 2791, 2827-29 (1992) as permitting intrusion on women's deliberative reproductive autonomy). Agency theorists might object because these same statutory requirements depict women as so incapable of self-direction as to need state assistance in reaching their decision. But see Ruth Colker, Abortion \& Dialogue 116-19 (1992) (suggesting that state requirements that encourage more informed deliberation may respect and enhance women's decisionmaking capacity). While dominance theorists might be particularly alert to requirements that expose women to the risk of male violence, see Casey, $112 \mathrm{~S}$. Ct. at 2827-29 (striking down spousal notification requirement), they might generally conclude that other requirements such as waiting periods represent unjustified interference with women's reproductive deliberations. Agency critics might supplement this argument with the suggestion that such requirements project subordinated imagery damaging to women.

261. This approach does not embody the insight of the critique that the legal imagery influences social norms in plural, and often unpredictable, ways. But perhaps no prospective approach to the control or mobilization of legal imagery can effectively incorporate that insight. One might say that that insight is reflected, if at all, in the position I take in this section that the agency critique cannot be reduced in application to a single approach, and that critics must take a pragmatic and flexible approach to implementing their vision.

262. Cf. Coughlin, supra note 55, at 87-93 (difficulty in addressing battered women's self-defense under current dichotomous assumptions is that women either gain legal exoneration at the price of self-respecting representation, or depict themselves in selfrespecting ways at the price of having legal decisionmakers ascribe full responsibility to them for their violent actions). 
seek to impose criminal or civil liability on men for sexualized conduct. The claim for legal intervention to mitigate women's disadvantageous circumstances may appear to become more tenuous as the victim is characterized as increasingly capable of directing her course or securing her welfare. The impulse that motivated the lower court opinion in Harris is neither idiosyncratic nor limited to the area of sexual harassment law. In a legal system whose participants are still becoming accustomed to legal intervention to prevent or sanction sexualized injury, the partially agentic woman may be readily, and sometimes willfully, assimilated to the wholly autonomous subject whose self-regulable circumstances do not require legal intervention. This problem will be discussed in the following section.

3. Partial Agency and the Contraction of Legal Remedies - In applying their critique to the circumstances of women in the world, agency theorists will be obliged to do more than translate it into promising legal initiatives. They will be called upon to respond to questions both from those who are curious about its application and those who seek to undermine it by associating it with upalatable legal strategies. One such question was framed by the preceding discussion: is the agency critique consistent with a diminution of legal intervention on behalf of women? The proper response depends on the motivation or direction of the question and what precisely is meant by the "diminution of legal intervention." It is possible to identify at least three different versions of, or impulses behind, this question; each warrants different kinds of dialogic and programmatic moves.

This question might be inspired, for some, by a punitive or disciplinary response to women's partial efforts at self-assertion. The underlying assumption is that women's present status reflects an unspoken, chivalric bargain: Women acknowledge their social difference and political impotence in exchange for the personal and institutional solicitude of the more powerful. This ostensible bargain affects interactions ranging from the regulation of sex-based injuries to the opening of doors. The price of that protection or solicitude is that women conceive of or present themselves as powerless, or both-not responsible for their acts and impotent in avenging wrongs done to them. ${ }^{263}$ If women present themselves as competent or self-directed, this violates their half of the bargain: the depiction of women's partial agency thus becomes a basis for regulatory retrenchment. The purpose of this (proposed) retrenchment is to discipline women's departure from their socially prescribed role, and return all parties to the status quo ex ante.

A disciplinary impulse so starkly framed might be rare, although this impulse seems to inform the treatment of many sub-groups who exhibit "non-conforming" behavior-from Black single mothers to sexually ac- 
tive women. ${ }^{264}$ To those questioners who actually hold this impulse, a blunt response seems appropriate: such a bargain, if indeed it existed, would be patently unfair. Many groups secure legal protection of one kind or another without sacrificing their claims to self-direction. But the question about partial agency and legal retrenchment seems more likely to be animated by one of two other perspectives.

The question may arise from a view of the value of women's agency, on the one hand, and legal activism on gender issues, on the other, that is different from the one I espouse in this Part. My analysis of feminist critics of dominance theory should suggest that they hold many different views on these questions. The FACT Brief, in what I would describe as feminist good faith, characterized the MacKinnon-Dworkin Model AntiPornography Ordinance as imposing unnecessary protection, the stereotypic resonances of which undermined women's ability to mobilize on their own behalf. 265 Questioners could legitimately believe that protective legal intervention into historically private relations raises an inference of at least partially diminished capacity on the part of the beneficiary-be it a woman violated by pornography or a party to a contract of adhesion. They might, further, believe that women are in a particularly bad position to withstand such an inference, given that they may be assumed to be less capable of self-direction before the intervention occurs. Depending on one's view of the magnitude of the harm to be remedied, the strength of the negative inference likely to be raised by legal intervention, and the capacity of the affected group to manage the problem without legal intervention, one might legitimately arrive at a conclusion that women's agency is best served by contracting the scope of legal intervention.

While I respect such approaches, as the result of legitimate differences of (feminist) opinion, I do not agree with their thrust. My own vision of the agency critique positions it as a supplement to-an instrument for articulating a repressed element of - the dominance critique of a patriarchal social structure. I see it as an effort to highlight, and prevent legal interference with, the agency women exercise under oppression-an effort that nonetheless operates in the context of the broader goal of combatting women's oppression. Legal intervention is an essential tool of the latter struggle, both in its capacity to connect and mobilize many individual women, and in its ability to bring coercive power to bear on a set of practices and commitments that will not easily yield. So, while I recognize that other agency critics might analyze the choice differ-

264. See McClain, supra note 10, at 27-32 (discussing political and legal treatment of Black single mothers); infra Part IV.B.4 (discussing social and legal treatment of nonconforming groups of women).

265. See FACT Brief, supra note 56, at 131-32; text accompanying note 65 . 
ently, 266 I believe that agency critics should focus on those practical expedients that are, like the strategies illuminated at Part IV.B.2, consistent with a strong program of legal regulation of gender-specific injury. ${ }^{267}$

There is, however, another circumstance that might animate the question about the relation between partial agency and the contraction of legal intervention. It may be that this inverse relation, or trade-off, seems starker or more inevitable than it has to be because of a legal tendency to dichotomize both legal subjectivity and the necessity for legal intervention. The legal system as we presently know it may present a dearth of choices between agentic subjectivity paired with legally unconstrained action, on the one hand, and subordinated subjectivity paired with legally regulated action, on the other. Because of this dearth of conceptual options, people may infer from the agency critique that a contraction of legal intervention must be I) necessarily entailed, and 2) substantial in scope. To create other possibilities, agency critics may want to address this dichotomizing tendency directly.

4. Challenging Dichotomous Characterization of (Women's) Legal Subjectivity - The dichotomous characterization of women's legal subjectivity is a product of at least two influences. The first is a liberal tendency to assume a fully empowered, autonomous subject, and to acknowledge other possibilities only when the departure from this assumption is so sharp as to render the usual framework absurd. This somewhat reductive binarism is exacerbated in the case of women by an approach that heightens the dichotomy and often ascribes negative characteristics to women on both sides.

Linda McClain has argued that the legal tendency to dichotomize women's agency operates less as a description of actual lives than as a sanction for enforcing conformity with traditional gender roles and expectations. 268 She has observed, for example, that the paradigmatic dominance victim contrasts sharply with the culpable agency-or "irresponsibility" - of the unmarried, preguant Black teenager. ${ }^{269}$ This point can be readily generalized. Powerlessness is the description through which many legal proceedings simultaneously exonerate and stigmatize "good" victims of sexualized injury, those who conform to traditional gender roles. ${ }^{270}$ "Irresponsibility" - or full agency, culpably exercised-is the term with which legal authorities sanction non-conforming women:

266. See, e.g., Marcus, supra note 138 (regarding dominance feminism as problem rather than solution and relying primarily on individual action supplemented by background legal modification). IV.B.2.

267. This priority is reflected in my emphasis on approaches 2 and 3, supra Part

268. See McClain, supra note 10, at 28-29 (arguing that cultural stereotypes of single mothers as "irresponsible" reflect their deviation from expected norms of childrearing within marriage and women's dependence on men).

269. See id. at 30-36 (discussing Black single mothers).

270. See, e.g., Mary l. Coombs, Telling the Victim's Story, 2 Tex. J. Women \& L. 277, 286-93 (1993) (describing "plausible" stories in rape and sexual harassment cases). 
those who are sexually active, sexually aggressive, live outside the boundaries, or challenge the conventions of mainstream heterosexual family life. A similar form of policing is frequently accomplished by means of the dichotomy between the wholly autonomous subject and the wholly compromised victim. Assimilation to the image of the wholly compromised or constructed victim is a price that women may be asked to pay for legal intervention in interactions or circumstances that were formerly not the province of law. Women may assert their divergence from unremitting victimization, but only at the risk of being assimilated to the autonomous subject who does not require, or requires considerably less, legal intervention. Highlighting this disciplinary use of the dichotomy may help some legal decisionmakers question or revise it. But it is also important that those decisionmakers learn to see what exists on the human spectrum between those abstract poles: claimants who are functional and at least minimally self-directing, but also injured and in need of some degree of legal assistance.

One strategy may be to show that actual human lives are not confined to the dichotomous poles that they characteristically occupy in law. ${ }^{271}$ Beginning with a subject whose legal depiction is not so strongly implicated in a disciplinary effort may help legal decisionmakers to see that a dichotomous representation is neither widely accurate nor necessary to justify intervention. Battered women's advocates report, for example, that multifaceted representations of the batterer-as a troubled or threatening individual who is nevertheless "not a monster"-have been useful in encouraging legal decisionmakers to see battered women as persevering, sometimes dangerously, in bad relationships rather than as immobilized or pathologically passive. ${ }^{272}$

Another approach is to observe that, even in a legal system informed by liberal premises, the dichotomous characterization of subjectivity is less pronounced in substantive areas not directly related to gender. In using common-law claims as a frame for expanding legal protections of women, Jane Larson has highlighted doctrines that have traditionally described differences in agency between the wronged and wronging party

271. Many legal scholars have sought to highlight the complexities of human lives as a means of exposing the inadequacy of, or altering the content of, extant legal categories. This is at least part of the impulse behind the turn toward narrative in feminist and critical race scholarship. See generally Kathryn Abrams, Hearing the Call of Stories, 79 Calif. L. Rev. 971 (1991). Some legal scholars and litigators have sought to use this approach in the training of legal decisionmakers. See Martha Minow, Words and the Door to the Land of Cbange: Law, Language and Family Violence, 43 Vand. L. Rev. 1665, 1687-95 (1990) (describing Doing Justice Program at Brandeis University, in which legal educators use fictional narratives to educate judges about family violence).

272. See comment by Anne Shalleck, American University Legal Theory Workshop (Apr. 23, 1994); see also Christine A. Littleton, Women's Experience and the Problem of Transition: Perspectives on Male Battering of Women, 1989 U. Chi. Legal F. 23 (asking how analysis of domestic violence might be different if decisionmakers took seriously women's desire to preserve relationships, even with batterers). 
without making them subject to the stigma or even the degree of dichotomization that mark gender-based law. ${ }^{273}$ Such doctrinal areas may function as a model for a law that does not require thoroughgoing subordination in order to justify legal intervention and recovery.

Finally, the simplified liberal premises that underlie legal subjectivity may need to be revisited in accordance with more sophisticated accounts of liberal subjectivity or post-structuralist accounts of a decentered subject, who unproblematically juxtaposes agency with constraint. ${ }^{274}$ Investigating these alternative accounts of subjectivity may be a first step toward determining how they might be used to redirect or revise current legal assumptions.

*** *

Dominance feminism has sought to expose, in terms sufficiently stark to indict and galvanize, the systematic sexualized inequality that shapes our society and our law. Dominance feminists' critics have sought to vindicate the submerged or repressed elements of the dominance vision: the partial agency women retain and the sexual pleasure we might hope to enjoy as we struggle toward greater equality. By framing these two positions not as mutual antagonists but as parts of a single program whose elements are sometimes in sync and sometimes in tension, women can secure our future power without sacrificing the quality or misrepresenting the character of our present lives.

273. See, e.g., Larson, supra note 72 (advocating the creation of tort of seduction); Jane E. Larson, "Imagine Her Satisfaction": The Transformative Task of Feminist Tort Work, 33 Washhurn L.J. 56 (I993) (articulating feminism's goals in tort law).

274. In a recent work I have sought to explore how Title VII law might be modified through the attempt to accommodate a "complex" legal subject: one who combined multiple or seemingly contradictory characteristics, rather than fitting easily into the prescribed statutory categories. See Kathryn Abrams, Title VII and The Complex Female Subject, 92 Mich. L. Rev. 2479 (1994). Although this approach was applied to subjects who combined characteristics such as race and gender, or displayed qualities that occupied different poles of categorical dichotomy (that is, subjects who might be perceived as Black or as white, or biologically male and socially female), it might preview an approach to subjects who combine agency and constraint. 